\title{
A EFETIVAÇÃO DOS DIREITOS FUNDAMENTAIS ATRAVÉS DO PROCESSO COLETIVO: O ÂMBITO DE COGNIÇÃO DAS POLÍTICAS PÚBLICAS PELO PODER JUDICIÁRIO
}

Tese de Doutorado apresentada à Banca Examinadora da Faculdade de Direito da Universidade de São Paulo, como exigência parcial para a obtenção do título de Doutor em Direito, sob orientação do Prof. Dr. Kazuo Watanabe

FACULDADE DE DIREITO DA USP

SÃO PAULO

2009 
Banca Examinadora 
Ao Professor Kazuo Watanabe, pelas precisas orientações, sem as quais não seria possível o desenvolvimento deste trabalho. Mais do que isso, pelo amparo amigo nos momentos mais difíceis desta jornada. A minha eterna gratidão. 


\section{RESUMO}

O presente trabalho objetivou demonstrar que o processo coletivo é o instrumento adequado para a efetivação dos direitos fundamentais sociais. Com a renovação ética representada pela Declaração Universal dos Direitos Humanos, os Estados passaram a institucionalizar os direitos fundamentais, assegurando-lhes eficácia no plano jurídico. Os direitos fundamentais sociais foram concebidos para o estabelecimento da igualdade substancial e para a afirmação da democracia. A morfologia dos direitos fundamentais sociais destaca a existência de núcleos constitucionais de irradiação. Os direitos fundamentais sociais são plena e imediatamente eficazes. O Estado social define os contornos da teoria da separação de poderes. $\mathrm{O}$ controle de constitucionalidade erigiu o Poder Judiciário à condição de poder político. A independência e a imparcialidade dos órgãos jurisdicionais impedem a adoção de elementos externos à jurisdição, tais como as "questões políticas" e a "reserva do possível", para afastar o exame da violação dos direitos fundamentais sociais. O princípio da inafastabilidade obriga o exame judicial da violação dos direitos fundamentais sociais. A concessão de tais direitos em processos individuais causa o paradoxo da desigualdade. A análise das políticas públicas faz-se de forma distinta, consoante a fase processual. O âmbito de cognição das políticas públicas pelo Poder Judiciário está restrito à violação, por conduta comissiva ou omissiva do Estado, de direito fundamental social. Os direitos fundamentais sociais são o objeto do processo coletivo, e não as políticas públicas. $\mathrm{O}$ provimento jurisdicional realinha as políticas públicas e tende à satisfação plena e coercitiva dos bens da vida em âmbito geral.

Palavras-chave: Processo coletivo. Direitos fundamentais. Direitos fundamentais sociais. Eficácia. Poder Judiciário. Políticas públicas. Separação dos poderes. Questões políticas. Reserva do possível 


\begin{abstract}
This present work has tried to show that the collective process is the most suitable instrument to effectively implement fundamental social rights. Along with the ethical renewal represented by The Declaration of Universal Human Rights, States have started to institutionalize fundamental rights, securing an effective judicial plan. Fundamental social rights were conceived to establish a substantial measure of equality and affirm the tenets of democracy. The morphology of fundamental rights extenuates the irradiating constitutional nucleus. Fundamental social rights are straightforward and immediately effectual. The social State defines the Separation of Powers' Theory outlines. Constitutional control erected the power of the Judiciary, a requirement of political power. Independence and impartiality of the judicial organs impede the adoption of elements outside its jurisdiction, such as "political maters" and the "possible reserved rights", to remove the examination of the violation of fundamental human rights. The principle of irrevocability obliges the judiciary to examine the violation of fundamental rights. Concessions to these rights, paradoxically gives rise to inequality. The public policies' analysis was carried out in a distinct manner, in agreement with the procedural phase. The Judiciary's awareness of public policies is restricted to violations of a conduct of commission or omission, by the State, of fundamental social rights. The fundamental social rights are the objective of the collective process, and not public policies. The judicial arrangements realigned the public policies and takes complete and compelling satisfaction from life's offerings.
\end{abstract}

Keywords: Collective process. Fundamental rights. Fundamental social rights. Efficacy. Judiciary. Public policies. Separation of powers' theory. Political maters. Possible reserved rights 


\section{RIASSUNTO}

Il seguente lavoro ha come obiettivo dimostrare che il processo collettivo è lo strumento adeguato per l'effettività dei diritti fondamentali sociali. Con la rinnovazione etica rappresentata attraverso la Dichiarazione Universale de Diritti Umani, gli Stati passarono ad istituire $\mathrm{i}$ diritti fondamentali, garantendo efficacia nel piano giuridico. I diritti fondamentali sociali furono concepiti per la creazione dell'uguaglianza sostanziale e per l'affermazione della democrazia. La morfologia dei diritti fondamentali sociali distacca l'esistenza dei nuclei costituzionali di irradiazione. I diritti fondamentali sociali sono piena ed immediatamente efficaci. Lo stato sociale delimita i contorni della teoria della separazione dei poteri. Il controllo della consitutizionalità ha eretto il potere giudiziario alla parità del potere politico. L'indipendenza e l'imparzialità degli organi di giurisdizione impediscono l'adozione di elementi esterni alla giurisdizione, tali come le "questioni politiche" e la "riserva del possibili", per allontanare l'esame della violazione dei diritti fondamentali sociali. Il principio del non allontanamento obbliga l'esame Giudiziario della violazione dei diritti fondamentali sociali. La concessione di tali diritti in processi individuali causa il paradosso della disuguaglianza. L'analisi delle politiche pubbliche si fa di forma distinta, d'accordo con la fase processuale. L'ambito della cognizione delle politiche pubbliche da parte del potere Giudiziario è ristretto alla violazione, per condotta missiva od omissiva da parte dello Stato, di diritto fondamentale sociale. I diritti fondamentali sociali sono l'oggetto del processo collettivo, e non le politiche pubbliche. Il provimento giurisdizionale allinea le politiche pubbliche e tende alla soddisfazione piena e coercitiva dei beni di vita in ambito generale.

Parole chiave: Processo Collettivo. Diritti fondamentali. Diritti fondamentali sociali. Efficacia. Potere Giudiziario. Politiche pubbliche. Separazione dei poteri. Questioni politiche. Riserva del possibili 


\section{SUMÁRIO}

\section{CAPÍTULO I. O RECONHECIMENTO DA EFICÁCIA DOS DIREITOS}

FUNDAMENTAIS

1. Breve escorço histórico dos direitos humanos ...................................................... 11

2. O sistema ético de referência dos direitos humanos ..............................................17

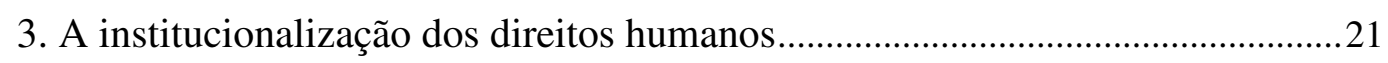

4. Natureza jurídica e alcance dos direitos fundamentais........................................25

5. Características relevantes para a tutela dos direitos fundamentais .....................27

6. A internacionalização dos direitos fundamentais: um sistema aberto e em

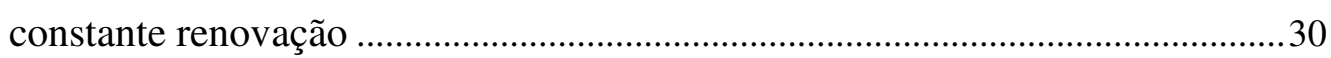

7. A exigência democrática de igualdade substancial....................................................

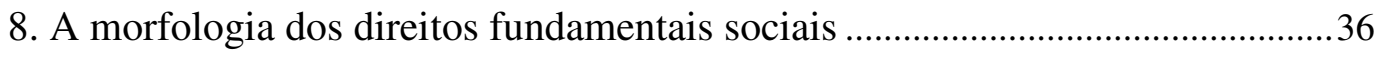

9. A satisfação espontânea dos direitos fundamentais sociais pelo Estado: as

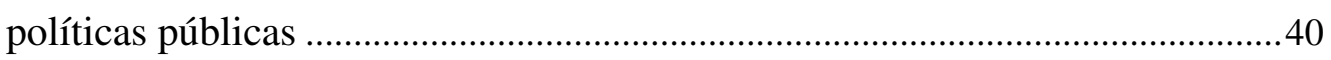

10. Abordagem sistêmica da eficácia dos direitos fundamentais sociais ................43

\section{CAPítulo II. CRISE ENTRE AS FORMAS DE EXPRESSÃo DO PODER ESTATAL: O PAPEL DO JUDICIÁRIO NA EFETIVAÇÃo DOS DIREITOS FUNDAMENTAIS SOCIAIS ..........................................48}

1. A teoria da separação dos poderes em Montesquieu 48

2. Reflexos da transição do Estado liberal para o Estado social na teoria da separação dos poderes.

3. O exercício do controle de constitucionalidade pelo Poder Judiciário: o início da discussão sobre a "judicialização da política".

4. A constitucionalização dos programas de ação do Estado..

5. Lesão causada aos direitos fundamentais sociais pelas omissões do Estado ....64

6. Alcance do art. $2^{\circ}$ da Constituição Federal de 1988 66

7. O papel do Poder Judiciário na efetivação dos direitos fundamentais sociais

7.1. A adoção do sistema ético de referência como pressuposto de atuação do Poder Judiciário 
7.2. Âmbito de atuação do Poder Judiciário no caso de lesão aos direitos fundamentais sociais

7.3. Impossibilidade de invocação do princípio da separação de poderes para a não-efetivação dos direitos fundamentais sociais.

7.4. A independência do Poder Judiciário e seus reflexos.

7.5. A legitimidade democrática dos juízes para a efetivação dos direitos fundamentais sociais

7.6. Inadmissibilidade da invocação do tema "reserva do possível" durante a fase cognitiva do processo .82

7.7. O perigo da autoneutralização institucional do Poder Judiciário. .86

7.8. Os desafios do Poder Judiciário no século XXI 88

\section{CAPÍtulo III. ÂMBITO DE COGNIÇÃo DAS POLÍTICAS PÚBLICAS NO PROCESSO COLETIVO}

1. Crise metodológica e desconsideração dos direitos fundamentais sociais como objeto de tutela no processo coletivo

2. Análise do princípio da inafastabilidade sob a ótica dos direitos fundamentais

3. O processo coletivo como instrumento para a efetivação dos direitos fundamentais

4. Peculiaridade dos direitos fundamentais sociais enquanto direitos difusos.... 113

5. Âmbito de cognição das políticas públicas pelo Poder Judiciário

5.1 Considerações preliminares sobre a análise das políticas públicas em duas fases processuais distintas

5.2. Os direitos fundamentais como o objeto do processo coletivo

5.3. O âmbito de cognição das políticas públicas

5.4. Características distintivas do provimento jurisdicional

5.5. Análise do princípio da proporcionalidade em matéria de direitos fundamentais sociais 


\section{INTRODUÇÃO}

A possibilidade de utilização da ação civil pública como instrumento de controle das políticas públicas tem causado grande perplexidade no mundo jurídico. A maior tergiversação ocorre nas hipóteses de omissão do Estado no cumprimento, por meio de políticas públicas eficazes, dos seus deveres constitucionais. Afirma-se, de modo geral, que o Poder Judiciário não pode interferir em assuntos de natureza política e que o impacto econômico no orçamento do Estado inviabiliza o exercício da atividade jurisdicional, não instrumentalizada para análises dessa magnitude.

O Poder Judiciário, embora vacile ante a imprecisão do princípio da separação de poderes, tem concedido, em casos extremos, tutela jurisdicional a determinados bens da vida amparados pela Constituição, tais como a saúde e a educação. Não há, contudo, um tratamento sistemático da matéria, de forma que a doutrina tem manifestado temor com a possibilidade da formação de um "governo de juízes" e com as consequências da transformação do Poder Judiciário no balcão de demandas sociais da população.

Em meio à discussão jurídica do assunto, assiste-se a um completo desrespeito dos entes públicos em relação aos direitos constitucionais dos cidadãos, fator que tem causado extrema miséria e incontida violência na sociedade. A abissal desigualdade existente entre os diversos setores da sociedade gera o ódio e o desespero, componentes altamente favoráveis à formação de governos totalitários, segundo nos relata a História. A democracia, valor tão caro à humanidade, encontra-se seriamente em risco quando o direito de votar é objeto de barganha por um pedaço de pão.

Tais os motivos que fazem do questionamento de Kazuo Watanabe um verdadeiro divisor de águas da ciência processual contemporânea. Afinal, qual o limite de intervenção nas políticas públicas por meio do processo de índole coletiva?

A resposta a essa indagação tem implicações importantíssimas no conceito de jurisdição, porquanto reavalia completamente as funções do Poder Judiciário no quadro da teoria da separação dos poderes e provoca inúmeros impactos na estrutura do processo coletivo. Mais do que isso, a solução da questão poderá permitir a abertura do processo às populações marginalizadas, erigindo-o em um dos instrumentos do Estado para a realização da democracia social. 
Lançamos nosso contributo à discussão com a proposição de uma nova metodologia. O objetivo do método é isolar os interesses e direitos difusos que se contrapõem às políticas públicas realizadas pelo Estado, extraindo, após a análise histórica de sua formação, a sua essência. Para tanto, será necessária a abstração de todos os instrumentos processuais atualmente existentes para a proteção dos interesses e direitos coletivos e difusos. O resultado será a reconstrução do instrumento através da detecção de sua gênese histórica próxima.

Deste modo, será realizado o estudo dos direitos fundamentais, desde a sua formação até a correlata institucionalização pelos Estados. Extrair-se-ão os caracteres distintivos desses direitos, analisando-se a sua morfologia, a fim de que, após uma reconstrução sistemática, possa-se estabelecer o alcance de sua eficácia jurídica.

Todavia, o mero reconhecimento da eficácia dos direitos fundamentais não é suficiente para a solução do problema proposto, porquanto a crise existente entre as formas de expressão do poder estatal ainda dificulta a sua aplicação pelo Poder Judiciário. Nesse sentido é que a teoria da separação dos poderes será reexaminada a partir da transição do Estado liberal para o Estado social. As conclusões obtidas permitirão o estabelecimento do exato alcance das atribuições do Poder Judiciário na consecução dos direitos fundamentais, especialmente os de segunda geração.

Admitindo-se que o Poder Judiciário exerce conduta pró-ativa na efetivação dos direitos fundamentais sociais - e essa é a nossa proposição fundamental -, imperioso que se estabeleçam os contornos da cognição das políticas públicas no processo coletivo. Estabelecidas as bases fundamentais para a atuação do Poder Judiciário no processo coletivo, podem ser fixados os limites de sua intervenção nas políticas públicas.

Este é o nosso aporte para a tentativa de ampliação das possibilidades de solução da questão proposta, por um novo ângulo de abordagem do tema. 


\section{CAPÍTULO I. O RECONHECIMENTO DA EFICÁCIA DOS DIREITOS FUNDAMENTAIS}

\section{Breve escorço histórico dos direitos humanos}

Na tentativa de alcançarem a gênese dos direitos fundamentais, os estudiosos apontam rudimentos de um trato universalista dos direitos inerentes aos seres humanos em textos tão antigos quanto o Código de Hamurabi e o Antigo Testamento, bem como em filosofias ancestrais, tais como o hinduísmo e o budismo. ${ }^{1}$ De fato, as características marcantes destas formas de expressão do pensamento são o universalismo no reconhecimento dos valores humanos e o estabelecimento do vínculo moral de sua observância.

Esta concepção coincide, à exceção do Código de Hamurabi, elaborado por volta do ano 1700 a.C., com o Período Axial ( $\pm 600-480$ a.C.), assinalado pelo pensamento de videntes do porte de Zaratustra, "Dêutero-Isaías", Buda, Pitágoras e Confúcio, no qual vicejaram os princípios fundamentais que influenciariam, até o presente, a conduta humana, e se estabeleceu a transição do misticismo para o pensamento filosófico. ${ }^{2}$

O Período Axial é assim denominado porque, dadas a contemporaneidade e a harmonia do pensamento daqueles videntes, bem como a enorme influência que exerceram sobre o pensamento mundial, constitui um eixo determinante na história humana. $\mathrm{O}$ estabelecimento do monoteísmo, encetado por "Dêutero-Isaías", o convite à subjugação do egoísmo, com consequente extinção do individualismo, e a exortação da luta pelo bem são elementos que ampliaram a percepção da realidade e importaram na transformação irreversível da conduta humana. ${ }^{3}$

A importância deste marco histórico reside exatamente na assunção, pelo homem, de um novo referencial, consubstanciado em um inequívoco modelo ético. Antes refém do misticismo e do medo que o subjugavam, passa o ser humano a considerar-se um

\footnotetext{
${ }^{1}$ ISHAY, Micheline R. The history of human rigths: from ancient times to the globalization era. Berkeley: University of California Press, 2008. p. 16-27.

${ }^{2}$ COMPARATO, Fábio Konder. A afirmação histórica dos direitos humanos. 3. ed. São Paulo: Saraiva, 2003. p. 8-11.

${ }^{3}$ TOYNBEE, Arnold. A humanidade e a mãe-terra. 2. ed. Rio de Janeiro: Zahar, 1982. p. 228-237.
} 
núcleo irradiante de valores universalmente reconhecidos. A violência e a arbitrariedade são contrastadas por valores éticos superiores de convivência humana.

O mesmo referencial ético foi desenvolvido na antiga filosofia grega, que explorava os valores da dignidade, da autonomia individual e da participação política, a ponto de alguns autores nela fundamentarem os direitos humanos. ${ }^{4}$

O conceito de um direito superior, não-criado pelos homens, foi alvo de menção expressa por Sófocles, em Antígona. Platão, em A República, embora não se refira à ideia de direitos humanos, invoca a capacidade racional do homem para interpretar a natureza do bem e aplicá-lo no exercício da vida em sociedade. ${ }^{5}$ Seu discípulo, Aristóteles, desenvolveu o conceito de política como desdobramento natural da ética para se alcançar a felicidade individual e coletiva. Em Política, o estagirita investiga as formas de governo e reconhece no homem um zoon politikon (animal político), condicionando a obtenção do bem maior - a justiça -, à constituição de uma verdadeira organização política, fundamentada na ética. ${ }^{6}$

Mas é o pensamento romano que, ao reconhecer o valor do homem, iniciará a construção da ideia de um direito natural, ${ }^{7}$ anterior ao direito dos homens e a ele superior. Este pensamento foi melhor sistematizado por Marcus Tullius Cicero em De legibus. Neste tratado filosófico, Cícero declara a existência de um princípio de justiça válido universalmente, comum a todos os homens, constante e eterno. ${ }^{8}$

Entretanto, por mais que se reconheça nas filosofias grega e romana o esforço para a construção de um paradigma ético na conduta humana, lastreado em princípios universais e imutáveis, fato é que a estrutura social daquelas culturas ainda estava muito radicada no sistema de referência arbitrário, restritivo e supressor dos direitos inerentes ao ser humano. É o caso, em Esparta, da situação dos ilotas, ou escravos, antigos habitantes das cidades dominadas, reduzidos às mais penosas condições de existência e cruelmente exterminados quando em número excedente. Mesmo Atenas, que no século V atingiu uma igualdade social e econômica sem precedentes, convivia com a escravidão. Em Roma, os

${ }^{4}$ GONÇALVES, William Couto. Gênese dos direitos humanos na antiga filosofia grega. Rio de Janeiro: Lumen Juris, 2007. p. 9-22.

${ }^{5}$ HAYDEN, Patrick. The philosophy of human rights. St. Paul, MN: Paragon House, 2001. p. 13-23.

${ }^{6}$ HAYDEN, Patrick. The philosophy of human rights, cit., p. 24-33.

${ }^{7}$ Sobre a via racional, através do direito natural, para a compreensão dos direitos humanos - valorização da natureza e do humano - estudos do impacto do conceito na religião: ROUSSEAU, Félicien. L'avenir dês droits humains. Canadá: Les Presses de l'Université Laval, 1996. 380 p.

${ }^{8}$ HAYDEN, Patrick. The philosophy of human rights, cit., p. 34-42. 
escravos não eram considerados seres humanos. Célebre é a história da destruição de Cartago, com a escravização dos poucos fenícios sobreviventes e o aniquilamento completo de sua cultura.

O cristianismo representou nova tentativa de evolução dos padrões éticos, ao sustentar a igual filiação divina de todos os homens. Jesus de Nazaré propõe o amor incondicional a Deus e a todas as pessoas como forma de conduta ideal (Mt, 5-7), afastando qualquer hipótese de discriminação ou violência contra o próximo. No evento conhecido como $O$ Sermão da Montanha, Jesus estabeleceu relevantes princípios éticos e espirituais, ${ }^{9}$ que exerceram grande influência sobre a consciência humana.

Através da obra de Paulo, um cristão judeu, o cristianismo absorveu as religiões regionais rivais e se expandiu a ponto de, ao lado da difusão do budismo mahayana, dar nova conformação à história da humanidade. ${ }^{10}$

O impacto do cristianismo na América Latina, como elemento propulsor na defesa dos direitos humanos, foi sentido, igualmente, na defesa dos direitos dos índios pela Igreja Católica, consoante as diretivas contidas no texto do Pastorale Officium, na bula Altitudo divino consillii e na encíclica Sublimis Deus, documentos fornecidos pelo papa Paulo III, entre 29 de maio e 2 de junho de 1537. ${ }^{11}$ A encíclica Sublimis Deus é considerada uma primeira declaração dos direitos humanos, reconhecendo no índio outro homem, com toda a extensão e defesa dos seus direitos.

No Brasil, era manifesta a intenção do governo de Lisboa de garantir formalmente os direitos dos índios segundo as leis do Reino. ${ }^{12}$ Dom Sebastião editou diversos diplomas, que objetivavam assegurar aos índios direitos inerentes à condição humana (leis de 1570, 1587, 1595, 1609, 1611, 1647, 1655 e 1680). Da mesma forma atuaram Pedro II, em 1680, e Dom José I, em $1755 .{ }^{13}$ A defesa intransigente dos direitos humanos pode ser constatada, ainda, nos trabalhos de Padre Antônio Vieira (1608-1697),

\footnotetext{
${ }^{9}$ LEWIS, John E. A documentary history of human rights: a record of the events, documents and speeches that shaped our world. New York: Carroll \& Graf Publishers, 2003. p. 100-106.

${ }^{10}$ TOYNBEE, Arnold. A humanidade e a mãe-terra, cit., p. 360-378.

${ }^{11}$ DE LA TORRE RANGEL, Jesús Antonio. Sobre el origen de la tradición hispanoamericana de los derechos humanos. Revista da Faculdade de Direito da Universidade Federal do Paraná, Curitiba, n. 29, p. 10-12, 1996.

${ }^{12}$ BRANDÃO, Adelino. Os direitos humanos: antologia de textos históricos. São Paulo: Landy, 2001. p. 13.

${ }^{13}$ BRANDÃO, Adelino. Os direitos humanos: antologia de textos históricos, cit., p. 14.
} 
de José Bonifácio, quando eleito deputado à Assembléia Nacional Constituinte de 1823, e de Joaquim Nabuco, em sua obra $O$ Abolicionismo. ${ }^{14}$

Nota-se, portanto, que os direitos humanos são o produto histórico da civilização ocidental, com raízes judaicas, greco-romanas e cristãs. ${ }^{15} \mathrm{O}$ reconhecimento de direitos inerentes a todos os seres humanos passa a ser reivindicado em um âmbito político-social cada vez maior.

Durante a baixa Idade Média, por volta do século XIII, São Tomás de Aquino, o mais famoso filósofo escolástico, proclamado filósofo oficial da Igreja, em 1879, por Leão XIII, definiu a lei como uma regra de conduta humana determinada pela razão. Aquino distinguiu, em a Summa Theologica (iniciada em 1265), quatro espécies de lei: a lei eterna, a lei natural, a lei divina e a lei humana. ${ }^{16}$ Entretanto, sustentava o Doctor Angelicus que a verdade somente seria alcançada com o uso integrado da razão e da fé, estabelecendo a competência exclusiva da Igreja nesta última matéria. Fé e razão, pois, ainda coabitavam.

Com a suplantação da filosofia escolástica, surge o Renascimento e o desenvolvimento do humanismo, que apelava para o homem universal. Também neste período da história se desenvolveu o conceito de direito natural. ${ }^{17}$

A percepção de um direito universal e imutável leva à inexorável necessidade de sua sistematização. $O$ que se busca agora é a justificativa racional de um direito reconhecido e exigível. Esta transição do pensamento filosófico para o plano jurídico é marcada pela cristalização do direito natural. Pode-se mesmo afirmar que o direito natural constitui a proto-história dos direitos fundamentais. ${ }^{18}$

O direito natural foi desenvolvido, de forma sistemática, por Hugo Grotius, no século XVII, cujas bases também fundamentaram o Direito Internacional. Hugo Grotius publicou De Juri Belli ac Pacis, em 1625, com o título elucidativo Libri tres in quibus Jus Naturae et Gentium item Juris publici praecipua explicantur. Suplantou os escolásticos da época, legando outras importantes obras do direito natural, como De Jure Praedae, de

\footnotetext{
${ }^{14}$ BRANDÃO, Adelino. Os direitos humanos: antologia de textos históricos, cit., p. 16-28.

${ }^{15}$ ALEXANDRINO, José de Melo. Direitos fundamentais: introdução geral. Estoril: Princípia, 2007. p. 9-10.

${ }^{16}$ HAYDEN, Patrick. The philosophy of human rights, cit., p. 43-47.

${ }^{17}$ TUCK, Richard. Natural rights theories: their origin and development. Cambridge: Cambridge University Press, 1979. p. 32-57.

${ }^{18}$ ANDRADE, José Carlos Vieira de. Os direitos fundamentais na Constituição Portuguesa de 1976. 3. ed. Coimbra: Almedina, 2006. p. 15.
} 
1604, e De Imperio Summarum Potestatum circa sacra, de 1614, mas publicado apenas em $1647 .{ }^{19}$

Samuel Pufendorf, pensador político que, respondendo a Grotius, a Hobbes e aos seus vários críticos, transformou a teoria da lei natural em uma disciplina independente, dominando a reflexão política até Kant. ${ }^{20}$ Pufendorf, em sua obra De officio hominis et civis juxta legem naturalem libri duo, de 1673, afirma que as vantagens que atendem à vida humana hoje derivam da mútua assistência entre os homens. E possuindo o homem consciência da necessidade de sua própria preservação, face à sua natureza belicosa, busca na lei natural a sociabilidade como forma de convivência pacífica. ${ }^{21}$

Para os defensores do direito natural, o homem é dotado de inteligência e é capaz de se autodeterminar. A natureza, segundo os jusnaturalistas, deriva de Deus. Existe, por outro lado, uma natureza humana, inerente a todos os homens. Por sua inteligência, o homem consegue extrair a lei não-escrita, a lei eterna, da própria sabedoria de Deus, contida em a natureza. Logo, há direitos que decorrem do simples reconhecimento da natureza humana, emprestando-lhe dignidade.

As várias filosofias dos direitos da pessoa humana repousam, pois, sobre a ideia de lei natural. ${ }^{22}$ A Escola do Direito Natural, neste passo, influenciou decisivamente o pensamento iluminista, lançando os fundamentos para a materialização das futuras Declarações. $^{23}$

John Locke sustentou que todos os homens são livres e iguais, contribuindo para a conjugação das ideias contidas na Declaração americana de $1776,{ }^{24}$ cujo artigo I é considerado o primeiro ato formal de reconhecimento dos direitos humanos. E tal se explica, pois a Magna Charta, de 1215, o Habeas Corpus Act, de 1679, e o Bill of Rights, de 1689, embora indicadores dos males do poder absoluto, objetivaram a proteção apenas de determinados estamentos. ${ }^{25}$ Locke, contudo, é considerado o último grande filósofo a

\footnotetext{
${ }^{19}$ DUFOUR, Alfred. Droits de l'homme, droit naturel et historie. Paris: Press Universitaires de France, 1991. p. 43-68.

${ }^{20}$ Cf. ELJATIB, Axel. Kant, Hegel y el principio del fin del derecho natural. Crítica Jurídica: revista latinoamericana de política, filosofia y derecho, n. 22, p. 185-223, 2003.

${ }^{21}$ PUFENDORF, Samuel. On the duty of man and citizen according to natural law. Trad. de Michael Silverthorne. Cambridge: Cambridge University Press, 1991. p. 34-35.

${ }^{22}$ MARITAIN, Jacques. Les droits de l'homme et la loi naturelle. Paris: Paul Hartmann, 1948. p. 61-84.

${ }^{23}$ FERREIRA FILHO, Manoel Gonçalves. Direitos humanos fundamentais. 9. ed. São Paulo: Saraiva, 2007. p. 10-11.

${ }^{24}$ BARRET-KRIEGEL. Blandine. Les drois de l'homme et le droit naturel. Paris: PUF, 1989. p. 73-87.

${ }^{25}$ COMPARATO, Fábio Konder. A afirmação histórica dos direitos humanos, cit., p. 48-49.
} 
tentar justificar racionalmente a escravidão, o que evidencia a contradição de seu pensamento, ao admitir a existência de homens que não dispõem da condição humana.

As obras de Grotius e Pufendorf, segundo a doutrina, influenciaram JeanJacques Rousseau, o autor de $O$ Contrato Social (1762). ${ }^{26}$ As ideias de Rousseau e de Charles-Louis de Secondat, o barão de Montesquieu, permeadas do voluntarismo jurídico do direito natural, igualmente projetaram reflexos sobre a Declaração dos Direitos do Homem e do Cidadão, de 1789.

Os ideais iluministas representaram uma reação à opressão e à arbitrariedade do antigo regime absolutista, efeitos de uma excessiva concentração do poder. Um novo padrão de ética foi sustentado pelos iluministas, a fim de que os direitos humanos pudessem ser ampliados e assegurados, mediante atos solenes de reconhecimento.

O esforço iluminista, todavia, não foi suficiente para aplacar o poder arbitrário. O novo imperialismo europeu, anelado às disputas territoriais e por mercados internacionais, contribuíram para a eclosão da Primeira Guerra Mundial (1914-1918), que causou a morte de cerca de dez milhões de pessoas. A Liga das Nações, organização internacional criada para assegurar a paz mundial, não conseguiu atingir seu objetivo, sendo dissolvida em 1942.

O forte sentimento nacionalista causado pelo Tratado de Versalhes (1919) recrudesceu o poder arbitrário, representado pelo nazismo e pelo fascismo. $\mathrm{O}$ fortalecimento do totalitarismo, decorrente de conjunturas socioeconômicas, e o antagonismo criado com os países democráticos deram início à Segunda Guerra Mundial (1939-1945).

Após seis anos de misérias, ódio e brutalidade, a humanidade pôde perceber o terrível sacrifício de vidas causado pela guerra. Os campos de concentração foram o palco macabro do mais aviltante aniquilamento dos direitos humanos. Carlo Cardia afirma, com toda a razão, que o nazismo e o holocausto constituíram o "inferno dos direitos humanos". ${ }^{27}$ A humanidade, enfim, percebeu que os direitos humanos ainda não estavam assegurados, sendo certo que o avanço da arbitrariedade no uso do poder representava séria ameaça à humanidade.

\footnotetext{
${ }^{26}$ BARRET-KRIEGEL. Blandine. Les drois de l'homme et le droit naturel, cit., p. 73.

${ }^{27}$ CARDIA, Carlo. Genesi dei diritti umani. 2. ed. Torino: G. Giappichelli, 2005. p. 120-132.
} 
$\mathrm{O}$ ato final de hecatombe dar-se-ia em agosto de 1945, em Hiroshima e Nagasaki, com a utilização do artefato atômico, momento no qual a humanidade percebeu que a sua sobrevivência estava em risco.

Como reação ética às atrocidades cometidas na Segunda Guerra Mundial, foi aprovada, em 1948, a Declaração Universal dos Direitos Humanos, sob o pálio da liberdade, da igualdade e da fraternidade, resgatando-se, assim, os ideais da Revolução Francesa.

\section{O sistema ético de referência dos direitos humanos}

A análise histórica dos direitos humanos revela que a sua concepção lastreia-se em basicamente dois sistemas de referência: ${ }^{28}$ o ético e o arbitrário. O primeiro reconhece no homem um centro de irradiação contínua de direitos não-suscetíveis de restrição, senão por consenso de toda a comunidade e com vistas à proteção do bem comum. O segundo, embora admitindo a irradiação destes direitos, concebe a possibilidade de restrição, quando não o seu mais completo aniquilamento, consoante o interesse arbitrário das forças políticas dominantes.

Não é por outro motivo que Gerhard Oestreich afirma que a tutela do homem contra o poder arbitrário é, na consciência pública, problema fundamental de nosso tempo. ${ }^{29}$ Com efeito, a partir do sistema de referência adotado, a concepção dos direitos humanos irá se alterar profundamente. E esta alternância é claramente verificada, no curso da história, nos diversos movimentos sociopolíticos que caracterizaram o uso do poder.

O Período Axial evidenciou que a ampliação do universo cognitivo dos homens contribuiu para o estabelecimento de toda uma nova estrutura cultural, anelada, essencialmente, aos altos valores humanos. O monoteísmo, peça fundamental daquele período, assentou a unidade de todos os homens. Esta unidade implica em absoluta igualdade e liberdade. A inteligência foi empregada para resolver o problema da perfeição moral dos homens, estabelecendo-lhes diretrizes de conduta. Liberdade e igualdade,

\footnotetext{
${ }^{28}$ TELLES JUNIOR, Goffredo da Silva. Direito quântico: ensaio sobre o fundamento da ordem jurídica. 7. ed. São Paulo: Juarez de Oliveira, 2003. p. 207-224.

${ }^{29}$ OESTREICH, Gerhard. Storia dei diritti umani e delle liberta fondamentali. Bari: Laterza, 2001. p. 7.
} 
portanto, passaram a constituir, segundo uma estrutura cultural modificada, bens soberanos da espécie humana. ${ }^{30}$

Trata-se do reconhecimento da dignidade da condição humana, cujo respeito observa um profundo referencial ético.

Entretanto, como bem assinalou o vidente, a sorte da verdade entre os homens é o esquecimento. O tempo se encarrega de subtrair das doutrinas o seu alcance ético, prevalecendo apenas o sentido formal. ${ }^{31}$ A verdadeira substância do conhecimento produzido no Período Axial não foi preservada, de sorte que o antagonismo entre o referencial ético e o referencial arbitrário no uso do poder serviu de palco para incontáveis atrocidades contra a humanidade durante o curso da história.

Jean Morange afirma que a superioridade absoluta do Estado, observada no fascismo, no nazismo e no stalinismo, objetiva a "despersonalização do ente humano". ${ }^{32} \mathrm{O}$ totalitarismo, pois, constitui a antítese dos direitos humanos, ou seja, o estabelecimento de um sistema arbitrário de referência, que desconsidera, segundo parâmetros particulares, o princípio da igualdade substancial.

Os homens de pensamento, entretanto, não deixariam o sentido ético dos direitos humanos desaparecer completamente, de forma a preservarem-se, durante ciclos históricos, os mais caros bens soberanos da humanidade. O direito natural representa a manifestação deste esforço de restauração do sistema ético de referência aplicado aos direitos humanos.

Direito natural é o direito fundamentado nos mais elevados padrões de ética, elemento que justifica racionalmente a sua legitimidade. ${ }^{33}$ Os direitos humanos, como produto inequívoco deste sistema ético de referência, detém legitimidade racional, superior e anterior à sua materialização no direito positivo. A legitimidade dos direitos humanos, por conseguinte, independe de sua positivação.

Laboram em equívoco, portanto, aqueles que sustentam ser a Declaração Universal dos Direitos Humanos mera recomendação dirigida aos membros da Assembléia

\footnotetext{
${ }^{30}$ TELLES JUNIOR, Goffredo da Silva. Ética: do mundo da célula ao mundo dos valores. 2. ed. São Paulo: Juarez de Oliveira, 2004. p. 238-242.

${ }^{31}$ BHAGAVAD-GîTÂ. A mensagem do mestre. Trad. Francisco Valdomiro Lorenz. São Paulo: Pensamento, 1993. cap. 4, n. 2, p. 55-56.

${ }^{32}$ MORANGE, Jean. Droits de l'homme et libertés publiques. 5. ed. Paris: Puf, 1985. p. 62-63.

${ }^{33}$ TELLES JUNIOR, Goffredo da Silva. Direito quântico: ensaio sobre o fundamento da ordem jurídica, cit., p. 324-325.
} 
Geral das Nações Unidas. Os direitos humanos são o produto de uma estrutura cultural ética, que estabelece a igualdade substancial como gênese de todos os valores. ${ }^{34}$ Não se trata da mera afirmação da existência de um direito universal ao nível de uma soberania em particular. Em verdade, os direitos humanos são o produto do reconhecimento expresso da existência de bens soberanos de toda a humanidade, cuja proteção é condição para a sua sobrevivência ${ }^{35}$ e para o seu aperfeiçoamento ético.

Desta forma é que o positivismo jurídico, conquanto reconheçamos sua grande contribuição para a Ciência, não poderá servir de óbice à efetivação dos direitos humanos. Não se trata, contudo, de contraposição ao positivismo jurídico ou da adoção do chamado direito livre. O que se propugna é o não-oferecimento de resistência à efetivação dos direitos humanos, sob o fundamento de que seu conteúdo esteja limitado ao direito positivo.

Os direitos humanos constituem o paradigma ético-jurídico de maior relevância para a humanidade. Esta percepção decorre da própria razão humana e do consenso global materializado na criação da Organização das Nações Unidas, em 26 de junho de 1945. Este ato demonstrou, de forma inequívoca, que se buscava construir um governo mundial do homem, fundamentado no respeito aos direitos humanos em todo o mundo. ${ }^{36}$

O consenso global sobre o reconhecimento dos direitos humanos é o passo inaugural para o estabelecimento da sua juridicidade plena. Os direitos humanos são legítimos, porque são éticos; e são jurídicos, porque fruto do consenso geral das nações. Falta-lhes, todavia, coerção, na medida em que esta somente pode ser garantida em toda a sua extensão através da soberania.

A ausência de coerção para a efetivação dos direitos humanos, desde que não expressamente positivados por um Estado, é fundamento positivista para que sejam desconsiderados do plano jurídico. Se o positivismo jurídico considera o Direito como ordem de coerção, ${ }^{37}$ não se harmonizariam os direitos fundamentais com o ordenamento jurídico. Seriam os direitos fundamentais, portanto, mera exortação de ordem moral.

\footnotetext{
${ }^{34}$ COMPARATO, Fábio Konder. A afirmação histórica dos direitos humanos, cit., p. 223-224.

${ }^{35}$ COMPARATO, Fábio Konder. A afirmação histórica dos direitos humanos, cit., p. 209-210.

${ }^{36}$ CARDIA, Carlo. Genesi dei diritti umani, cit., p. 151-160.

${ }^{37}$ KELSEN, Hans. Teoria pura do direito. Trad. João Baptista Machado. São Paulo: Martins Fontes, 2000. p. 33-66.
} 
Ocorre que, como assinalou Tércio Sampaio Ferraz Junior, a questão sobre o que constitua norma jurídica não é dogmática, mas sim zetética, ou seja, aberta. ${ }^{38}$ Desta forma é que se pode falar em norma-proposição, norma-prescrição ou normacomunicação. ${ }^{39}$ A concepção de Kelsen acerca do conceito de norma jurídica, portanto, além de reducionista, desconsidera o fenômeno jurídico que antecede a própria positivação do direito: o consenso ético sobre a obrigatoriedade da conduta. A norma, mesmo que ainda não-jurídica, pode ter caráter ético, indicativo e prescritivo. ${ }^{40}$

O conceito de soberania é meramente reflexivo ao conceito de direitos humanos. Do ponto de vista histórico, as Declarações americana (1776) e francesa (1789) foram iniciativas de determinados Estados, que evidentemente inspiraram alterações políticas em todo mundo. Todavia, foram iniciativas decorrentes do poder soberano dos povos americano e francês. Já a Declaração Universal dos Direitos Humanos (1948) representou a conjugação da vontade de várias soberanias sob uma ótica universalista. Os direitos humanos, por conseguinte, resultam, nesta quadra da história, da convergência de vontade das nações, com a expressa aceitação de sua validade jurídica em âmbito mundial.

Torna-se evidente que os próprios Estados aceitaram os fundamentos da Declaração Universal dos Direitos Humanos como sistema ético de referência de toda a sua legislação, inclusive no que tange às respectivas normas fundamentais. Isto significa que, em uma hipótese, meramente argumentativa, de normatividade zero, na qual inexistissem quaisquer normas nos Estados pactuantes, o parâmetro ético-normativo fundamental para a sua criação seriam as normas descritivas dos direitos humanos.

Os movimentos contínuos de positivação dos direitos humanos, tal como acordado pelas nações soberanas, implementaram, gradualmente, os mecanismos coercitivos característicos de cada Estado, precipitando o conteúdo ético-jurídico dos direitos fundamentais.

Diante deste fenômeno, é impossível ao jurista não reconhecer nos direitos humanos conteúdo normativo e vinculante, posto que constituem comandos capazes de

\footnotetext{
${ }^{38}$ FERRAZ JUNIOR, Tercio Sampaio. Introdução ao estudo do direito: técnica, decisão, dominação. São Paulo: Atlas, 1988. p. 99.

${ }^{39}$ FERRAZ JUNIOR, Tercio Sampaio. Introdução ao estudo do direito: técnica, decisão, dominação, cit., p. 100-101.

${ }^{40}$ TELLES JUNIOR, Goffredo da Silva. A criação do direito. 2. ed. São Paulo: Juarez de Oliveira, 2004. p. 475-479.
} 
alterar até mesmo as normas fundamentais dos Estados, ainda que apenas por iniciativa própria destes últimos.

Se o sistema de referência é condição do conhecimento, ${ }^{41}$ conclui-se que o exato alcance do conceito de direitos humanos somente será atingido caso se adote um irrestrito parâmetro ético de referência. Sob este ângulo de análise, os direitos humanos constituem a ética no direito em grau máximo, assegurando a realidade espiritual ${ }^{42} \mathrm{e}$ histórico-cultural dos valores mais caros à humanidade. Em nenhuma hipótese poder-se-á admitir o arbítrio como sistema de referência na compreensão dos direitos humanos, porque incompatível com o sistema ético adotado pelas diversas soberanias.

O sistema ético de referência terá fundamental importância no processo de efetivação dos direitos fundamentais no plano interno dos Estados, a partir de sua institucionalização.

\section{A institucionalização dos direitos humanos}

A institucionalização dos direitos humanos ${ }^{43}$ é o consectário lógico-jurídico da Declaração Universal dos Direitos Humanos, e permite agregar aos valores éticos a força normativa da Constituição. ${ }^{44}$ Representa a implementação formal, pelos Estados, do novel sistema ético de referência, mediante a adequação de suas normas constitucionais internas ao novo modelo. ${ }^{45} \mathrm{O}$ vocábulo "institucional" revela uma forma de linguagem que traduz a consciência jurídica do momento histórico e repousa no conteúdo ético que lhe emprestamos. $^{46}$

\footnotetext{
${ }^{41}$ TELLES JUNIOR, Goffredo da Silva. Direito quântico: ensaio sobre o fundamento da ordem jurídica, cit., p. 221.

${ }^{42}$ REALE, Miguel. Filosofia do direito. 19. ed. São Paulo: Saraiva, 2002. p. 699-706.

${ }^{43}$ Segundo CAPPELLETTI e TALLON, a tendência de considerar certos direitos válidos além dos limites do espaço e do tempo - universais e eternos - mostraram-se utópicos, porque os mesmos direitos são mutáveis com as circunstâncias da história e da sociedade. $\mathrm{O}$ declínio das concepções do direito natural instaurou a tendência de positivação de certos direitos e a sua constitucionalização, neste último caso como forma de aumentar sua efetividade. Cf. CAPPELLETTI, Mauro; TALLON, Denis. Fundamental guarantees of the parties in civil litigation. Milano: Giuffrè, 1973. p. 664-667.

${ }^{44}$ Cf. HESSE, Konrad. A força normativa da Constituição. Trad. Gilmar Ferreira Mendes. Porto Alegre: Sergio Fabris, 1991. p. 20 e s.

${ }^{45}$ Ao expor as cinco "leis do poder", Adolf BERLE esclarece que a instituições, destinadas ao exercício do poder, são "invariavelmente baseadas em uma filosofia ou em um sistema de ideias" (BERLE, Adolf A. The three faces of power. New York: Harcourt; Brace \& World, 1967. p. 3-10).

${ }^{46}$ SANCHES VIAMONTE, Carlos. Constitucionalismo: sus problemas. Buenos Aires: Bibligrafica Argentina, 1957. p. 37-42.
} 
A institucionalização dos direitos humanos já ocorrera em outros momentos históricos, a partir das Declarações americana e francesa. Desde então, diversas constituições passaram a positivar os direitos humanos, estabelecendo-lhes conteúdo normativo. Ocorre que, a partir de 1948, os direitos humanos sofreram uma restauração ética intensa, de forma que um novo sistema de referência foi implantado.

O que se altera no panorama jurídico interno dos Estados é o novo referencial ético, consubstanciado no consenso das diversas nações. Os direitos humanos, portanto, passam a ter uma nova compreensão, lastreada no compromisso ético de progressiva e absoluta proteção ao nível mundial. Assim, a expansão internacional, com a consequente institucionalização, constitui mecanismo que objetiva a efetiva proteção dos direitos humanos. $^{47}$

É por esta razão que os direitos humanos positivados anteriormente a 1948 não podem mais ser interpretados à luz de conceitos ultrapassados e despidos do novo sistema ético de referência. Não é mais possível, exemplificativamente, a conjugação dos direitos humanos com postulados puramente liberais, porquanto o modelo de solidariedade contido no novo paradigma ético exige a distributividade de recursos para que se atinja o bem comum. Como consequência, as prestações estatais para a efetivação dos direitos fundamentais devem ser negativas e positivas, o que não se concebia no Estado liberal.

Toda a interpretação que se dê aos direitos humanos deve basear-se em um sistema ético de referência, extraído dos princípios contidos na Declaração dos Direitos Humanos. Os anteriores modelos positivados de direitos humanos que não guardarem harmonia como o novo sistema ético de referência contrariam a vinculação universal característica daqueles direitos. ${ }^{48}$ Tais modelos demandam redimensionamento pelos aplicadores do direito, a fim de que não remanesçam resquícios do referencial arbitrário.

Por conseguinte, a interpretação dos direitos humanos deve, invariavelmente, realizar-se em conformidade com a ética.

O estabelecimento de uma norma ética universal, decorrente da submissão voluntária das nações, todavia, parece não ser suficiente para a captação de todo o seu conteúdo jurídico-normativo. Como observa Gérard Conac, a justiça, para os juristas, tem um sentido mais técnico, institucional, lastreado em realidades sociais e influências

\footnotetext{
${ }^{47}$ ISHAY, Micheline R. The history of human rigths: from ancient times to the globalization era, cit., p. 178 e s.

${ }^{48}$ A expressão é utilizada por ALEXANDRINO, José de Melo. Direitos fundamentais: introdução geral, cit., p. 33-36.
} 
ideológicas e preparado pelo processo histórico. ${ }^{49}$ Mesmo que a Declaração Universal dos Direitos Humanos exprima elevados padrões de ética e de justiça, os operadores do direito, em especial os afiliados ao sistema romano-germânico ${ }^{50}$, necessitam de normas positivadas, norteadoras de condutas, para a integralização do sistema.

Um dos aspectos importantes da institucionalização dos direitos fundamentais é a necessária delimitação territorial para o exercício da força coativa do Estado. Delimitado o território, imediatamente os direitos fundamentais passam a fazer parte integrante do ordenamento jurídico estatal, o que permite a sua sistematização. Os direitos humanos, então, revestem-se da indispensável força coercitiva, necessária para a sua plena efetivação no plano material, o que os torna autênticos direitos subjetivos. ${ }^{51}$

Segundo José de Melo Alexandrino, a institucionalização dos direitos humanos passou por quatro linhas interdependentes durante a passagem dos Estados absoluto, préconstitucional e constitucional, a partir do século XIII: a) a positivação dos direitos fundamentais em Constituições escritas, formais e rígidas, b) o reconhecimento de novos direitos (as novas "gerações" de direitos fundamentais), c) a transição do Estado liberal para o Estado social d) e o aperfeiçoamento dos sistemas jurídicos de efetiva tutela dos direitos fundamentais. ${ }^{52}$

A institucionalização dos direitos humanos, em Constituições escritas e rígidas, objetiva conferir-lhes proteção máxima ao nível dos Estados. ${ }^{53}$ Uma vez inseridos nas Constituições, os direitos humanos, dotados de pretensão universalista e de dimensão fundadora das comunidades humanas, assumem a forma de direitos fundamentais, constitucionalmente positivados e juridicamente garantidos. ${ }^{54}$ Os direitos fundamentais,

\footnotetext{
${ }^{49}$ CONAC, Gérard. Justice et Constitutions. In: CONAC, G.; DELPÉRÉE, F.; PACTET, P.; TURPIN, D. Constitution et justice. Tunis: Presses del L’Université des Sciences Sociales de Toulouse; Académie Internationale de Droit Constitutionnel, 1995. p. 12-13.

${ }^{50} \mathrm{Cf}$. DAVID, René. Os grandes sistemas do direito contemporâneo. Trad. Hermínio A. Carvalho. São Paulo: Martins Fontes, 1998. p. 25 e s.

${ }^{51}$ TELLES JUNIOR, Goffredo da Silva. Direito quântico: ensaio sobre o fundamento da ordem jurídica, cit., p. 316-318.

${ }^{52}$ ALEXANDRINO, José de Melo. Direitos fundamentais: introdução geral, cit., p. 14-16.

${ }^{53}$ Segundo adverte Antonio E. Perez LUÑO, há um intercâmbio entre a Constituição e os direitos humanos. Os instrumentos normativos constitucionais garantem os direitos fundamentais. Por outro lado, a permanência dos direitos humanos na Constituição é garantia da identidade do texto constitucional, de tal forma que eventual alteração no estatuto daqueles direitos poderá sinalizar a substituição da própria Constituição (PEREZ LUÑO, Antonio E. Los derechos fundamentales. Madrid: Tecnos, 1984. p. 68-69).

${ }^{54}$ CANOTILHO, José Joaquim Gomes; MOREIRA, Vital. Constituição da República Portuguesa anotada. 4. ed. Coimbra: Coimbra Ed., 1978. v. 1, p. 240.
} 
portanto, são os direitos humanos constitucionalizados e, agregados à Constituição, assumem uma posição de alta relevância no sistema de direitos subjetivos. ${ }^{55}$

A consagração constitucional dos direitos fundamentais, tornando-os direitos constitucionais, assenta a limitação do poder estatal. ${ }^{56} \mathrm{O}$ limite ao poder é traçado pela realização efetiva dos direitos fundamentais, interpretados em conformidade com a ética. Logo, qualquer ato produzido pelas formas de expressão do poder estatal estará limitado pelo princípio da efetivação dos direitos fundamentais, decorrente do sistema ético de referência. $^{57}$

Positivados os direitos fundamentais, permanece íntegro o sistema ético de referência, de tal forma que a restrição ou a supressão destes direitos constitui indisfarçável violação da norma ética universal e do acordo internacional de submissão. Esta violação permite, inclusive, a responsabilização do Estado no domínio internacional, ante o fenômeno da relativização da soberania, característico do processo de internacionalização dos direitos humanos. ${ }^{58}$

Não basta, portanto, aos Estados institucionalizarem os direitos fundamentais. Devem, consoante o modelo escolhido através do consenso internacional, efetivá-los segundo os mais altos parâmetros éticos, a fim de que se atinja uma harmonização universal da dignidade humana. As vicissitudes político-partidárias, mesmo sustentadas em pressupostos econômicos, que restrinjam ou suprimam direitos fundamentais, fatalmente estarão vinculadas a um sistema arbitrário de referência e, por consequência, violarão a Constituição e a ordem internacional. ${ }^{59}$

Para que não haja violação do compromisso internacional, o Estado deve, mediante mecanismos jurídicos próprios inseridos em sua Constituição, desenvolver um autocontrole de seus atos. Em última análise, contudo, a violação será sempre de um direito fundamental. Todo ato que cause uma lesão a direito fundamental estará, pois,

\footnotetext{
${ }^{55}$ ROCHA, José de Albuquerque. Estudos sobre o Poder Judiciário. São Paulo: Malheiros Ed., 1995. p. 5759.

${ }^{56}$ ANDRADE, José Carlos Vieira de. Os direitos fundamentais na Constituição Portuguesa de 1976, cit., p. 20-25.

${ }^{57}$ Ver supra, Item 2.

${ }^{58}$ PIOVESAN, Flávia. Direitos humanos e o direito constitucional internacional. 8. ed. São Paulo: Saraiva, 2007. p. 117 e s.

${ }^{59}$ Expressiva é a lição de Paulo BONAVIDES: "Os direitos fundamentais são a bússola das Constituições. A pior das inconstitucionalidades não deriva, porém, da inconstitucionalidade formal, mas da inconstitucionalidade material, deveras contumaz nos países em desenvolvimento ou subdesenvolvidos, onde as estruturas constitucionais, habitualmente instáveis e movediças, são vulneráveis aos reflexos que os fatores econômicos, políticos e financeiros sobre elas projetam" (BONAVIDES, Paulo. Curso de direito constitucional. 13. ed. São Paulo: Malheiros Ed., 2003. p. 600-601).
} 
sujeito a controle, uma vez que a atuação estatal vincula-se à Constituição. ${ }^{60}$ As lesões, por outro lado, podem decorrer de conduta comissiva ou omissiva do Estado, gerando, como consequência, a obrigação de realizar prestações negativas ou positivas.

Desta forma, é indispensável que se identifique a natureza jurídica dos direitos fundamentais, delimitando-se as relações existentes entre o cidadão e o Estado.

\section{Natureza jurídica e alcance dos direitos fundamentais}

Os direitos fundamentais, por estarem inseridos no texto de uma Constituição, são direitos constitucionais. ${ }^{61}$ A Constituição, portanto, vincula o Estado à efetivação dos direitos fundamentais, surgindo deste vínculo uma situação jurídica. ${ }^{62}$ Decorre desta afirmação que entre o Estado e o titular dos direitos fundamentais há uma relação jurídica de direito público. Para Niklas Luhmann, a relação existente é obrigacional, na qual o cidadão é titular de um direito subjetivo, e o Estado, o sujeito desta obrigação. ${ }^{63}$

Como observa Michelangelo Bovero, as pretensões morais, após se converterem em direito, deixam de ser simples pretensões, para se tornarem verdadeiros direitos. ${ }^{64}$ Os direitos fundamentais são, pois, autênticos direitos subjetivos. ${ }^{65}$ Por estarem amparados pela Constituição, os direitos fundamentais são direitos subjetivos constitucionais, de forma que, em caso de lesão, decorrente de conduta do Poder Público ou de particulares, nasce para o titular uma pretensão a ser exercitada mediante o direito de ação. $^{66}$

${ }^{60}$ ALEXANDRINO, José de Melo. Direitos fundamentais: introdução geral, cit., p. 33-36.

${ }^{61}$ SILVA, José Afonso da. Curso de direito constitucional positivo. 24. ed. São Paulo: Malheiros Ed., 2005. p. 180.

${ }^{62}$ ALEXANDRINO, José de Melo. Direitos fundamentais: introdução geral, cit., p. 20-28.

${ }^{63}$ LUHMANN, Niklas. I diritti fondamentali come istituzione. Trad. Stefano Magnolo. Bari: Dedalo, 2002. p. 301.

${ }^{64}$ BOVERO, Michelangelo. Derechos fundamentales y democracia em La teoria de Ferrajoli: un acuerdo global y una discrepancia concreta. In: FERRAJOLI, Luigi; BACCELLI, Luca; BOVERO, Michelangelo; GUASTINI, Riccardo; JORI, Mario; PINTORE, Anna; VITALE, Ermano; ZOLO, Danilo. Derechos fundamentales y democracia en Ferrajoli. 3. ed. Madrid: Trotta, 2007. p. 225.

${ }^{65}$ Cf. CANOTILHO, José Joaquim Gomes. Direito constitucional. 6. ed. Coimbra: Almedina, 1993. p. 535 e s; ALEXY, Robert. Teoria de los derechos fundamentales. Trad. Ernesto Garzón Valdés. Madrid: Centro de Estudios Constitucionales, 1997. p. 173 e s. Cf., ainda, DUARTE, Clarice Seixas. O direito público subjetivo ao ensino fundamental na Constituição Brasileira de 1988. 2003. Tese (Doutorado) - Faculdade de Direito, Universidade de São Paulo, São Paulo, 2003.

${ }^{66}$ BARROSO, Luís Roberto. Curso de direito constitucional contemporâneo: os conceitos fundamentais e a construção do novo modelo. São Paulo: Saraiva, 2009. p. 221-222. 
Sob o prisma da teoria institucional, os direitos fundamentais são compreendidos como complexos normativos, que devem ser protegidos pelo Estado. ${ }^{67}$ Uma vez institucionalizados, os direitos fundamentais produzem um efeito potencial de irradiação para todo o ordenamento jurídico, vinculando a atuação das formas de expressão do poder estatal. ${ }^{68}$

Os atos legislativos, administrativos e judiciais, por conseguinte, devem ser produzidos em conformidade com o princípio de efetivação dos direitos fundamentais, mediante "impulsos" e "diretivas de atuação". ${ }^{6}$

O efeito de irradiação dos direitos fundamentais é de tal forma intenso, que vincula a conduta do Estado. Isto significa que as formas de expressão do poder estatal devem atuar coordenadamente para que se efetivem os direitos fundamentais. Assim, o Estado, por seus agentes, ao não produzir a irradiação necessária para a efetivação dos direitos fundamentais, viola a Constituição.

Não basta, todavia, que a irradiação dos direitos fundamentais opere em sentido meramente formal. É indispensável que todos os direitos fundamentais sejam concretizados da forma mais ética e substancial possível. A mera consignação do direito à saúde no texto da Constituição é insuficiente para a sua efetiva proteção. Faz-se necessário que este comando se irradie materialmente, mediante a prática, pelo Estado, dos atos necessários para que o bem da vida saúde esteja à disposição do cidadão.

Os direitos humanos são efetivados, portanto, no momento em que atingem a irradiação máxima prevista na Constituição, mediante a prática de todos os atos formais e materiais necessários para o desfrute, pelo seu titular, do bem da vida.

Há, portanto, lesão ao direito fundamental quando o seu titular não dispuser do bem da vida previsto na norma constitucional. A mera previsão abstrata do direito fundamental, sem a concessão material do bem da vida, implica igualmente em lesão e, portanto, sujeita o Estado à obrigação de satisfazê-lo.

Este fenômeno se explica a partir do sistema ético de referência.

\footnotetext{
${ }^{67}$ NOVAIS, Jorge Reis. As restrições aos direitos fundamentais não expressamente autorizadas pela Constituição. Coimbra: Coimbra Ed., 2003. p. 47-125.

${ }^{68}$ NOVAIS, Jorge Reis. As restrições aos direitos fundamentais não expressamente autorizadas pela Constituição, cit.

${ }^{69}$ NOVAIS, Jorge Reis. As restrições aos direitos fundamentais não expressamente autorizadas pela Constituição, cit.
} 
Os direitos fundamentais, como já afirmado, ${ }^{70}$ constituem os bens soberanos da humanidade. Anelando-se o Estado ao sistema ético de referência, seu compromisso internacional é o de concretizar os direitos fundamentais. Caso o Estado estabeleça a existência de determinado direito fundamental, mas não satisfaça o respectivo bem da vida, estará criando, por seu puro arbítrio, um impasse na realização deste direito. Se ética é a "ordenação destinada a conduzir o homem de acordo com seus bens soberanos", 71 então o Estado violou o seu compromisso internacional pela inobservância do sistema ético de referência.

De acordo com o exposto, os direitos fundamentais somente serão efetivados se o Estado adotar um sistema ético de referência tendente à contínua consecução dos bens da vida mais caros à humanidade, os bens soberanos. A assunção, pelo Estado, de um sistema arbitrário de referência representa lesão ao direito subjetivo constitucional, passível de correção no plano interno pela via jurisdicional.

A responsabilização internacional, efeito desta lesão, não será objeto de nossa análise.

\section{Características relevantes para a tutela dos direitos fundamentais}

Os direitos fundamentais são plenamente exigíveis. Entretanto, dada a peculiaridade de sua conformação dogmática, ${ }^{72}$ possuem determinadas características que os tornam extremamente complexos, o que de certa forma dificulta a exata percepção do campo de abrangência de sua eficácia.

O extenso rol de direitos fundamentais declinado nas Constituições bem revela o âmbito de atribuições e atividades que o Estado assume para a sua efetivação. É imprescindível, portanto, que sejam eleitas características relevantes para a defesa dos direitos fundamentais, distinguindo-os dos demais direitos e das inúmeras atribuições estatais. Esta metodologia objetiva sistematizar a atuação estatal em matéria de direitos

\footnotetext{
${ }^{70}$ Vide supra, p. 7.

${ }^{71}$ TELLES JUNIOR, Goffredo da Silva. Ética: do mundo da célula ao mundo dos valores, cit., p. 249.

${ }^{72}$ CANOTILHO, José Joaquim Gomes. Direito constitucional, cit., p. 495 e s.
} 
fundamentais, mas sob a ótica de uma eventual tutela jurisdicional, não esgotando as classificações doutrinárias sobre a matéria. ${ }^{73}$

Resultam os direitos fundamentais do consenso internacional e sua institucionalização é o produto do compromisso expressamente assumido pelas diversas soberanias. Logo, os direitos fundamentais são direitos universais, de titularidade de todos os seres humanos, na extensão conferida pelo consenso internacional.

Os direitos humanos são atributos inerentes à condição humana e não de uma nacionalidade em particular. A restrição dos direitos humanos pelo Estado seria ilógica, ${ }^{74}$ portanto, e, acima de tudo, antiética. Os Estados, por consequência direta desta característica, não podem restringir os direitos fundamentais a rol inferior ao que dispõem as convenções e tratados internacionais. Entretanto, em razão da expansividade e do efeito cumulativo, o Estado poderá instituir mais direitos fundamentais do que os previstos na órbita internacional.

Os direitos fundamentais são prioritários, porque os bens da vida por eles protegidos são essenciais à existência humana. Assim, não obstante a profusão de direitos existentes no ordenamento jurídico, os direitos fundamentais devem ser atendidos com absoluta preferência, porque envolvem discussão acerca da dignidade do ser humano e constituem o pilar do sistema ético de referência de todo o sistema normativo.

A prioridade é determinante na atuação de todas as formas de expressão do poder estatal. Os atos legislativos, administrativos e judiciais devem priorizar o exame e a concretização dos direitos fundamentais, dentro da órbita de sua atuação. Qualquer ato, comissivo ou omissivo, das formas de expressão do poder estatal que não priorize a efetivação dos direitos fundamentais é inconstitucional.

Outra decorrência relevante da característica da prioridade dos direitos fundamentais é que, em caso de lesão, tornam-se urgentes. Direitos fundamentais lesados são os não-efetivados. Esta lesão implica na urgência de seu atendimento pelo Estado.

Impende observar que, em caso de urgência, eventual utilização dos princípios da proporcionalidade e da razoabilidade na efetivação dos direitos fundamentais somente

\footnotetext{
${ }^{73}$ Cf. MENDES, Gilmar Ferreira; COELHO, Inocêncio Mártires; BRANCO, Paulo Gustavo Gonet. Curso de direito constitucional. São Paulo: Saraiva, 2007. p. 229-243. SILVA, José Afonso da. Curso de direito constitucional positivo, cit., p. 180-182. TAVARES, André Ramos. Curso de direito constitucional. 6. ed. São Paulo: Saraiva, 2008. p. 453 e s. ALEXANDRINO, José de Melo. Direitos fundamentais: introdução geral, cit., p. 22 e s.

${ }^{74}$ COMPARATO, Fábio Konder. A afirmação histórica dos direitos humanos, cit., p. 58-59.
} 
será admissível na hipótese de concorrência entre estes direitos e desde que haja insuficiência de recursos materiais. Isto porque todos os direitos fundamentais são prioritários e somente a absoluta ausência de recursos justificaria a delonga na sua consecução material, o que não inviabilizaria, entretanto, a concessão judicial destes direitos na fase de conhecimento. ${ }^{75}$

Os direitos fundamentais constituem um plexo normativo que dispõe sobre as necessidades inerentes à condição humana, sem as quais não se é capaz de existir, desenvolver ou mesmo participar plenamente da vida. ${ }^{76}$ Lembra Adriano Bausola que os direitos fundamentais, além de direitos de realização da liberdade do sujeito, constituem direitos de "adequação da essência do homem", de sua "natureza ideal". 77

Os direitos humanos são, portanto, essenciais ao pleno desenvolvimento da vida em sociedade.

Compondo os direitos fundamentais uma integralidade, ou unidade, que não comporta fracionamento, ${ }^{78}$ a sua classificação em "gerações" ou "dimensões" poderá ser admitida como critério meramente histórico. Não há, essencialmente, qualquer diferença hierárquica ou de prioridade entre as diversas gerações de direitos humanos, de tal sorte que ao Estado cumpre a realização integral e contemporânea destes direitos constitucionais.

Característica de exponencial importância, do ponto de vista de sua tutela, é a aplicabilidade imediata dos direitos fundamentais. Entretanto, dadas as suas peculiaridades, tal característica será analisada quando do exame da eficácia dos direitos fundamentais.

\footnotetext{
${ }^{75}$ Vide infra, Capítulo II, Subseção 7.6, e Capítulo III, Subseções 5.1 e 5.5.

${ }^{76}$ DALLARI, Dalmo de Abreu. Direitos humanos e cidadania. 2. ed. São Paulo: Moderna, 2004. p. 12-13.

${ }^{77}$ BAUSOLA, Adriano. Il fondamento dei diritti umani. In: LIPPOLIS, Laura (Coord.). Diritti umani, poteri degli Stati e tutela dell'ambiente. Milano: Giuffrè, 1993. p. 21-40.

${ }^{78}$ DALLARI, Dalmo de Abreu. A violação dos direitos econômicos, sociais e culturais e seu impacto no exercício dos direitos civis e políticos. In: ENCONTRO BRASILEIRO DE DIREITOS HUMANOS, 1. São Paulo, 1999. São Paulo: Centro de Estudos da Procuradoria Geral do Estado, 2001. p. 69-84. (Série Eventos, 8).

${ }^{79} \mathrm{Cf}$. TAVARES, André Ramos. Curso de direito constitucional, cit., p. 454-455.
} 


\section{A internacionalização dos direitos fundamentais: um sistema aberto e em constante renovação}

Não é possível a plena compreensão dos direitos fundamentais no século XXI sem que o pensamento se projete para a conjuntura histórica que marcou a elaboração da Declaração Universal dos Direitos Humanos.

Em 1945, encerrara-se a Segunda Guerra Mundial, com todas as calamidades e atrocidades decorrentes de um morticínio sem precedentes na história. Em decorrência da guerra, o mundo assistiu a um completo massacre do homem enquanto ser. O arbítrio totalitário produziu as formas mais ultrajantes de redução da condição humana. E os campos de concentração são o exemplo emblemático desta ignomínia.

Os homens, então, puderam compreender que a simples declaração da existência dos direitos humanos, obra encetada no século XVIII, não fora suficiente para evitar que o arbítrio ressurgisse com tamanho vigor. Percebeu-se, naquela quadra da história, que as condições desmoralizantes herdadas da Primeira Guerra Mundial produziram o meio social propício para o surgimento de regimes totalitaristas. A depressão econômica constituiu, como se sabe, a causa principal do triunfo do nazismo. À miséria econômica, seguiu-se a miséria de consciência.

A substância arbitrária germinou e evoluiu em meio às filosofias jurídicas dos séculos XIX e XX, sem que se pudesse, mediante mecanismos jurídicos concatenados, abortar o totalitarismo e suas nefastas consequências. $\mathrm{O}$ positivismo normativista, ${ }^{80}$ nesse passo, conviveu pacificamente com a ascensão arbitrária de Mussolini e de Hitler.

O que sucedera com o Direito? Por que a norma fundamental do Estado, em toda a sua integralidade dogmática, não foi capaz de impedir o aniquilamento em massa de seres humanos? Como pôde o arbítrio suplantar, de forma tão aterradora, a dimensão humana?

A restauração de toda a dimensão ética dos direitos do homem revelou-se uma necessidade. As ideias da Revolução Francesa foram retomadas, mas agora sob uma roupagem universalista. $\mathrm{O}$ valor humano foi estabelecido como essencial e a preservação de seus direitos mostrou-se uma necessidade de sobrevivência. Tornaram-se os direitos

\footnotetext{
${ }^{80}$ Sobre o positivismo jurídico e suas várias correntes doutrinárias, cf. NADER, Paulo. Filosofia do direito. 13. ed. Rio de Janeiro: Forense, 2003. p. 173-194.
} 
humanos os bens mais caros à humanidade, os seus bens soberanos, em relação aos quais as nações firmavam o compromisso ético de efetiva proteção.

Esta renovação ética ultrapassa a barreira do mero formalismo. Trata-se de compromisso baseado na consecução material dos direitos inerentes a todos os seres humanos, indispensáveis para a sua digna sobrevivência e para o seu contínuo aprimoramento.

A partir da Declaração Universal dos Direitos Humanos, de 1948, os Estados voluntariamente aderiram a um compromisso ético, consistente na efetivação dos direitos que, universalmente, foram eleitos como os mais relevantes para a espécie humana. Nasce do consenso entre os Estados, pois, o sistema normativo internacional de proteção dos direitos humanos, emergindo o Direito Internacional dos Direitos Humanos, com significativa repercussão no futuro do Direito Constitucional. ${ }^{81}$

O sistema internacional de proteção dos direitos humanos resulta da adoção de um sistema ético de referência. Este paradigma ético pressupõe a mais completa proteção aos direitos humanos. Assim sendo, os Estados espontaneamente assumiram o compromisso de atuação segundo este mesmo sistema ético de referência.

Flávia Piovesan aponta duas importantes consequências desta novel concepção do Direito Internacional: um processo de relativização da soberania absoluta dos Estados e a concepção do indivíduo como sujeito de direitos na órbita constitucional. ${ }^{82} \mathrm{O}$ homem passa a ser um cidadão do mundo, titular de direitos inerentes à sua condição humana, expressamente reconhecidos por todas as nações. Por outro lado, os Estados concedem parte de sua soberania, a fim de que haja uma harmonização na difusão das regras de proteção dos direitos humanos.

O sistema normativo internacional de proteção dos direitos humanos, portanto, compõe-se de subsistemas estaduais. Macrossistema e subsistemas, entretanto, não se contrapõem, mas se complementam. ${ }^{83} \mathrm{O}$ sistema, como um todo, adota o princípio ético como modelo de trabalho. Todo o sistema, portanto, é permeado pelo sentido axiológico de sua instituição.

\footnotetext{
${ }^{81}$ PIOVESAN, Flávia. Direitos humanos e justiça internacional. São Paulo: Saraiva, 2006. p. 10-11.

${ }^{82}$ PIOVESAN, Flávia. Direitos humanos e justiça internacional, cit., p. 12.

${ }^{83}$ PIOVESAN, Flávia. Direitos humanos e justiça internacional, cit., p. 14.
} 
Desta forma, os direitos fundamentais nada mais são do que os direitos humanos consagrados formalmente em uma Constituição, ${ }^{84}$ por efeito do processo de internacionalização. Não há, entre as expressões, qualquer diferença ontológica, salvo o sentido de institucionalização. De fato, qualquer designação que se faça em relação aos direitos do homem somente poderá ser compreendida a partir do ápice do sistema normativo internacional de proteção dos direitos humanos, o sistema ético de referência.

O sistema internacional se expandiu e se expande continuamente, tendo se institucionalizado na Europa $^{85}$ e nas Américas ${ }^{86}$ de maneira marcante. A internacionalização dos direitos humanos já se reflete, inclusive, na jurisprudência dos países, o que é indicativo de que a proteção destes direitos pelo Poder Judiciário se amplia continuamente. $^{87}$

Na América Latina, aponta-se, como problema comum dos Estados, a ausência de efetivação concreta dos direitos humanos, não obstante a consignação de amplas garantias em suas Constituições. ${ }^{88}$ Este problema é igualmente sentido no Brasil, mui especialmente no que tange aos direitos fundamentais sociais.

O Brasil tem aderido continuamente aos instrumentos internacionais de proteção aos direitos humanos, ${ }^{89}$ assumindo o compromisso de harmonização com o sistema normativo internacional de proteção dos direitos humanos.

No plano jurídico interno, é inequívoca a adesão do Brasil ao sistema internacional de proteção dos direitos humanos. $\mathrm{O}$ art. $5^{\circ}, \S 2^{\circ}$, da Constituição Federal

\footnotetext{
${ }^{84}$ COMPARATO, Fábio Konder. A afirmação histórica dos direitos humanos, cit., p. 224.

${ }^{85}$ Sobre o funcionamento do Tribunal Europeu de Direitos Humanos e a dinâmica de proteção destes direitos, cf. EISSEN, Marc-André. El Tribunal Europeo de Derechos Humanos. Madrid: Civitas, 1985. 175 p. RUIZ MIGUEL, Carlos. La ejecución de lãs sentencias del Tribunal Europeo de Derechos Humanos. Madrid: Tecnos, 1997. 183 p. LAWSON, Rick; BLOIS, Matthijs. The dynamics of the protection of human rights in Europe: essays in honour of Henry G. Schermers. Dordrecht; Boston; London: Martinus Nijhoff Publishers, 1994. v. 3, 416 p. VARELA FEIJÓO, Jacobo. La proteccion de los derechos humanos: jurisprudencia de la Comision Y Tribunal Europeo de Derechos del Hombre. Barcelona: Editorial Hispano Europea, 1972. 372 p. Para uma análise do desenvolvimento dos direitos humanos na Europa, cf. PELLOUX, Robert (Coord.). Essais sur les droits de l'homme em Europe. Torino: G. Giappichelli, 1959. 180 p.

${ }^{86}$ Cf. BUERGENTHAL, Thomas; NORRIS, Robert; SHELTON, Dinah. Protecting human rights in the americas: selected problems. 2. ed. Arlington: Engel, 1986. 389 p.

${ }^{87}$ McCRUDDEN, Christopher. A common law of human rights? transnational judicial conversations on constitutional rights. In: O'DONOVAN, Katherine; RUBIN, Gerry R. (Eds.). Human rights and legal history: essays in honour of Brian Simpson. New York: Oxford, 2004. p. 29-65.

${ }^{88}$ DARRIGRANDE SILVA, Jorge. Los derechos humanos en America. Santiago de Chile: Editorial Jurídica de Chile, 1969. p. 5-10.

${ }^{80}$ PIOVESAN, Flávia. Direitos humanos e o direito constitucional internacional, cit., p. 272-278.
} 
faculta a expansividade dos direitos fundamentais, estabelecendo que o seu rol é meramente exemplificativo. ${ }^{90}$

De outro vértice, os tratados e convenções internacionais sobre direitos humanos, desde que observado o procedimento legislativo constitucional, são erigidos à hierarquia das emendas constitucionais, sobrepondo-se às normas subconstitucionais. Permite o $\S 3^{\circ}$ do art. $5^{\circ}$ da Constituição Federal, portanto, a harmonização do Estado brasileiro com as normas internacionais de proteção aos direitos humanos.

Percebe-se um fluxo renovatório contínuo entre o sistema internacional de proteção dos direitos humanos e a norma fundamental do Estado brasileiro. O macrossistema e o subsistema trabalham em plena consonância, de tal forma a permitirem a constante renovação de um sistema aberto ao movimento progressivo e permanente de proteção aos direitos humanos.

O Estado brasileiro, por conseguinte, relativizou sua soberania, aderindo plenamente ao macrossistema dos direitos fundamentais. ${ }^{91}$ Por consequência, o Brasil adota o sistema ético de referência, o que impele as formas de expressão do poder estatal a concretizarem, contínua e progressivamente, todo o plexo de direitos fundamentais internacionalmente reconhecidos. Qualquer forma de restrição ou supressão de direitos fundamentais, por via comissiva ou omissiva, implica em conduta arbitrária do Estado

\footnotetext{
${ }^{90}$ Cf. MENDES, Gilmar Ferreira; COELHO, Inocêncio Mártires; BRANCO, Paulo Gustavo Gonet. Curso de direito constitucional, cit., p. 259-261.

${ }^{91}$ A prevalência dos tratados sobre o direito interno infraconstitucional está assentada de há muito na doutrina. Cf. REZEK, José Francisco. Direito internacional público: curso elementar. 6. ed. São Paulo: Saraiva, 1996. p. 104-105. O Supremo Tribunal Federal firmou posicionamento no mesmo sentido, não excepcionando os tratados e as convenções relativos aos direitos humanos. Cf. HC 88.420, Rel.Min. Ricardo Lewandowski, julgamento em 17-4-07, DJ de 8-6-07, HC 72.131, voto do Rel. p/ o ac. Min. Moreira Alves, julgamento em 23-11-95, DJ de 1º-8-03, RHC 79.785, Rel. Min. Sepúlveda Pertence, julgamento em 29-3-00, DJ de 22-11-02 e (ADI 1.480-MC, Rel. Min. Celso de Mello, julgamento em 4-997, DJ de 18-5-01. Esta orientação foi contrastada, a nosso ver com razão, por Flávia Piovesan, para quem os direitos humanos decorrentes de tratados internacionais "apresentam valor de norma constitucional". Cf. PIOVESAN, Flávia. Direitos humanos e o direito constitucional internacional, cit., p. 58 e s. O $\S 3^{\circ}$ do art. $5^{\circ}$ da Constituição Federal, com a redação da Emenda Constitucional $n^{\circ} 45$, aparentemente acolhendo o posicionamento do Supremo Tribunal Federal, criou norma intermediária, que permite a elevação dos tratados que disponham sobre direitos humanos à hierarquia das normas constitucionais. Tal regra, contudo, se nos afigura desarmonizada com o sistema normativo internacional de proteção dos direitos humanos, porquanto permitiria a restrição arbitrária de novo direito fundamental declarado na órbita internacional. O Poder Legislativo poderia, portanto, excluir dos brasileiros direito fundamental assegurado a todos os homens, de forma universal. É incompatível, igualmente, com o disposto no art. 60 , $\$ 4^{\circ}$, inciso IV, da Constituição Federal. Cf., ainda, TRINDADE, Antônio Augusto Cançado. O Sistema Interamericano de Direitos Humanos no limiar do novo século: recomendações para o fortalecimento de seu mecanismo de proteção. In: A PROTEÇÃO INTERNACIONAL DOS DIREITOS HUMANOS E O BRASIL. WORKSHOP. Brasília, 7-8 out. 1999. Brasília: Superior Tribunal de Justiça, 2000. p. 31-67.
} 
brasileiro, em absoluta contraposição ao paradigma ético do sistema internacional de proteção.

Esta integração com o sistema internacional de proteção dos direitos humanos alcança, inclusive, o regime político brasileiro.

\section{A exigência democrática de igualdade substancial}

A internacionalização dos direitos fundamentais influenciou os países da América Latina que, a partir de 1980, passaram por intenso processo de democratização e reestruturação de suas instituições, tentando se adaptar às novas questões sociais. ${ }^{92}$

Durante o processo de democratização, iniciado em 1985, o Brasil aderiu a importantes instrumentos internacionais de proteção dos direitos humanos, ${ }^{93}$ fato que se ampliou após a promulgação da Constituição Federal de 1988. Entretanto, como observa José Reinaldo de Lima Lopes, nas décadas de 70 e 80, já se observava a "apropriação política e discursiva pelas classes populares e marginais". ${ }^{94}$

Através da paulatina harmonização com o sistema normativo internacional de proteção dos direitos humanos, o Brasil aderiu à manutenção do regime democrático e à salvaguarda dos direitos fundamentais. ${ }^{95}$ Indigitado compromisso democrático encontra-se consignado, inclusive, nos arts. XXI e XXIX, alínea 2, da Declaração Universal dos Direitos Humanos de $1948 .^{96}$

O fenômeno em tela é por demais significativo e permite a exata compreensão do âmbito de abrangência da proteção a ser dispensada pelos Estados aos fundamentais.

Para Eugène Pelletan, os governos podem ser reduzidos a duas espécies básicas: o despótico, em que as pessoas são possuídas (est possédé), e o democrático, no qual as pessoas se possuem (se possède). ${ }^{97}$ Esta construção bem ilustra o respeito reservado pelo Estado aos cidadãos, conforme a forma de governo adotada.

\footnotetext{
${ }^{92}$ HERSHBERG, Eric; JELIN, Elizabeth (Orgs.). Construindo a democracia: direitos humanos, cidadania e sociedade na América Latina. São Paulo: EDUSP, 2006. p. 19-25.

${ }^{93}$ PIOVESAN, Flávia. Direitos humanos e o direito constitucional internacional, cit., p. 267-272.

${ }^{94}$ LOPES, José Reinaldo de Lima. Direitos sociais: teoria e prática, cit., p. 123.

${ }^{95}$ PIOVESAN, Flávia. Direitos humanos e o direito constitucional internacional, cit., p. 276.

${ }^{96}$ COMPARATO, Fábio Konder. A afirmação histórica dos direitos humanos, cit., p. 231.

${ }^{97}$ PELLETAN, Eugène. Droits de l'homme. 12. ed. Paris: Pagnerre, 1858. p. 19.
} 
O governo despótico, e de resto todas as formas arbitrárias de poder, apresenta como característica fundamental a disposição plena do destino dos cidadãos, facultandolhes os direitos que as vicissitudes políticas permitirem. A democracia, por outro lado, pressupõe o exercício ético na distribuição do poder e, sobretudo, liberdade e igualdade, valores que lhe são básicos. $^{98}$

Por outro lado, Dalmo de Abreu Dallari assenta a supremacia da vontade popular, a preservação da liberdade e a igualdade de direitos como os três elementos caracterizadores do regime democrático. ${ }^{99}$

Uma das dimensões da dignidade do cidadão é a concessão, pelo Estado, do direito de intervenção na vida política, ${ }^{100}$ mediante o reconhecimento da capacidade eleitoral ativa e passiva. Tal dimensão assegura a supremacia da vontade popular.

A liberdade, por outro lado, foi eleita pelo Estado liberal o direito fundamental de maior relevância, destinando-se, essencialmente, a conter os abusos no exercício do poder. Objetivava-se, no liberalismo, reservar ao Estado uma conduta passiva, a sua nãointerferência nos assuntos privados. Todavia, no Estado social, conquanto o direito à liberdade tenha permanecido íntegro, a relevância do direito à igualdade foi substancialmente acentuada, de tal sorte que o seu conceito passou a ter um sentido material, e não mais meramente formal. A garantia de igualdade no Estado social demanda, pois, atuação positiva, com a finalidade de reduzir as desigualdades socioeconômicas, mediante a distribuição equitativa de recursos.

Pressupondo a democracia liberdade e igualdade, compreende-se que a sua completa realização obrigatoriamente exige a proteção dos direitos fundamentais. ${ }^{101}$ Democracia, portanto, é conceito obrigatoriamente anelado à efetiva proteção dos direitos fundamentais. ${ }^{102}$ Se o Estado garante a liberdade dos cidadãos, mas não executa os atos materiais necessários para a consecução efetiva da igualdade substancial, não pode ser considerado realmente democrático.

${ }^{98}$ FERREIRA FILHO, Manoel Gonçalves. Curso de direito constitucional. 34. ed. São Paulo: Saraiva, 2008. p. 101.

${ }^{99}$ DALLARI, Dalmo de Abreu. Elementos de teoria geral do Estado. 26. ed. São Paulo: Saraiva, 2007. p. $150-151$.

${ }^{100}$ ANDRADE, José Carlos Vieira de. Os direitos fundamentais na Constituição Portuguesa de 1976, cit., p. 54-55.

${ }^{101}$ LOPES, José Reinaldo de Lima. Judiciário, democracia, políticas públicas. Revista de Informação Legislativa, Brasília, v. 31, n. 122, p. 256, abr./jun. 1994.

${ }^{102}$ STOTZKY, Irwin P. Creating the conditions for democracy. In: KOH, Harold Hongju; SLYE, C. (Eds.). Deliberative democracy \& human rights. New Haven and London: Yale University Press, 1991. p. 157190. 
A garantia formal da igualdade representa um simulacro de democracia, uma democracia meramente política, mas não social. E, como alerta José Afonso da Silva, embora a democracia política pareça consolidada no Brasil, a democracia social ainda não se realizou, uma vez que demanda realização instrumental por intermédio de políticas públicas. $^{103}$

De fato, a igualdade substancial pressupõe condições materiais adequadas ao desenvolvimento do homem como cidadão, legítimo partícipe das decisões políticas. É indispensável que o homem não esteja sujeito a um grau de degradação material que lhe suprima a plena consciência de sua condição de cidadão. A miséria é incompatível com a lucidez exigida do cidadão, legítimo interveniente dos destinos do Estado, pois submete o ser humano à infame condição de mero sobrevivente, sujeito às injunções biológicas básicas.

A segunda "geração" dos direitos humanos foi concebida exatamente para criar as condições materiais necessárias para o completo aniquilamento da miséria no mundo, esta ultrajante condição, que submete os homens ao arbítrio dos Estados, transformando-os em meros dados estatísticos.

\section{A morfologia dos direitos fundamentais sociais}

O constitucionalismo liberal do século XIX, representado pelas Constituições espanhola (1812), portuguesa (1822), belga (1831) e francesa (1848), desencadeou um maior avanço na efetivação dos direitos fundamentais. A preocupação do legislador constitucional de então era a de conter o poder arbitrário do Estado, ${ }^{104}$ característica fundamental do liberalismo. ${ }^{105}$

\footnotetext{
${ }^{103}$ SILVA, José Afonso da. Governabilidade num Estado democrático. In: VALADÉS, Diego (Coord.). Governabilidad y constitucionalismo em América Latina. México: Unam, 2005. p. 28-29.

${ }^{104}$ Cf. SALDANHA, Nelson. Estado moderno e o constitucionalismo. São Paulo: Bushatsky, 1976. HERRERO DE MIÑ́́N, Mighel. Nacionalismo y constitucionalismo: el derecho constitucional de los nuevos estados. Madrid: Tecnos, 1971. SANCHES VIAMONTE, Carlos. Constitucionalismo: sus problemas, cit.

${ }^{105}$ Cf. GREENE, Theodore Meyer. Liberalismo: teoria e prática. Tradução de Leonidas Gotijo de Carvalho. São Paulo: Ibrasa, 1968. DE RUGGIERO, Guido. Storia del liberalismo Europeo. 5. ed. Bari: Laterza, 1949. STRAUSS, Leo. Liberalismo antico e moderno. Milano: Giuffrè, 1973.
} 
Em plena crise do liberalismo, ${ }^{106}$ o século XX foi marcado pelo surgimento de Constituições inspiradas em ideais sociais. A Constituição mexicana, de 1917, e a Constituição de Weimar, de 1919, passaram a regular, ao lado de direitos e garantias individuais, direitos de alcance nitidamente social. ${ }^{107}$

A transição do Estado liberal para o Estado social, a partir da Revolução Industrial e dos movimentos de afirmação democrática, ${ }^{108}$ altera o paradigma de reconhecimento meramente formal dos direitos fundamentais, vinculando os poderes estatais ao cumprimento de programas de implementação destes direitos. Destaca-se o modelo sueco bem-sucedido, amparado no conceito de gastos com políticas sociais como investimento produtivo, desenvolvido por Gunnar Myrdal, Prêmio Nobel de Ciências Econômicas em 1974. ${ }^{109}$

O Estado tornou-se social, no sentido de que a proteção dos direitos humanos exige interferência ativa para a supressão da miséria e o consequente resgate da dimensão humana. Mas, para tanto, faz-se necessária a garantia de determinadas espécies de direitos não-concebidas pelo Estado liberal, os chamados direitos econômicos, sociais e culturais, ou direitos sociais. ${ }^{110}$

Os direitos sociais protegem determinados bens da vida, cuja garantia, segundo o consenso internacional, diminui os níveis de miséria, promovendo a igualdade substancial entre os homens. Estes bens da vida, ou, do ponto de vista ético, bens soberanos, constituem um núcleo irrevogável e complementar, ${ }^{111}$ a ser atendido através de atos materiais praticados pelo Estado.

\footnotetext{
${ }^{106}$ Cf. HALLOWELL, John. Decline of liberalism as an ideology: with particular reference to german politico-legal thought. London: Kegan Paul, Trench, Trubner, 1946. LUCIUS, Pierre. Agonie du liberalisme. Paris: Sirey, 1938.

${ }^{107}$ A Constituição mexicana de 1917 previa, em seus artigos $3^{\circ}$ e $5^{\circ}$, direito à educação e direitos trabalhistas, respectivamente. A Constituição de Weimar, em seus arts. 119 e 120 a 122, estabelecia proteção à família, além de outros direitos sociais expressos (arts. 157, 159, 160 e 161).

${ }^{108}$ Cf. CASTELLS, Antoni; BOSCH, Núria (Coords.). El futuro del estado del bienestar. Madrid: Civitas, 1998. BONAVIDES, Paulo. Do Estado liberal ao Estado social. 4. ed. Rio de Janeiro: Forense, 1980.

${ }^{109}$ Sobre o desenvolvimento e as características do Welfare State, cf. ARRETCH, Marta. Emergência e desenvolvimento do Welfare State: teorias explicativas. BID, Rio de Janeiro, n. 39, 1995. CARVALHO, Nelson Rojas. Origens do Estado de bem-estar social: uma leitura conservadora. Arché, n. 16, 1997. FARIA, Carlos Aurelio Pimenta de. Uma genealogia das teorias e modelos do Estado de bem-estar social. $B I B$ : revista da Anpocs, n. 46, 1998. DRAIBE, Sônia M. As políticas sociais e o neoliberalismo: reflexões suscitadas pelas experiências latino-americanas. Revista USP, São Paulo, n. 17, p. 86-101, mar/maio 1993.

${ }^{110}$ A doutrina guarda certa reserva quanto à manutenção da categoria jurídica "direitos sociais", e reconhece sua validade apenas para fins classificatórios, históricos e ideológicos, posto que há direitos que não se enquadram precisamente nesta ou em outras categorias. Cf. ABRAMOVICH, Victor; COURTIS, Christina. Los derechos sociales como derechos exigibles. Madrid: Trotta, 2002. p. 47-64.

${ }^{111}$ Cf. COMPARATO, Fábio Konder. A afirmação histórica dos direitos humanos, cit., p. 65-67.
} 
Garantir uma igualdade formal, mediante a edição de normas constitucionais, é tarefa de cunho essencialmente político, que não causa interferência significativa no orçamento do Estado. Entretanto, a consecução da igualdade material exige, para a redução dos níveis de miséria, a estruturação das áreas de atuação dos direitos sociais e o dispêndio expressivo de recursos, em uma cadeia de atos extremamente complexos.

Após declinar o rol de direitos sociais, no seu art. $6^{\circ}$, a Constituição Federal de 1988 dispõe sobre a correlata regulamentação, através de núcleos. Assim, no Título VIII, relativo à ordem social, dispõe a Constituição da República, no Capítulo II, sobre a saúde (Seção II), a previdência social (Seção III) e a assistência social (Seção IV), e, no Capítulo III, sobre a educação (Seção I), a cultura (Seção II) e o desporto (Seção III). Nos respectivos Capítulos IV, V, VI, VII e VIII, trata a Lex Legum da ciência e tecnologia, da comunicação social, do meio ambiente, da família, da criança, do adolescente e do idoso e, finalmente, dos índios. O direito ao trabalho é disciplinado nos art. $7^{\circ}$ ao 11 .

Destes núcleos normativos decorrerão ramificações complexas de normas infraconstitucionais, elaboradas estrategicamente para a satisfação dos bens da vida declinados no art. $6^{\circ}$ da Constituição Federal. Executadas as ramificações, e desde que não incompatíveis com a norma fundamental, o Estado poderá irrigá-las com recursos suficientes, alterando a realidade material dos cidadãos, mediante a consecução, complementar e integral, dos direitos sociais.

Denominamos direitos fundamentais sociais, portanto, aqueles direitos sociais institucionalizados, plasmados em uma Constituição. Estes direitos fundamentais sociais formam uma unidade, uma integralidade, porque a sua soma equivale à totalidade da dignidade da pessoa humana. Entretanto, a Constituição de 1988 reconhece que, para a consecução dos direitos fundamentais sociais, é necessária a sua fragmentação, permitindo a respectiva especialização normativa. Mas, tal fragmentação é meramente funcional, de tal forma que remanesce a unidade dos direitos fundamentais sociais.

A fragmentação, ou divisão, dos direitos fundamentais sociais, permite ao legislador constituinte, originário ou de reforma, criar núcleos constitucionais de irradiação. ${ }^{112}$ Cada núcleo corresponde a um direito fundamental social e à sua ramificação normativa constitucional e infraconstitucional. Os núcleos constitucionais de irradiação dos

\footnotetext{
${ }^{112}$ Não se está a adotar, com a expressão, as teorias absoluta ou relativa do núcleo essencial dos direitos fundamentais, cuja abordagem é diversa da nossa proposição teórica. Sobre a proteção do núcleo essencial dos direitos fundamentais, cf. MENDES, Gilmar Ferreira; COELHO, Inocêncio Mártires; BRANCO, Paulo Gustavo Gonet. Curso de direito constitucional, cit., p. 305 e s.
} 
direitos humanos, como complexos normativos, objetivam satisfazer os bens da vida referidos no art. $6^{\circ}$ da Constituição Federal.

Os núcleos constitucionais de irradiação constituem a matriz normativa de atuação do Estado, sem a qual as formas de expressão do poder estatal não possuem diretiva de conduta. Trata-se de uma matriz que se sobrepõe às normas infraconstitucionais, mas também sujeita a alterações, e direciona a conduta pró-ativa dos órgãos do Estado, no sentido da satisfação dos bens da vida protegidos pelos direitos fundamentais sociais.

A plasticidade dos núcleos de proteção decorre da alta complexidade dos fatos que disciplinam. Assim, por intermédio das emendas constitucionais, os núcleos constitucionais de irradiação poderão ser adaptados, a fim de que sua arquitetura seja aperfeiçoada. A morfologia dos núcleos constitucionais de irradiação, entretanto, não poderá agredir, de forma alguma, quaisquer direitos sociais, sob pena de violação do art. $6^{\circ}$, conjugado com o art. $60, \S 4^{\circ}$, inciso IV, ambos da Constituição Federal.

O nascimento de um direito fundamental dimana do acordo das nações ou da espontânea concepção do Estado. Assim que sua ideia matriz é lançada no sistema, delimitando-se o bem da vida a ser satisfeito, o direito fundamental é institucionalizado pela Constituição Federal de 1988, através dos mecanismos constitucionais de abertura e renovação do sistema.

Depois de gerado, o direito fundamental adquire todas suas características, entre elas a agregação às normas constitucionais invioláveis, "petrificadas", intangíveis pelo poder reformador e pela conduta das demais formas de expressão do poder estatal. Ato contínuo, recebem o poder de irradiação reconhecido pelo Estado, expressado no art. $3^{\circ}$ da Constituição Federal, expandindo-se para todo o ordenamento jurídico.

Os direitos fundamentais sociais, porque dependem de uma atuação concreta do Estado, através de atos materiais específicos para a satisfação dos bens da vida que protegem, provocam irradiação dentro da própria Constituição, a fim de que sejam criados os parâmetros de comportamento dos agentes públicos, em simetria com o princípio da legalidade, princípio capital do regime jurídico-administrativo. ${ }^{113}$

\footnotetext{
${ }^{113}$ Celso Antônio Bandeira de MELLO, após assentar que o princípio da legalidade é específico do Estado de Direito e, portanto, fruto de submissão do Estado à lei, assim se manifesta: "Para avaliar corretamente o princípio da legalidade e captar-lhe o sentido profundo cumpre atentar para o fato de que ele é a tradução jurídica de um propósito político: o de submeter os exercentes do poder em concreto - o administrativo - a
} 
Os parâmetros de comportamento dos agentes públicos, descritos pela Constituição, representam os núcleos constitucionais de irradiação, que permitirão a concreção da ramificação legislativa e a da ação administrativa necessária para a satisfação dos bens da vida salvaguardados pelos direitos fundamentais sociais.

Os efeitos práticos dos núcleos constitucionais de irradiação, entretanto, estão condicionados à atuação material do Estado, o que somente será possível através da intervenção humana.

\section{A satisfação espontânea dos direitos fundamentais sociais pelo Estado: as políticas públicas}

A intervenção humana necessária à materialização dos direitos fundamentais sociais realiza-se através da criação de órgãos pelo Estado ${ }^{114}$. A criação de órgãos permite a necessária especialização das atividades indispensáveis para a precipitação material dos direitos fundamentais sociais. Trata-se de conduta pró-ativa, ou positiva, Estado.

O Estado estabelece na Constituição os seus objetivos e direciona toda a intervenção humana, através dos diversos órgãos e suas atribuições, para a sua realização, em uma alta profusão de atividades. Estas atividades são, essencialmente, a legislativa, a administrativa e a jurisdicional.

A atividade legislativa, ante o princípio da legalidade, cria as normas de conduta dos agentes públicos adequadas à realização dos objetivos do Estado. As normas de conduta vinculação a intervenção humana dos agentes públicos, ${ }^{115}$ representada pela

\footnotetext{
um quadro normativo que embargue favoritismos, perseguições ou desmandos. Pretende através da norma geral, abstrata e por isso mesmo impessoal, a lei, editada, pois, pelo Poder Legislativo - que é o colégio representativo de todas as tendências (inclusive minoritárias) do corpo social -, garantir que a atuação do Executivo nada mais seja senão a concretização desta vontade geral. O princípio da legalidade contrapõese, portanto, e visceralmente, a quaisquer tendências de exacerbação personalista dos governantes. Opõe-se a todas as formas de poder autoritário, desde o absolutista, contra o qual irrompeu, até as manifestações caudilhescas ou messiânicas típicas dos países subdesenvolvidos. O princípio da legalidade é o antídoto natural do poder monocrático ou oligárquico, pois tem como raiz a ideia de soberania popular, de exaltação da cidadania. Nesta última se consagra a radical subversão do anterior esquema de poder assentado na relação soberano-súdito (submisso)" (MELLO, Celso Antônio Bandeira de. Curso de direito administrativo. 18. ed. São Paulo: Malheiros Ed., 2005. p. 90-91).

${ }^{114} \mathrm{O}$ órgão público é definido pela doutrina como "...uma unidade que congrega atribuições exercidas pelos agentes públicos que o integram com o objetivo de expressar a vontade do Estado" (DI PIETRO, Maria Sylvia Zanella. Direito administrativo. 13. ed. São Paulo: Atlas, 2001. p. 417).

${ }^{115}$ Eros Roberto GRAU identifica na atuação estatal atos de intervenção: “Assim, toda atuação estatal é, neste sentido, expressiva de um ato de intervenção. O Estado contemporâneo atua, enquanto tal, intervindo na
} 
atividade administrativa, e a destinação do patrimônio estatal. Caso estas atividades não se harmonizem com os objetivos do Estado, a jurisdição promoverá o realinhamento necessário.

De acordo com os parâmetros traçados pela Constituição Federal, o Estado brasileiro estabeleceu objetivos claros, todos insertos no respectivo art. $3^{\circ}$. Os verbos utilizados são indicativos da conduta pró-ativa do Estado: construir, garantir, erradicar, reduzir e promover. O sentido de realização é evidente, constituindo componente primordial para a compreensão das chamadas políticas públicas.

Política pública, segundo Maria Paula Dallari Bucci, é expressão que abrange todas as formas de atuação do Estado, dentro de uma perspectiva de processos juridicamente articulados. ${ }^{116}$ A afirmação implica no reconhecimento de que todos os atos praticados pelos órgãos do Estado, incluindo-se neste rol os agentes políticos, constituem políticas públicas.

Esta concepção é plenamente consentânea com a ideia de que o poder estatal é uno e se direciona à consecução dos seus objetivos. Assim, políticas públicas, no Brasil, são todas aquelas atividades desenvolvidas pelas formas de expressão do poder estatal tendentes à realização dos objetivos insculpidos no art. $3^{\circ}$ da Constituição Federal. Entre estes objetivos, destaca-se a efetivação dos direitos fundamentais, ${ }^{117}$ com especial enfoque para a igualdade substancial: "construir uma sociedade livre, justa e solidária” (inciso I), "erradicar a pobreza e a marginalização e reduzir as desigualdades sociais e regionais" (inciso III) e "promover o bem de todos, sem preconceitos de origem, raça, sexo, cor, idade e quaisquer outras formas de discriminação" (inciso IV). A garantia de "desenvolvimento nacional” (inciso II) é de objetivo que, em última análise, coadjuva a efetivação da igualdade substancial.

A igualdade substancial somente alcançará sua plenitude através da efetivação dos direitos fundamentais sociais. Ocorre que os objetivos do Estado brasileiro não podem

ordem social. A mera produção do direito (onde a instauração de uma ordem jurídica estatal), a simples definição das esferas do privado e do público - esta última concebida como o universo dentro do qual gravitam os interesses tidos como públicos (e que, por isso, encarnam "questões públicas") -, desde logo consubstanciam expressões de atuação interventiva estatal" (GRAU, Eros Roberto. $O$ direito posto e o direito pressuposto. 7. ed. São Paulo: Malheiros Ed., 2008. p. 25).

${ }^{116}$ BUCCI, Maria Paula Dallari. O conceito de política pública em direito. In: públicas: reflexões sobre o conceito jurídico. São Paulo: Saraiva, 2006. p. 37 e s. (Org.). Políticas

${ }^{117}$ Cf. FREIRE JÚNIOR, Américo Bedê. O controle judicial de políticas públicas. In: BEDAQUE, José Roberto dos Santos; CRUZ E TUCCI, José Rogério (Coords). Temas fundamentais de direito. São Paulo: Ed. Revista dos Tribunais, 2005. v. 1, p. 47-49. 
ser atingidos de forma aleatória. A própria Constituição cria, então, os núcleos constitucionais de irradiação dos direitos fundamentais sociais, que comandam a prática de todos os atos estatais. Pode-se dizer que o destino dos núcleos constitucionais de irradiação é a realização dos direitos fundamentais sociais, e as políticas públicas constituem o seu veículo material.

Por consequência, as políticas públicas estão vinculadas aos núcleos constitucionais de irradiação, de forma que, existindo desvio da matriz constitucional normativa, há necessidade de realinhamento das condutas. Mesmo a alteração indevida do núcleo constitucional de irradiação, por emenda constitucional, poderá gerar o realinhamento de condutas, mediante controle de constitucionalidade. ${ }^{118}$

Nenhuma política pública, portanto, pode violar os direitos fundamentais, porquanto tal representa a transgressão dos próprios objetivos do Estado. Esta diretiva ficou claramente estabelecida no art. $60, \S 4^{\circ}$, incisos II e IV, da Constituição Federal. Ao estabelecer que os direitos fundamentais constituem cláusulas pétreas, ${ }^{119}$ o constituinte originário delimitou claramente o âmbito de liberdade criativa em matéria de políticas públicas.

Impende a observação de que uma política, entendida como programa de ação, somente será pública se atender ao bem comum, ao interesse público. O interesse público está expressamente estabelecido no art. $3^{\circ}$ da Constituição Federal. Uma política será pública, portanto, se atender aos objetivos do Estado brasileiro.

Desta forma, todas as condutas desenvolvidas pelas formas de expressão do poder estatal, por estarem adstritas à realização do interesse público, devem objetivar a efetivação espontânea dos direitos fundamentais. Trata-se do cumprimento espontâneo da obrigação assumida pelo Estado em âmbito nacional e internacional.

Concluímos, portanto, que as políticas públicas constituem os mecanismos estatais de efetivação dos direitos fundamentais, mediante a satisfação espontânea dos bens

\footnotetext{
${ }^{118}$ Sobre a possibilidade do controle de inconstitucionalidade das normas constitucionais, cf. MENDES, Gilmar Ferreira; COELHO, Inocêncio Mártires; BRANCO, Paulo Gustavo Gonet. Curso de direito constitucional, cit., p. 977-981. SILVA, José Afonso da. Curso de direito constitucional positivo, cit., p. 68.

${ }^{119}$ Embora a questão seja tormentosa na doutrina, somos do entendimento de que o alcance do art. $60, \S 4^{\circ}$, inciso IV, da Constituição Federal somente será atingido através de interpretação sistemática, e não meramente restritiva, de forma que os direitos fundamentais sociais necessariamente estão contidos no rol das cláusulas pétreas. Sobre o assunto, cf. SARLET, Ingo Wolfgang. A eficácia dos direitos fundamentais. 9. ed. Porto Alegre: Livr. do Advogado, 2008. p. 424 e s.
} 
da vida por eles protegidos. O Estado, como sujeito passivo da obrigação, as satisfaz através da atuação concreta das formas de expressão do poder estatal.

A percepção em tela é mais fluídica em relação aos atos comissivos das formas de expressão do poder estatal, mas não tão evidente em relação aos atos omissivos, o que repercute diretamente na dimensão da eficácia que se confere, no Brasil, aos direitos fundamentais.

\section{Abordagem sistêmica da eficácia dos direitos fundamentais sociais}

O comando contido no art. $5^{\circ}, \S 1^{\circ}$, da Constituição da República é absolutamente claro: as normas definidoras de direitos fundamentais têm aplicação imediata. A afirmação do constituinte originário revela que a eficácia dos direitos fundamentais no plano interno é plena, ausente qualquer restrição. Trata-se de comando normativo coerente com a própria natureza jurídica dos direitos fundamentais.

Além de irrevogáveis e acumuláveis, os direitos fundamentais constituem uma integralidade, destinada à salvaguarda da dignidade humana. ${ }^{120} \mathrm{~A}$ manutenção da integralidade dos direitos fundamentais é condição indispensável para a garantia da dignidade da pessoa humana. Logo, a admissão de que determinados direitos fundamentais, sobretudo os sociais, não possuem plena eficácia representa a declaração de que o cidadão brasileiro não possui o direito à integralidade da dignidade humana. É o reconhecimento, absolutamente equivocado, de que as formas de expressão do poder estatal dispõem da faculdade de, arbitrariamente, eleger os direitos fundamentais que farão parte do patrimônio jurídico do cidadão.

A questão da eficácia dos direitos fundamentais é resolvida pela abordagem sistêmica. Mediante a utilização de meios racionais para a tradução da unidade e da ordenação do âmbito das normas de proteção dos direitos fundamentais, buscar-se-á atingir a axiologia ou a teleologia do sistema. ${ }^{121}$

O ápice do sistema é a renovação ética materializada na Declaração Universal dos Direitos Humanos de 1948. Com o objetivo explícito de abolir todas as formas

\footnotetext{
${ }^{120}$ Ver supra, Seção 5.

${ }^{121}$ Cf. CANARIS, Claus-Wilhelm. Pensamento sistemático e conceito de sistema na ciência do direito. 3. ed. Lisboa: Fundação Calouste Gulbenkian, 2002. p. 66 e s.
} 
arbitrárias de poder, que historicamente restringiram ou excluíram os direitos humanos, as nações se reuniram para declarar que o valor humano é o mais relevante entre todos. Reconheceram que a dignidade humana somente será preservada caso a integralidade dos direitos humanos seja rigidamente protegida. Assumiram que a realização da igualdade substancial demanda o combate à miséria, constituindo este o papel dos direitos sociais.

O conjunto das nações adotou, portanto, um sistema ético de referência, segundo o qual os direitos fundamentais não podem ser arbitrariamente restringidos ou subtraídos de seus titulares. Estavam eleitos, portanto, os bens soberanos da humanidade, cuja realização representa a estrita observância do sistema ético de referência.

A força do consenso entre as nações criou um sistema normativo internacional de proteção dos direitos humanos, capaz de responsabilizar as nações aderentes em caso de inobservância do sistema ético de referência. As nações pactuantes se comprometeram a harmonizar os subsistemas ao macrossistema de proteção dos direitos humanos, admitindo a relativização de sua soberania.

O art. $4^{\circ}$, inciso II, da Constituição da República Federativa do Brasil acolheu o princípio da prevalência dos direitos humanos nas relações internacionais, alinhando-se expressamente com o macrossistema. Permitiu o Estado brasileiro a abertura do subsistema ao macrossistema nos $\S \S 2^{\circ}$ a $4^{\circ}$ do art. $5^{\circ}$ da Lex Legum, admitindo, mesmo que indiretamente, a relativização de sua soberania.

Em perfeita harmonia com a Declaração Universal dos Direitos Humanos, a Constituição Federal adotou, em seu art. $1^{\circ}$, caput, a democracia como forma de governo, consagrando a soberania popular como fundamento da República Federativa do Brasil (inciso I). A República Federativa do Brasil, como corolário desta opção, assinalou que igualmente constituem seus fundamentos a cidadania (CF, art. $1^{\circ}$, inciso II) e a dignidade da pessoa humana (inciso III).

Acolheu, o Estado brasileiro, portanto, o postulado da igualdade substancial, entrelaçado com a estrita proteção dos direitos fundamentais. A proteção irrestrita dos direitos fundamentais constitui, nos termos do art. $3^{\circ}$ da Constituição da República, objetivo do Estado brasileiro.

Para atingir os seus objetivos, o Estado brasileiro declinou rol não-exaustivo dos direitos fundamentais nos arts. $5^{\circ}$ (direitos e garantias individuais), $6^{\circ}$ a 11 (direitos sociais), 12 a 13 (direitos de nacionalidade) e 14 a 17 (direitos políticos) da Constituição 
Federal. Os direitos fundamentais sociais foram explicitados no art. $6^{\circ}$, conjugando-o harmonicamente com os núcleos constitucionais de irradiação contidos no Título VIII da Constituição Federal, destinados a permitir a ramificação infraconstitucional através de políticas públicas.

Todo o aparato orgânico descrito revela que o objetivo do sistema é a plena realização dos direitos fundamentais. Os direitos humanos, portanto, já produziam efeitos antes mesmo de se positivarem. A irradiação dos direitos humanos, com toda a sua carga ética, ao contrário do que se possa supor, independe da aceitação do Estado, uma vez que a sua gênese é o consenso das nações.

Do ponto de vista do macrossistema, ao qual o Estado brasileiro está voluntariamente integrado, os direitos fundamentais detêm eficácia plena, independentemente de qualquer consignação em texto constitucional. Por esta razão, a diretiva contida no art. $5^{\circ}, \S 1^{\circ}$, da Constituição Federal representa a mera reiteração de que o Estado brasileiro reconhece a plena e imediata eficácia dos direitos humanos, em toda a sua extensão jurídica.

A intangibilidade dos direitos fundamentais, prevista no art. $60, \S 4^{\circ}$, incisos II e IV, da Constituição Federal explicita a harmonização do Brasil ao sistema ético de referência. Nenhum ato legislativo, mesmo que por emenda à constituição, poderá atingir a eficácia dos direitos fundamentais. Não há possibilidade de restrição ou mesmo exclusão arbitrárias dos direitos fundamentais por qualquer via legislativa, administrativa ou jurisdicional.

Caso o próprio constituinte originário decidisse reduzir o alcance dos direitos fundamentais arbitrariamente, estaria contrariando o sistema ético de referência e, por via de consectário lógico, o sistema normativo internacional de proteção aos direitos humanos. Nesta hipótese, o Brasil desligar-se-ia do sistema internacional, alinhando-se entre os países que adotam postura arbitrária no uso do poder, ou seja, que se fundamentam no sistema arbitrário de referência, historicamente estigmatizado pela ordem internacional.

Há uma distinção sutil que deve ser realizada, sob pena de se causar séria crise na efetivação dos direitos fundamentais.

O direito fundamental assegurado não se confunde com os mecanismos que o Estado elegerá para a sua satisfação espontânea. Os direitos fundamentais nada mais são do que os direitos erigidos ao nível internacional para a proteção da dignidade humana, 
positivados em uma Constituição. Tais direitos subjetivos geram para o seu titular o poder de pleitear a sua satisfação contra o Estado, ou até mesmo em face do particular. Trata-se de direitos já assegurados na órbita interna e internacional, de forma que, em caso de lesão, ou ameaça de lesão, podem ser imediatamente exigidos, nos termos do que dispõe o art. $5^{\circ}$, inciso XXXV, da Constituição Federal.

Como os direitos fundamentais constituem uma integralidade, é logicamente incompatível a conclusão de que os direitos fundamentais sociais não possuem plena eficácia, ou aplicabilidade imediata. Um dos argumentos utilizados é a referência, pela Constituição, da necessidade da construção de uma norma integradora, ${ }^{122}$ o que limitaria a eficácia de determinados direitos fundamentais, em especial os sociais.

O equívoco desta abordagem consiste na inobservância de que os direitos subjetivos constitucionais foram expressamente previstos no art. $6^{\circ}$ da Constituição Federal, de forma que sua eficácia é imediata. Entretanto, as chamadas normas integradoras são derivadas de políticas públicas para o atendimento espontâneo destes direitos. Tais políticas públicas serão conduzidas segundo o apropriado núcleo constitucional de irradiação, que em si mesmo pode ser alterado para melhor atendimento deste desiderato.

Assim é que qualquer cidadão brasileiro, lesado em seu direito à saúde, previsto no art. $6^{\circ}$ da Constituição Federal, poderá exigi-lo judicialmente, de forma coletivizada. ${ }^{123}$ Entretanto, antes que isso ocorra, o próprio Estado poderá antecipar-se à satisfação do bem da vida, porque já estabeleceu parâmetros constitucionais de comportamento das políticas públicas, os núcleos constitucionais de irradiação. No que se refere ao direito à saúde, o Estado poderá, mediante políticas públicas vinculadas ao núcleo constitucional de irradiação contido nos arts. 196 a 200 da Constituição Federal, realizá-lo espontaneamente. As diretrizes para a realização do direito assegurado estão contidas no núcleo constitucional de irradiação, cuja finalidade é a satisfação espontânea do bem da vida saúde.

Aquilo que se convencionou chamar de normas programáticas ${ }^{124}$ refere-se, a nosso ver, às normas vinculadas aos objetivos a serem alcançados pelo Estado, através de programas articulados e executados por intermédio das políticas públicas. A norma

\footnotetext{
${ }^{122}$ Cf. SILVA, José Afonso da. Curso de direito constitucional positivo, cit., p. 180.

${ }^{123}$ Vide infra, Capítulo III, Seção 4.

${ }^{124}$ Cf., por todos, SILVA, José Afonso da. Aplicabilidade das normas constitucionais. 3. ed. São Paulo: Malheiros Ed., 1998. p. 135.
} 
integradora, portanto, não se destina a garantir a eficácia do direito fundamental social, mas a capacitar o Estado à sua satisfação espontânea.

Este é o sentido que emprestamos à expressão programática.

Do ponto de vista da interpretação sistêmica proposta, direitos fundamentais sociais são os direitos subjetivos previstos no art. $6^{\circ}$ da Constituição Federal, de eficácia plena e aplicabilidade imediata. São direitos imediatamente exigíveis do Estado pela via jurisdicional.

Os núcleos constitucionais de irradiação, notadamente concentrados no Título VIII da Lex Legum, é que detêm a força principiológica das normas programáticas e dependem de normas integradoras. Representam a iniciativa estatal de satisfação espontânea dos direitos fundamentais sociais, mas não vinculam a sua eficácia.

Há que se distinguir, portanto, a eficácia plena e imediata dos direitos fundamentais sociais e a eficácia limitada dos núcleos constitucionais de irradiação. Esta distinção é absolutamente consentânea com o sistema ético de referência, porquanto não limita a eficácia dos direitos fundamentais ao arbítrio do Estado. Ao contrário, atende à demanda de consecução dos bens soberanos da humanidade e permite ao Estado, nas hipóteses de injunções políticas internas de conteúdo arbitrário, ${ }^{125}$ conferir aos cidadãos os direitos fundamentais sociais através da jurisdição.

Esta confusão entre o direito e os mecanismos jurídicos para a sua satisfação espontânea pelo Estado tem causado uma crise de aplicabilidade das normas de proteção aos direitos fundamentais sociais. O Poder Judiciário, em meio a esta crise, busca equacionar o âmbito de sua atuação na efetivação dos direitos fundamentais, em especial os sociais.

\footnotetext{
${ }^{125} \mathrm{~A}$ negativa de direitos fundamentais aos cidadãos, sem o sustentáculo do consenso universal, constitui ato de arbitrariedade. Desta forma, todas as formas de expressão do poder estatal podem atuar arbitrariamente se, ausente consenso universal, restringirem ou excluírem direitos fundamentais sociais.
} 


\section{CAPÍTULO II. CRISE ENTRE AS FORMAS DE EXPRESSÃO DO PODER ESTATAL: O PAPEL DO JUDICIÁRIO NA EFETIVAÇÃO DOS DIREITOS FUNDAMENTAIS SOCIAIS}

\section{A teoria da separação dos poderes em Montesquieu}

A concepção do Estado moderno, obra encetada a partir do século XVII pelos pensadores europeus, constituiu imenso desafio à organização da sociedade de então. Buscou-se, em um primeiro momento, substituir a vontade individual dos governantes pela vontade geral e abstrata da lei, concebendo-se o Poder Legislativo e o Poder Executivo como entidades promoventes do bem comum.

Contrariando a visão naturalista da sociedade, propugnada a partir da definição aristotélica do homem, como animal naturalmente político, ${ }^{126}$ iniciou-se, na opção filosófica que se convencionou denominar contratualismo, uma fase de transição do estado da natureza para o estado civil.

Encontramos a primeira referência expressa a esta transição na obra Leviatã, datada de 1651. Nela, Thomas Hobbes afirma que, consideradas as tendências inferiores dos homens no estado da natureza, impelidos que se encontram ao contínuo estado de guerra, impositivo que, através de sua racionalidade, estabeleçam o estado social, mediante a aceitação voluntária. Celebram, pois, os homens, um contrato com mútua transferência de direitos. $^{127}$

As ideias de Hobbes, acerca do Estado como um todo orgânico, acabaram por influenciar o absolutismo inglês do século XVII.

\footnotetext{
${ }^{126}$ ARISTÓTELES. Política. 5. ed. São Paulo: Martin Claret, 2008. Livro I, capítulo II, p. 56-57. (Coleção a Obra-Prima de Cada Autor).

${ }^{127}$ HOBBES, Thimas. Leviatã. São Paulo: Rideel, 2005. Parte I, Capítulos XIII e XIV, p. 74-85. (Biblioteca Clássica).
} 
O absolutismo hobbesiano foi flagrantemente atacado por John Locke, ${ }^{128}$ que exerceu grande influência na Revolução Inglesa de 1688 e na Revolução Americana de 1776, alinhando-se ao naturalismo aristotélico.

Substituindo a ideia hobbesiana de supremacia e dominação pelo desejo de paz, Montesquieu afirma que nenhuma sociedade sem governo pode subsistir, ${ }^{129}$ discorrendo sobre a importância das leis para a garantia da vida em sociedade. ${ }^{130}$

Em 1762, com a publicação de O Contrato Social, Rousseau retoma o contratualismo propugnado por Hobbes, qualificando a ordem social como um direto sagrado, fundamento de todos os demais. Para Rousseau, é a vontade, e não a natureza, o fundamento da sociedade. Com a consciência de que a liberdade e a força conjunta são instrumentos indispensáveis para a sobrevivência, os homens abdicam de seus direitos em favor da coletividade. Assim, o corpo social manifesta a sua vontade através da vontade geral de todos os seus componentes, de forma que o fim de toda legislação é o de garantir o bem geral de todos, constituindo seus objetos principais a liberdade e a igualdade. ${ }^{131}$

A lei, entretanto, assumirá uma concepção soberana e imutável em Montesquieu, distinguindo-se, em sua concepção lata, dos demais atos humanos fundados na vontade individual. ${ }^{132}$

Assim é que Montesquieu condiciona a liberdade dos cidadãos à divisão das funções do Estado, criando a teoria da separação dos poderes. Segundo o prestigiado teórico político, a reunião de tais poderes permite o surgimento de leis tirânicas, exequíveis igualmente de forma tirânica. ${ }^{133}$ Para Montesquieu, a maior liberdade possível a ser concedida aos cidadãos pelo Estado decorre da existência, não de um, mas de vários

\footnotetext{
${ }^{128}$ LOCKE, John. Segundo Tratado sobre o Governo. São Paulo: Martin Claret, 2006. Capítulo XVIII, p. 137-143. (Coleção Obra-Prima de Cada Autor).

${ }^{129}$ Cf. FAGUET, Emile. La politique comparée de Montesquieu, Rousseau et Voltaire. Paris: Société Français d'Imprimerie et de Librairie, 1902.

${ }^{130}$ MONTESQUIEU, Charles de Secondat, Baron de. O espírito das leis. Trad. Pedro Vieira Mota. 9. ed. São Paulo: Saraiva, 2008. Livro I, cap. III. O Espírito das Leis: Montesquieu: as formas de governo. A federação. A divisão dos poderes, p. 83-86.

${ }^{131}$ ROUSSEAU, Jean Jacques. O contrato social. São Paulo: Martin Claret, 2008. p. 44-49, Livro II, Capítulos VI e VII. (Coleção Obra-Prima de Cada Autor).

${ }^{132}$ COMPARATO, Fabio Konder. Ensaio sobre juízo de constitucionalidade de políticas públicas. Revista dos Tribunais, São Paulo, ano 86, n. 737, p. 11-22, mar. 1997.

${ }^{133}$ MONTESQUIEU. O Espírito das Leis, cit., Livro XI, Capítulo VI.
} 
poderes que, opondo-se entre si, moderar-se-iam reciprocamente, impedindo o abuso por parte de um deles. ${ }^{134}$

Impende observar, com Dalmo de Abreu Dallari, que a teoria foi consagrada em momento histórico no qual se pretendia o enfraquecimento do Estado e a sua restrição na esfera de liberdade individual. ${ }^{135}$

A teoria da separação de poderes foi concebida, portanto, para assegurar a existência de um governo moderado, mediante distribuição das atividades do Estado e consequente controle recíproco entre suas formas de expressão. ${ }^{136}$

Trata-se da tentativa de "contenção do poder pelo poder", na feliz expressão de Ernesto Pedraz Penalva. ${ }^{137}$

A teoria da separação objetivava o controle do poder em benefício da coletividade, não se tratando de mera racionalização da atividade estatal. Montesquieu pretendia, portanto, evitar a concentração de poderes, de tal forma que os direitos e liberdades fundamentais fossem protegidos das investidas do poder arbitrário. ${ }^{138}$

A teoria da separação dos poderes destina-se, em última análise, a conferir proteção aos direitos fundamentais de primeira geração contra as iniciativas arbitrárias do Estado. A ideia em questão partiu do modelo da monarquia constitucional inglesa, a fim de que se pudesse erigir como princípio de ordem constitucional aplicável aos governos de índole moderada.

Neste aspecto, o princípio da separação dos poderes serviu para refrear a contínua interferência da realeza nas decisões dos juízes. Os reis ingleses, por sua influência direta na composição e na atuação dos órgãos jurisdicionais, não raras vezes tentavam intervir nas decisões exaradas nos casos concretos de maior relevância, a fím de que certas orientações do Parlamento não fossem adotadas. ${ }^{139}$

Esta indevida interferência não poderia ser tolerada em um momento histórico no qual os direitos e as liberdades individuais estavam em plena afirmação. Se a lei é o comando geral e abstrato derivado da vontade soberana do povo, então qualquer

\footnotetext{
${ }^{134}$ RIPAMONTI, Cristian Bulnes. Relaciones y conflictos entre los organos del Poder Estatal. Chile: Editorial Jurídica de Chile, 1967. p. 5-24.

${ }^{135}$ DALLARI, Dalmo de Abreu. Elementos de teoria geral do Estado, cit., p. 216.

${ }^{136}$ RIPAMONTI, Cristian Bulnes. Relaciones y conflictos entre los organos del Poder Estatal, cit., p. 5-24.

${ }^{137}$ PEDRAZ PENALVA, Ernesto. Constitucion, jurisdiccion y proceso. Madrid: Akal, 1990. p. 9-42.

${ }^{138}$ ROCHA, José de Albuquerque. Estudos sobre o Poder Judiciário, cit., p. 60-62.

${ }^{139}$ LOVELAND, Ian. Constitutional law, administrative law, and human rights: a critical introduction. 4. ed. Oxford: Oxford University Press, 2006. p. 56-69.
} 
interferência em sua aplicação aos casos concretos representava grave comprometimento à ordem geral.

Viria a surgir na Inglaterra, ${ }^{140}$ posteriormente, o princípio da rule of law como fundamento para que o Poder Judiciário regulasse, de forma gradual, o comportamento do governo, mediante a aplicação da racionalidade constitucional. ${ }^{141}$

Na França, a teoria da separação objetivava também a restrição dos poderes dos magistrados. ${ }^{142}$ Como agentes delegados dos soberanos, os juízes franceses gozavam, à época da Revolução Francesa, de grande poder, e não raro permitiam que a arbitrariedade dos soberanos se projetasse em suas decisões. As injustiças nas decisões e o arbítrio incontido dos órgãos judiciários constituíram os motivos determinantes para a punição de juízes e a adaptação do Poder Judiciário durante a Revolução Francesa, bem como para a concepção do Poder Judiciário como um apêndice do Poder Legislativo. ${ }^{143}$

Lembra-nos Dalmo de Abreu Dallari que Montesquieu exerceu a magistratura. Entretanto, o seu acesso às funções judicantes operou-se hereditariamente. Assim é que Montesquieu herdou de um tio, no ano de 1716, o cargo de membro do Parlement de Bordeaux, órgão judiciário coletivo, cargo que acabou vendendo por necessidade financeira e porque não nutria qualquer interesse pela atividade. ${ }^{144}$

A experiência de Montesquieu nas funções judicantes, mas segundo um sistema arbitrário de referência, a partir do qual o poder era exercido como função delegada do rei e sob o prisma de vantagem econômica para seu detentor, certamente o

\footnotetext{
${ }^{140} \mathrm{Na}$ Inglaterra inexiste qualquer mecanismo institucional, externo ao Parlamento, de controle da constitucionalidade das leis. Isto porque praticamente não há diferença de status entre as leis constitucionais e as leis ordinárias produzidas pelo Legislativo. Como afirma Aléxis de Tocqueville, "Ali, pois, a Constituição pode mudar incessantemente, ou melhor, não existe. O Parlamento, ao mesmo tempo que é um corpo Legislativo, é um corpo constituinte" (TOCQUEVILLE, Aléxis de. A democracia na América. 2. ed. Belo Horizonte: Itatiaia. São Paulo: EDUSP, 1977. p. 83). Oportuna, ainda, a observação de David Robertson, nesta linha de considerações, de que a "Lord Law não possui atores políticos de grande importância" (ROBERTSON, David. Judicial discretion in the house of lords. Oxford: Clarendon Press, 1998. p. 3-43).

${ }^{141}$ LOVELAND, Ian. Constitutional law, administrative law, and human rights: a critical introduction, cit., p. 70-71.

${ }^{142} \mathrm{Na}$ França, atualmente, advoga-se o reforço da separação dos poderes como garantia de uma sociedade igualitária, ao mesmo tempo em que se postula a separação da justiça do Estado, tal como a decisão fundamental para a República com a separação entre o Estado e a Igreja. Cf. VARAUT, Jean-Marc. Le droit au juge. Paris: Quai Voltaire, 1991. p. 259-260.

${ }^{143}$ RENOUX, Thierry. Le Conseil Constitutionnel et l'autorite judiciaire: l'élaboration d'ún droit constitutionnel juridictionnel. Paris: Economica, 1984. p. 19-21.

${ }^{144}$ DALLARI, Dalmo de Abreu. O poder dos juízes. São Paulo: Saraiva, 1996. p. 15.
} 
influenciou na elaboração da tese segundo a qual a função de magistrado deveria ser temporária, a fim de que se evitasse o arbítrio no seu exercício. ${ }^{145}$

A tese de Montesquieu influenciou diretamente a Constituição francesa de 1791, que estabeleceu a eletividade e a temporariedade como características da função jurisdicional, o que foi alterado somente no sistema republicano de $1848 .{ }^{146}$

Na época em que foi concebida, a teoria da separação dos poderes pretendia promover a proteção dos direitos fundamentais de primeira geração, mediante o controle do poder. A restrição do poder dos órgãos do Estado era indispensável, em uma fase histórica na qual o despotismo pregava o poder absoluto e arbitrário. Foi, portanto, a primeira reação ao arbítrio, consignada nos textos constitucionais, com o específico fim de adequar o perfil das forças de expressão do poder estatal.

As concepções de Montesquieu acabaram por influenciar as Constituições liberais, ${ }^{147}$ repercutindo profundos efeitos, até o presente, nas Constituições promulgadas nos Estados que advogam a implementação do bem-estar social, em função da utilização de um paradigma exclusivamente liberal.

\section{Reflexos da transição do Estado liberal para o Estado social na teoria da separação dos poderes}

O modelo do constitucionalismo liberal preocupa-se, com exclusividade, em proteger o indivíduo da ingerência do Estado, não lhe carreando qualquer orientação finalística em termos de ação governamental. Este estado de coisas altera-se com o fenômeno histórico da Revolução Industrial, cuja expansão tecnológica permitiu a produção e o consumo em massa, bem como a integração global da informação. ${ }^{148}$

A transição entre o Estado liberal e o Estado social promove alteração substancial quanto à concepção de Estado e de sua finalidade.

\footnotetext{
${ }^{145}$ DALLARI, Dalmo de Abreu. O poder dos juízes, cit.

${ }^{146}$ DALLARI, Dalmo de Abreu. O poder dos juízes, cit., p. 16.

${ }^{147}$ Cf. LA PENSÉE politique et constitutionelle de Montesquieu: bicentenaire de l'Esprit des lois, 1748-1948. Université de Paris. Institut de Droit Compare. Paris: Recueil Sirey, 1952.

${ }^{148}$ COMPARATO, Fabio Konder. Ensaio sobre juízo de constitucionalidade de políticas públicas, cit., p. 1516.
} 
O dirigismo estatal, característica do Estado social, implica no estabelecimento de funções específicas aos Poderes Públicos para a consecução de metas predeterminadas pela coletividade. $^{149}$

Até um determinado ponto da história, a proteção dos direitos fundamentais de primeira geração foi o principal alvo de preocupação da teoria política. Entretanto, as consequências econômicas do uso das máquinas, durante a Revolução Industrial, provocou uma enorme expansão da riqueza e o surgimento do imperialismo econômico. O século XX foi o palco da expansão industrial e da produção em massa.

A concentração de riqueza acabou gerando gigantescos bolsões de miséria nas classes inferiores, permitindo, como já visto, ${ }^{150}$ a expansão das ideias totalitárias, amparadas em um sistema arbitrário de referência, com as consequências nefastas das duas últimas grandes guerras mundiais.

A reação a este estado de coisas foi a opção da adoção, em âmbito mundial, de um novo sistema ético de referência, ${ }^{151}$ baseado na proteção intransigente dos direitos humanos. Neste cariz, o reconhecimento de que a miséria era uma das causas determinantes para o surgimento de ideais totalitários ensejou a afirmação do direito de igualdade como princípio de ordem substancial. Assim, o compromisso dos Estados pactuantes não se restringiu à garantia formal dos direitos humanos de primeira geração, mas evoluiu para a proteção de uma nova geração de direitos, voltada à consecução da igualdade material.

A partir de 1948, com a assinatura da Declaração Universal dos Direitos Humanos, os Estados se comprometeram a assegurar novos bens da vida, indispensáveis para a sobrevivência da humanidade. ${ }^{152}$ Nesta transição do Estado liberal para o Estado social, os direitos de primeira geração seriam efetivamente protegidos caso assegurados, mediante ações afirmativas, outros bens da vida, tais como a saúde, a educação, o trabalho, a habitação, a família, entre outros. ${ }^{153}$

\footnotetext{
${ }^{149}$ BONAVIDES, Paulo. Do Estado liberal ao Estado social, cit.

${ }^{150}$ Ver supra, Capítulo I, Seção 1.

${ }^{151}$ Ver supra, Capítulo I, Seção 2.

${ }^{152}$ CAPOGRASSI, Giuseppe. Dichiarazione Universale dei Diritti dell'Uomo: Convenzione per la Proscrizione del Genocidio. Padova: CEDAM, 1950. p. 13.

${ }^{153}$ CAPPELLETTI, Mauro; GARTH, Bryant. Acess to justice: a world survey. Milano: Giuffrè, 1978. v. 1, p. 6-9.
} 
Protegidos juridicamente os bens soberanos, ${ }^{154}$ através de um documento escrito e com adesão de inúmeros países, far-se-ia necessária a elaboração de programas de atuação para que estes bens pudessem ser efetivamente conferidos aos cidadãos. Entretanto, para a realização deste compromisso ético, cada Estado seria o responsável pela criação dos programas e sua execução.

Sem dúvida alguma, a estabilidade objetivada no Estado liberal é substituída pelo dirigismo estatal, alterando-se, de forma profunda, a concepção da teoria da separação dos poderes. ${ }^{155}$ Como observa Pedro Timotheo, aquele modelo rígido de separação de poderes, baseado na independência, ausência de rivalidades, sem entrechoques, sem conflitos, restou "abolido das modernas constituições de quase todos os países". ${ }^{156}$

Os programas de atuação estatal, contudo, tendem à satisfação espontânea dos direitos fundamentais, mas não condicionam a sua exigibilidade em face do Estado, porque já assegurados na órbita interna e internacional. ${ }^{157}$

Notamos, portanto, uma nova conformação do Estado e, por via de consectário lógico, da teoria da separação de poderes. Esta teoria não pode, evidentemente, ser um fim em si mesma, e deve estar estritamente ligada às finalidades do Estado. ${ }^{158}$ Por conseguinte, com a alteração das finalidades estatais, altera-se igualmente a concepção da teoria da separação dos poderes.

No Estado liberal, o objetivo da teoria, consoante já assentado, era o de evitar a concentração de poderes, a fim de que os direitos fundamentais de primeira geração fossem assegurados. O Estado, na premissa liberal, é um elemento catalisador do poder, instrumento para a sua contenção, em estrito respeito à liberdade individual. No Estado social, este objetivo permanece, mas se lhe é acrescentado o desiderato de realização dos direitos fundamentais de segunda e outras gerações, com o propósito de se assegurar a igualdade substancial entre os cidadãos. De uma conduta meramente negativa, passiva, o Estado assume, também, uma conduta pró-ativa.

\footnotetext{
${ }^{154}$ Ver supra, Capítulo I, Seção 2.

${ }^{155}$ COMPARATO, Fabio Konder. Ensaio sobre juízo de constitucionalidade de políticas públicas, cit., p. 1617.

${ }^{156}$ TIMOTHEO, Pedro. O Poder Judiciário sob a nova Constituição da República. [s.l.]: [s.e.], 1939. p. 2527.

${ }^{157}$ Vide supra, Capítulo I, Seção 9.

${ }^{158}$ FREIRE JÚNIOR, Américo Bedê. O controle judicial de políticas públicas, cit., p. 38.
} 
Constituindo uma "ordem jurídica soberana que tem por fim o bem comum de um povo situado em determinado território", ${ }^{159}$ o Estado necessita de órgãos que atuem para a realização desta finalidade, segundo os parâmetros traçados pela Constituição. Entretanto, cada órgão está vinculado às finalidades do Estado, de forma que devem atuar de maneira coordenada para a respectiva consecução.

Este equilíbrio é que deverá pautar as relações entre as formas de expressão do poder estatal. Todavia, um novo componente será adicionado à equação, com a assunção, pelo Poder Judiciário, de uma relevante atribuição constitucional.

\section{O exercício do controle de constitucionalidade pelo Poder Judiciário: o início da discussão sobre a "judicialização da política"}

No início do século XIX, durante a expansão da Revolução Industrial, ${ }^{160}$ iniciou-se um movimento de absorção das questões políticas pelo Poder Judiciário. Algumas questões que, no curso da história, sempre foram consideradas de caráter exclusivamente político, passaram a ser examinadas sob a ótica do Direito. ${ }^{161}$ É o que se convencionou designar como political questions, nos Estados Unidos, acts of State, na GrãBretanha, actes de gouvernment, na França, e justizfreien Hoheitsakte, na Alemanha.

David M. O’Brien aponta a origem das political questions nas observações lançadas pelo Chief Justice John Marshall, no caso Marbury v. Madison, 5 U.S. 137, de 1803. ${ }^{162}$ Naquela ocasião, Marshall afirma que pertence ao Poder Judiciário a prerrogativa de decidir se a questão é, ou não, política, admitindo a apreciação, pela Suprema Corte, da

\footnotetext{
${ }^{159}$ DALLARI, Dalmo de Abreu. Elementos de teoria geral do Estado, cit., p. 119.

${ }^{160} \mathrm{Na}$ Inglaterra, onde o processo de industrialização foi mais avançado, o desenvolvimento de uma consciência britânica da classe trabalhadora pôde coordenar esforços para a petição de direitos sociais (social rights). Em toda a Europa a industrialização promoveu a formação de uma classe de trabalhadores com consciência de seus direitos. Cf. ISHAY, Micheline R. The history of human rigths: from ancient times to the globalization era, cit., p. 117-139.

${ }^{161}$ Sobre os precedentes da constitucionalização da função judicial, cf. BERGALLI, Roberto. Estado democrático y cuestión judicial: vias para alcanzar una auténtica y democrática independencia judicial. Buenos Aires: Depalma, 1984. p. 25-41.

${ }^{162}$ O'BRIEN, David M. Constitutional law and politics: civil rights and civil liberties. 6. ed. New York: Norton, 2005. v. 2, p. 119.
} 
constitucionalidade das leis. Firma-se, assim, a Suprema Corte dos EUA como o árbitro final das questões constitucionais. ${ }^{163}$

Esta decisão, segundo Mauro Cappelletti, é a origem do mais antigo sistema de controle de constitucionalidade. ${ }^{164}$

Evidentemente, a análise de constitucionalidade, em sua origem, restringiu-se aos atos legislativos, evoluindo paulatinamente. Neste sentido, a Suprema Corte dos Estados Unidos ${ }^{165}$ examinou, em 1849, o caso Luther v. Borden, 7 How [48 U.S.] 1, decidindo que a questão de se saber se Rhode Island tem uma forma republicana de governo, como garantido pelo "Article IV of the Constitution", deveria ser resolvida pelo Congresso, e não pelo Judiciário. ${ }^{166}$

Como se observa, os precedentes mencionados centram-se no pressuposto de que a natureza exclusivamente política do ato deve ser estabelecida pelo tribunal. Esta novel função, reconhecida pelo próprio Poder Judiciário, representa uma enorme evolução em relação à teoria da separação dos poderes formulada por Montesquieu. O Poder Judiciário, segundo sua filosofia, era um mero aplicador da lei ao caso concreto, tal como posta pelo Poder Legislativo, não lhe cabendo, de modo algum, realizar qualquer avaliação de sua adequação no ordenamento jurídico.

O controle de constitucionalidade altera o papel do Poder Judiciário, inicialmente concebido por Montesquieu, reservando-lhe a palavra final nos atos praticados pelas outras formas de expressão do poder estatal. Este é, sem dúvida, o prelúdio da admissão do controle judicial de quaisquer atos de governo que, materializados, vulnerarem a Constituição.

O novo papel do Poder Judiciário evidentemente causaria reação de todos quantos fossem atingidos pelos efeitos do controle de constitucionalidade. Os universos

\footnotetext{
${ }^{163}$ COUNTRYMAN, Edwin. The Supreme Court of the United States: with a review of certain decisions relating to its appellate Power under the Constitution. New York: Matthew Bender \& Company, 1913. p. 64-74.

${ }^{164}$ CAPPELLETTI, Mauro. O controle judicial de constitucionalidade das leis no direito comparado. Trad. Aroldo Plínio Gonçalves, com revisão de José Carlos Barbosa Moreira. Porto Alegre: Sergio Antonio Fabris, 1984. p. 75.

${ }^{165}$ A doutrina norte-americana divide a história da Suprema Corte em basicamente quatro fases (1790-1801, 1801-1816, 1816-1835 e 1835-1850). A fase correspondente ao período compreendido entre 1790 a 1801 é caracterizada pelas primeiras decisões da Corte à luz da Constituição America. Mas o período seguinte (1801-1816) é o que marca, através da atuação de Marshall, a efetiva assunção do controle de constitucionalidade pelo Poder Judiciário. Cf. CARSON, Hampton L. The history of the Supreme Court of the United States with all the Chief and Associate Justices. Philadelhia: P. W. Ziegler, 1891. v. 1, p. 205 e s.

${ }^{166}$ O'BRIEN, David M. Constitutional law and politics: civil rights and civil liberties, cit., p. 119.
} 
político e jurídico encontraram, como encontram, dificuldade de assimilar que o Poder Judiciário tenha assumido o papel de intérprete das grandes decisões políticas, inserindo-se no plano do poder soberano, antes reservado apenas ao Poder Legislativo e ao Poder Executivo.

As "questões políticas", como informa Pierre Vialle, resultaram, pois, de uma "tensão permanente" entre o controle de constitucionalidade do sistema americano e o princípio da separação de poderes. ${ }^{167}$

Não surpreende, portanto, que o controle de constitucionalidade pelo Poder Judiciário tenha gerado uma intensa discussão sobre a sua "expansão global" e sobre a “judicialização da política”. Este imenso poder político conferido aos magistrados no exercício do controle de constitucionalidade ensejou inúmeras reações, chegando mesmo a se afirmar, com preocupação, a existência de "governos de juízes" e de "oligarquia de juízes" nos EUA. ${ }^{168}$

A mesma reação foi observada na Itália, na França e na Espanha, a partir dos anos 1990, ante o enfrentamento, pelos magistrados, das grandes controvérsias políticas. ${ }^{169}$ Evidentemente, os demais detentores do poder estatal iniciariam um movimento de contenção e restrição dos poderes dos magistrados.

Ocorre que, nos EUA, a denominada "questão política" sofreu, de há muito, abalo fortíssimo, na medida em que a Suprema Corte foi concitada, e examinou inúmeras questões relativas ao processo eleitoral, inclusive no que tange à eleição do Presidente dos Estados Unidos. ${ }^{170} \mathrm{Se}$ ao Poder Judiciário se confere o exercício da fiscalização do processo eleitoral, bem como o julgamento das diversas demandas eleitorais, de cunho eminentemente político, ${ }^{171}$ não mais se justificaria a adoção da expressão "questões políticas" na atividade jurisdicional.

\footnotetext{
${ }^{167}$ VIALLE, Pierre. La Cour Supreme et la representation politique aux Etats-Unis: nouvel essai sur le gouvernement des juges. Paris: Librairie Générale de Droit et de Jurisprudence, 1972. p. 53-54.

${ }^{168}$ BERGALLI, Roberto. Estado democrático y cuestión judicial: vias para alcanzar una auténtica y democrática independencia judicial, cit., p. 33-39.

${ }^{169}$ GUARNIERI, Carlo; PEDERZOLI, Patrizia. The power of judges: a comparative study of courts and democracy. Oxford; New York: Oxford University Press, 2003. p. 185-196.

${ }^{170}$ VIALLE, Pierre. La Cour Supreme et la representation politique aux Etats-Unis: nouvel essai sur le gouvernement des juges, cit., p. 51-53.

${ }^{171}$ Sobre a distinção entre direitos políticos e direitos da pessoa, realizada pela doutrina norte-americana, cf. COXE, Brinton. An essay on judicial power and unconstitutional legislation, being a commentary on parts of the Constitution of the United States. Philadelphia: Kay and Brother, 1893. p. 118 e s.
} 
Por outro lado, as expressões "questões políticas", "governo de juízes" e “oligarquia de juízes" são por demais simplistas. Da forma como formuladas, tais expressões não designam, com precisão, o fenômeno da assunção do controle de constitucionalidade pelo Poder Judiciário, originário da escolha soberana do poder constituinte originário. $\mathrm{O}$ controle de constitucionalidade não constitui, evidentemente, ato de imposição da vontade dos órgãos jurisdicionais sobre as demais formas de expressão do poder estatal. Trata-se de dever constitucional explicitamente conferido ao Poder Judiciário por ocasião da instituição do próprio Estado.

De outro vértice, a expressão "governo dos juízes" não pode ser considerada adequada, posto que os magistrados têm uma missão política, consistente em fazer respeitar os princípios democráticos e a liberdade que a soberania popular quis exprimir na Constituição. ${ }^{172}$

Estamos de acordo com Eugenio Raúl Zaffaroni, para quem a verdadeira crítica que se faz aos magistrados é a sua eventual quebra de imparcialidade, decorrente de vinculação partidária. ${ }^{173}$ De fato, a partir do momento em que os órgãos jurisdicionais cumprem funções políticas, não podem deixar de ser politizados. ${ }^{174}$ Entretanto, esta politização se prende à vinculação aos objetivos do Estado, todos destinados à satisfação do bem comum. A quebra da imparcialidade, outrossim, representa o desvio de consciência do julgador, o seu deslocamento dos objetivos do Estado para o campo dos interesses particulares.

Mas a regra de imparcialidade é tão antiga como a própria noção de juiz. A quebra de imparcialidade resolve-se através de mecanismos de sanção empregados contra o magistrado que, individualmente, afastou-se de seu compromisso constitucional. Há outrossim, mecanismos processuais de invalidação dos atos praticados por magistrados que se desviem do dever de imparcialidade.

Não se pode pretender, portanto, alterar completamente o sistema de controle de constitucionalidade, ou mesmo restringir os poderes dos juízes, conquistados após longeva experiência política das nações, sob o fundamento de que se pretende extirpar o conteúdo político do Poder Judiciário. Há de se ter a percepção de que as influências

\footnotetext{
${ }^{172}$ POUILLE, André. Le pouvoir judiciaire et les tribunaux. Paris: Masson, 1985. p. 13-14.

${ }^{173}$ ZAFFARONI, Eugenio Raúl. Poder Judiciário: crise, acertos e desacertos. Trad. Juarez Tavares. São Paulo: Ed. Revista dos Tribunais, 1995. p. 95.

${ }^{174}$ ZAFFARONI, Eugenio Raúl. Poder Judiciário: crise, acertos e desacertos, cit., p. 94.
} 
diretas da política no estabelecimento da Constituição causam reflexos diretos na estrutura e no âmbito de competência do Poder Judiciário. ${ }^{175}$

A partir do momento em que o Poder Judiciário passou a exercer o controle de constitucionalidade, tornou-se um órgão eminentemente político, detentor do poder soberano. Os integrantes do Poder Judiciário converteram-se em titulares do poder do Estado. Os magistrados são, portanto, a personificação do Estado no exercício do seu poder.

A jurisdição, como destaca de forma precisa Cândido Rangel Dinamarco, "não é um poder; mas o próprio poder estatal, que é uno, enquanto exercido com os objetivos do sistema processual". 176

O que determina a atuação do Poder Judiciário, como forma de expressão do poder estatal, é a salvaguarda pró-ativa do bem comum. E, neste sentido, a tese substancialista afirma que a justiça constitucional deve assumir uma postura intervencionista. Não se trata de "judicialização da política" e das relações sociais, mas do cumprimento dos preceitos e princípios ínsitos aos direitos fundamentais sociais e ao núcleo político do Estado social previsto na Constituição de $1988 .{ }^{177}$

Esta atividade, em si mesma, como adverte John Aneurin Grey Griffith, "cria uma hipótese política de grande magnitude". ${ }^{178}$

De fato, ao interpretar a Constituição, o órgão jurisdicional se vê na contingência de captar o sentido e o alcance das normas constitucionais. A clareza da lei não traz maiores reflexos para a atividade do julgador, mas a dificuldade de sua interpretação pode dar ensejo à construção do direito, tarefa inexorável do Poder Judiciário.

Esta tarefa, entretanto, não é uma opção do Poder Judiciário, mas decorre de ato soberano e constitucionalmente vinculado.

\footnotetext{
${ }^{175}$ RIGANO, Francesco. Costituzione e potere giudiziario: ricerca sulla formazione delle norme costituzionali. Padova: Cedam, 1982. 315 p.

${ }^{176}$ DINAMARCO, Cândido Rangel. Instituições de direito processual civil. São Paulo: Malheiros Ed., 2001. v. 1, p. 294.

${ }^{177}$ STRECK, Lenio Luiz. O papel da jurisdição constitucional na realização dos direitos sociais-fundamentais. In: SARLET, Ingo Wolfgang (Org.). Direitos fundamentais sociais: estudos de direito constitucional, internacional e comparado. Rio de Janeiro: Renovar, 2003. p. 169-213.

${ }^{178}$ GRIFFITH, John Aneurin Grey. The politics of the Judiciary. 4. ed. London: Fontana, 1991. p. 317-318.
} 
Afirma, então, José Reinaldo de Lima Lopes, que houve um nítido enfraquecimento, após a assimilação do controle de constitucionalidade pelo Poder Judiciário, da distinção entre as esferas política e jurídica. ${ }^{179}$

Nós, contudo, preferimos afirmar que esta questão perdeu completamente o sentido nos países em que, como o Brasil, se adotou o sistema de controle jurisdicional de constitucionalidade. Como um novo patamar de hierarquia constitucional foi estabelecido, a jurisdição constitucional objetiva a manutenção da integridade do sistema, absorvendo todas as questões conflituosas do Estado brasileiro. E, dentro deste quadro, segue-se a mesma lógica do moderno constitucionalismo europeu, cuja proposta central é a proteção dos direitos humanos. ${ }^{180}$

Entretanto, outro fenômeno, decorrente da transição do Estado liberal para o Estado social, iria novamente colocar em pauta o alcance da atividade do Poder Judiciário no Estado de Direito

\section{A constitucionalização dos programas de ação do Estado}

A assunção do controle de constitucionalidade pelo Poder Judiciário foi acompanhada de outro fenômeno de grande relevância, e que teria fortes implicações na discussão acerca do real sentido da teoria da separação dos poderes.

Após a edição da Declaração Universal dos Direitos Humanos, em 1948, os diversos países signatários passaram a intensificar os movimentos de implantação de programas que pudessem viabilizar a consecução dos direitos fundamentais sociais. Por direitos fundamentais sociais deve-se entender aqueles destinados a garantir as necessidades básicas da população, permitindo uma melhor distribuição de recursos. Abrangem toda uma experiência social e permitem a participação na esfera social. ${ }^{181}$

O processo de democratização dos países foi proporcional à institucionalização dos direitos fundamentais sociais, muito embora as suas garantias tenham sido, nos países subdesenvolvidos, muito mais de cunho formal. Era indispensável, portanto, a

\footnotetext{
${ }^{179}$ LOPES, José Reinaldo de Lima. Direitos sociais: teoria e prática. São Paulo: Método, 2006. p. 124.

${ }^{180}$ SWEET, Alec Stone. Governing with judges: constitutional politics in Europe. Oxford: Oxford University Press, 2000. p. 29.

${ }^{181}$ CAMPBELL, Tom; GOLDSWORTHY, Jeffrey; STONE, Adriene. Protecting human rights: instruments and institutions. Oxford: Oxford University Press, 2005. p. 323-337.
} 
institucionalização de programas de atuação estatal, capazes de direcionar a conduta dos órgãos do Estado para a satisfação espontânea dos direitos fundamentais.

As Constituições dos Estados passaram a disciplinar, normativamente, programas de ação estatal. Ao passo em que os direitos sociais eram politicamente garantidos, mediante declaração expressa dos bens jurídicos que protegiam, as Constituições igualmente estabeleceram os mecanismos formais de implementação destes direitos.

Surgiam, portanto, as normas programáticas, ${ }^{182}$ constitutivas dos núcleos constitucionais de irradiação dos direitos fundamentais. ${ }^{183}$

Observa Oscar Vilhena Vieira que a enorme estrutura de normas diretivas e programáticas dificulta o cumprimento das atribuições dos tribunais e das cortes constitucionais, ante a sua peculiaridade. ${ }^{184}$

Com efeito, a tarefa prevista para o Poder Judiciário no Estado liberal estava bem delimitada: aplicar a lei ao caso concreto, evitando a interferência das demais formas de expressão do poder estatal na esfera de liberdade dos cidadãos. Nesta tarefa, os magistrados não deveriam ampliar o alcance da lei, posto que a legitimidade constitucional para a sua criação e para a sua interpretação era do legislador. Os tribunais, por conseguinte, eram reputados legisladores negativos, segundo a concepção kelseniana. ${ }^{185}$

Não se imaginava que o Estado poderia assumir, no futuro, atribuição ativa, destinada à realização material de direitos sequer imaginados à época. Não se concebia, igualmente, que as futuras Constituições, sob a égide do Estado social, seriam informadas por normas descritivas de programas de atuação estatal, ${ }^{186}$ atraindo para o universo jurídico condutas historicamente aneladas à atuação exclusiva do legislador e do administrador.

\footnotetext{
${ }^{182}$ Sobre o conceito das normas programáticas, cf. CANOTILHO, José Joaquim Gomes. Constituição dirigente e vinculação do legislador: contributo para a compreensão das normas constitucionais Programáticas. Coimbra: Coimbra Ed., 1994. p. 297 e s.

${ }^{183}$ Ver supra, Capítulo I, Seção 9.

${ }^{184}$ VIEIRA, Oscar Vilhena. Supremo Tribunal Federal: jurisprudência política. São Paulo: Ed. Revista dos Tribunais, 1994. p. 31-38.

${ }^{185}$ VIEIRA, Oscar Vilhena. Supremo Tribunal Federal: jurisprudência política, cit.

${ }^{186}$ Fábio Konder COMPARATO afirma que os direitos fundamentais sociais (direitos econômicos, sociais e culturais) objetivam "estabelecer uma igualdade básica de condições de vida", o que pressupõe o estabelecimento de um "trabalho de programação". Daí o conflito entre tais direitos e a lógica capitalista. E conclui o referido autor: "O Estado contemporâneo não é mais o Estado da lei. A produção do Estado contemporâneo é sobretudo de políticas, ou seja, de programas de ação governamental" (COMPARATO, Fábio Konder. Prestação, promoção e violação dos direitos econômicos, sociais e culturais: a responsabilidade do Estado no direito interno e no direito internacional. In: ENCONTRO BRASILEIRO DE DIREITOS HUMANOS, 1., cit., p. 130-139).
} 
Enquanto as atividades de programação e execução das finalidades do Estado permaneceram sob o enfoque exclusivamente político, nenhuma crise se instaurou no panorama do controle de constitucionalidade. Entretanto, com a inserção das normas programáticas no bojo das Constituições, o Poder Judiciário foi chamado a decidir a compatibilidade dos atos comissivos e omissivos das demais formas de expressão do poder estatal, muitas vezes envolvendo a análise dos critérios de escolha do administrador em cotejo com a finalidade do ato administrativo.

Houve, portanto, uma alteração na percepção do papel da magistratura, porquanto a análise dos direitos fundamentais sociais invadiu as chamadas "controvérsias de classe", o que exigiu um certo grau de criatividade e ativismo judiciários. ${ }^{187}$

No Brasil, uma das primeiras questões sensíveis enfrentadas pelos tribunais foi a da admissibilidade do exame judicial do mérito dos atos administrativos. A doutrina e a jurisprudência mantiveram, por muitos anos, o entendimento de que o mérito do ato administrativo, pelo seu conteúdo eminentemente discricionário, não poderia ser apreciado pelo Poder Judiciário, sob pena de violação do princípio da separação de poderes. ${ }^{188} \mathrm{O}$ postulado em questão, contudo, foi substancialmente mitigado pela teoria do desvio do poder e pela teoria dos motivos determinantes. ${ }^{189}$ Após a inserção do princípio da moralidade no caput do art. 37 da Constituição Federal, ampliou-se ainda mais o campo de análise do mérito do ato administrativo pelo Poder Judiciário, em cotejo com o princípio da legalidade.

Nota-se, portanto, a absorção cada vez maior dos componentes políticos da sociedade pelo ordenamento jurídico. ${ }^{190}$ Há uma tendência indisfarçável de vinculação de

\footnotetext{
${ }^{187}$ CAPPELlETTI, Mauro. Juízes legisladores? Trad. Carlos Alberto Alvaro de Oliveira. Porto Alegre: Sergio Antonio Fabris, 1993. p. 56-60.

${ }^{188}$ Cf. FAGUNDES, Miguel Seabra. O controle dos atos administrativos pelo Poder Judiciário. 7. ed. Rio de Janeiro: Forense, 2006. p. 179-193.

${ }^{189}$ DI PIETRO, Maria Sylvia Zanella. Direito administrativo, cit., p. 202-204.

${ }^{190}$ O Supremo Tribunal Federal já rejeitou a análise dos critérios para a expulsão de estrangeiro por ato do Presidente da República, ao fundamento de que se tratava de ato político, da esfera privativa do Poder Executivo (Habeas corpus n. $^{\circ} 49.412$, de 1972). O posicionamento foi alterado, em 1991, admitindo-se a nulidade do ato político por ilegalidade (STF $-\mathrm{HC} \mathrm{N} .^{\circ}$ 68.402). O Supremo Tribunal Federal, por diversas ocasiões, repeliu a prática de atividade legiferante pelo Poder Judiciário, enunciando o princípio do legislador negativo (ADIMCQ n. ${ }^{\circ} 1.063$ - DF e RE n. ${ }^{\circ}$ 181.138). Já em 1963, o Supremo Tribunal Federal, no Recurso em Mandado de Segurança n. $^{\circ} 11.140$, relatado pelo Ministro Luiz Gallotti, embora reconhecendo que as "medidas políticas são discricionárias", limitou tal discricionariedade aos limites constitucionais ou legais, justificando a interveniência do Poder Judiciário no caso de extrapolação. Em questões que se referem ao respeito à vida, o STF reconheceu o dever do Estado de fornecer gratuitamente medicação a portadores do vírus HIV, sob o fundamento de que os poderes públicos devem praticar políticas sociais e econômicas que visem à consecução dos objetivos proclamados no art. 196 da Constituição Federal, invocando precedentes consolidados da Corte (RE - 271.286 e AgRg 271.286).
} 
todos os atos das formas de expressão do poder estatal às finalidades do Estado. Quaisquer condutas praticadas por agentes da administração, que se desviem dos objetivos estatais, estarão sujeitas ao controle de constitucionalidade pelo Poder Judiciário.

As condutas descritas na Constituição Federal, tendentes à realização dos direitos fundamentais sociais, constituem as chamadas políticas públicas e são direcionadas pelos núcleos constitucionais de irradiação daqueles direitos. Os núcleos de irradiação, entretanto, estão vinculados aos objetivos do Estado, consignados no art. $3^{\circ}$ da Constituição Federal. ${ }^{191}$

A conduta comissiva do Poder Legislativo e do Poder Executivo, violadora das normas constitucionais programáticas, não representou, entretanto, maiores dificuldades no panorama jurídico, uma vez que o Poder Judiciário dispõe de instrumentos constitucionais bastantes para a invalidação dos atos e a responsabilização dos agentes. ${ }^{192}$ A doutrina da invalidade dos atos administrativos e o exame de constitucionalidade dos atos do Poder Legislativo são campos férteis para a solução dos inúmeros problemas oriundos das condutas comissivas dos agentes públicos no exercício de políticas públicas vinculadas à satisfação dos direitos fundamentais sociais.

Maiores entraves à atividade jurisdicional foram observados na análise do comportamento omissivo dos agentes públicos.

\footnotetext{
Consta do texto da ementa do $\mathrm{AgRg} 271.286$ a afirmação de que "a interpretação da norma programática não pode transformá-la em promessa constitucional inconsequente" (Ministro Celso de Mello). Tal entendimento foi adotado pelo Superior Tribunal de Justiça em diversas oportunidades, ressaltando-se, em diversos casos, a integralidade da assistência à saúde pelo Estado, de forma individual ou coletiva (REsp 212346 AgRg no Ag 842866, REsp 814076, REsp 807863 AgRg no REsp 757012, REsp 684646, REsp 658323 AgRg na STA 83, RMS 17425, REsp 625329, MS 8895, REsp 509753, MS 8740, REsp 430526, REsp 338373, RMS 13452, RMS 11.183 e RMS 11.129). O mesmo fundamento foi invocado pelo Supremo Tribunal Federal para a análise de políticas públicas de educação na ADI 319, reconhecendo ao Estado legitimidade para, com fundamento na defesa do consumidor e na redução das desigualdades sociais, em conformidade, ainda, com os ditames da justiça social, regular política de preços em face da arbitrariedade do aumento dos lucros pelo poder econômico. Cf. SANTOS, Marília Lourido dos. Interpretação constitucional no controle judicial das políticas públicas. Porto Alegre: Sergio Antonio Fabris, 2006. p. 73 e ss.

${ }^{191}$ Vide supra, Capítulo I, Seção 8.

${ }^{192} \mathrm{Cf}$. a seguinte decisão do Supremo Tribunal Feral: "Cabe ao Poder Judiciário verificar a regularidade dos atos normativos e de administração do Poder Público em relação às causas, aos motivos e à finalidade que os ensejam. Pelo princípio da proporcionalidade, há que ser guardada correlação entre o número de cargos efetivos e em comissão, de maneira que exista estrutura para atuação do Poder Legislativo local" (RE 365.368- AgR, Rel. Min. Ricardo Lewandowski, julgamento em 22-5-07, $D J$ de 29-6-07).
} 


\section{Lesão causada aos direitos fundamentais sociais pelas omissões do Estado}

A cristalização de programas de ação governamental em normas constitucionais causou grande impacto na abordagem do âmbito de atuação do Poder Judiciário. A jurisdição sempre esteve ambientada com o problema da invalidação dos atos jurídicos administrativos, de maneira que as políticas públicas, sob o prisma da conduta comissiva dos agentes públicos, puderam ser perfeitamente dimensionadas no sistema do Direito Administrativo, ${ }^{193}$ fundado nos princípios inscritos no caput do art. 37 da Constituição Federal, e no sistema de controle de constitucionalidade.

Ocorre que os núcleos constitucionais de irradiação contêm normas que vinculam os agentes públicos a condutas ativas. É o caso, exemplificativamente, do art. 227, caput, da Constituição Federal, que estabelece o dever de o Estado dispensar proteção integral e prioritária às crianças e aos adolescentes. Dentro do âmbito de proteção integral à criança e ao adolescente, o $\S 1^{\circ}$ do art. 227 da Constituição Federal estabelece que o Estado promoverá programas de assistência integral à saúde.

Por força da irradiação contida no núcleo constitucional (CF, art. 227), editou-se a Lei $n^{\circ}$ 8.069/90, o Estatuto da Criança e do Adolescente. Os direitos fundamentais sociais à vida e à saúde foram reiterados no art. $7^{\circ}$ do ECA, com comando subconstitucional de que políticas sociais públicas deverão permitir o desenvolvimento sadio e harmonioso das crianças e dos adolescentes, em condições dignas de existência. O art. 11, $\S 1^{\circ}$, do ECA dispõe, nesta esteira, que crianças e adolescentes portadores de deficiência receberão atendimento especializado.

O direito fundamental social à saúde está assegurado no art. $6^{\circ}$ da Constituição Federal e foi reiterado no art. $7^{\circ}$ do ECA. O núcleo constitucional de irradiação, materializado no art. 227, caput, e seu $\S 1^{\circ}$, produziu os efeitos legislativos esperados, consoante inferência que se faz da leitura do art. $11, \S 1^{\circ}$, do ECA. Do ponto de vista formal, o direito fundamental social foi assegurado e existem possibilidades jurídicas plenas de irradiação no plano material.

\footnotetext{
${ }^{193}$ Sobre a invalidação dos atos administrativos, cf. MEIRELLES, Hely Lopes. Direito administrativo brasileiro. 16. ed. São Paulo: Ed. Revista dos Tribunais, 1991. p. 177 e s, MELLO, Celso Antônio Bandeira de. Curso de direito administrativo, cit., p. 427 e s, DI PIETRO, Maria Sylvia Zanella. Direito administrativo, cit., p. 217 e s.
} 
Entretanto, para a satisfação espontânea do direito fundamental social das crianças e dos adolescentes, é necessário que os agentes públicos, através de políticas públicas específicas, promovam os atos necessários para a implantação do tratamento especializado a ser dispensado aos portadores de deficiência. Desde a concepção legislativa dos estabelecimentos especializados até a contratação de profissionais capacitados e a aquisição de bens e equipamentos necessários ao tratamento das deficiências, deverão ser promovidos diversos atos legislativos e administrativos, de ampla complexidade, constitutivos de políticas públicas destinadas à satisfação dos bens da vida previstos no art. $6^{\circ}$ da Constituição da República e no art. $7^{\circ}$ do ECA.

A questão fundamental, no que tange à atividade do Poder Judiciário, lastreia-se na hipótese de omissão do Estado, de forma que as crianças e os adolescentes portadores de deficiência física de um determinado município brasileiro não tenham qualquer atendimento especializado. Neste caso, embora exista a plena irradiação do núcleo constitucional, o Estado não desenvolveu os inúmeros e complexos atos necessários para a satisfação espontânea do direito fundamental social.

Ora, se o Estado não promoveu a satisfação espontânea do bem da vida saúde, está-se diante de uma lesão aos direitos das crianças e dos adolescentes. Nasce para os titulares do direito a pretensão e, por via de consequência, poderão utilizar-se do direito constitucional de ação para obter a reparação da lesão causada.

Imprescindível, para a compreensão da atuação do Poder Judiciário, na hipótese de omissão do Estado, estabelecer-se a distinção clara entre direito subjetivo assegurado constitucionalmente, que confere ao seu titular uma posição de vantagem em relação ao bem da vida, ${ }^{194}$ e os mecanismos para a satisfação espontânea destes direitos. ${ }^{195}$

Na hipótese ora tratada, o direito constitucional subjetivo consubstancia-se na norma inserta no art. $6^{\circ}$ da Constituição Federal, de resto reiterada pelo art. $7^{\circ}$ do ECA. O bem da vida tutelado é a saúde da criança e do adolescente. Mencionado direito fundamental social sustenta a relação jurídica havida entre o Estado e os titulares. Esta relação jurídica é de cunho obrigacional, decorrente de vinculação constitucional do Estado.

\footnotetext{
${ }^{194}$ ATTARDI, Aldo. L'interesse ad agire. Padova: CEDAM, 1958. p. 86-92.

${ }^{195}$ Vide supra, Capítulo I, Seções 4, 8 e 9.
} 
O Estado, portanto, tem o dever constitucional de proporcionar saúde, em seu aspecto pleno, às crianças e aos adolescentes. As opções de que dispunha o Estado eram as traçadas no núcleo constitucional de irradiação materializado no art. 227 , caput, e $\S 1^{\circ}$, da Constituição da República. Embora o Estado tenha levado a efeito a irradiação formal dos direitos fundamentais, através do art. $11, \S 1^{\circ}$, da Lei $\mathrm{n}^{\circ} 8.069 / 90$, não completou o ciclo, deixando de promover a irradiação material, mediante a consecução de políticas públicas direcionadas para a satisfação espontânea do bem jurídico saúde.

Houve, portanto, lesão ao direito fundamental das crianças e dos adolescentes do município. De acordo com o disposto no art. $5^{\circ}$, inciso XXXV, da Constituição Federal, a lesão, ou mesmo ameaça de lesão, a direito habilita o titular a pleitear a atuação do Poder Judiciário.

Faz-se necessária, entretanto, uma correta interpretação do princípio da separação de poderes, à luz do Estado social, a fim de que não se o invoque como fundamento para a não-efetivação dos direitos fundamentais sociais.

\section{Alcance do art. $2^{\circ}$ da Constituição Federal de 1988}

A estabilidade objetivada no Estado liberal é substituída pelo dirigismo estatal, alterando-se, de forma profunda, a concepção da teoria da separação dos poderes. ${ }^{196}$ Dentro deste quadro, o Estado existe para atender ao bem comum, o que representa a satisfação espontânea dos direitos fundamentais. Em última análise, o Estado deve promover a igualdade substancial dos cidadãos, mediante a implementação material, e não meramente formal, dos bens da vida amparados pelos direitos fundamentais sociais. Ao assim laborar, o Estado garante não somente a democracia política, mas também a democracia social.

Para atingir tais objetivos, faz-se necessário o estabelecimento de metas e de programas a serem executados, afim de que os direitos fundamentais sejam satisfeitos espontaneamente.

Formulado o comando constitucional, gerador dos núcleos constitucionais de irradiação, cumpre ao Estado a promoção das ações necessárias para a implementação dos

${ }^{196}$ COMPARATO, Fabio Konder. Ensaio sobre juízo de constitucionalidade de políticas públicas, cit., p. 1617. 
objetivos traçados no art. $3^{\circ}$ da Constituição Federal. Ao atender aos objetivos constitucionalmente estabelecidos, o Estado satisfaz espontaneamente os direitos fundamentais, em especial os de caráter social.

O poder estatal, caracteristicamente uno, há de ser utilizado finalisticamente. Embora uno, o poder é exercido segundo um critério funcional, ${ }^{197}$ pelo que a estrutura normativa da Constituição dispõe sobre suas três formas de expressão, tanto assim consideradas as atividades legislativa, executiva e jurisdicional.

As formas de expressão do poder estatal são, por conseguinte, instrumentos para a consecução dos fins do Estado, de forma que não podem ser consideradas como um fim em si mesmas. Assim concebidas, as formas de expressão do poder estatal não diferem em grau de importância. Todas estão no mesmo patamar constitucional e aneladas ao mesmo fim. Quebra-se, pois, o postulado da atividade legislativa como sendo a preponderante sobre os demais poderes, característica observada no Estado liberal.

Não há, portanto, nenhuma prevalência de qualquer forma de expressão do poder estatal sobre outra. Existe, outrossim, uma especialização de atividades, criada exclusivamente para o atendimento aos fins do Estado.

Pela própria natureza dos fins do Estado, preponderantemente agregada ao objetivo de igualdade substancial entre os cidadãos, as políticas públicas para a respectiva concretização demandam a concorrência prioritária do Poder Legislativo e do Poder Executivo. As políticas públicas para a satisfação dos direitos fundamentais, portanto, constituem, preponderantemente, atividades legislativas e administrativas.

Dentro do âmbito de suas atribuições, as formas de expressão do poder estatal são independentes entre si, ou seja, gozam de autonomia constitucional para o exercício de suas funções. Esta independência, todavia, estará sempre limitada a uma compatibilização com a Constituição.

Enquanto a realização de políticas públicas é tarefa preponderante do Poder Legislativo e do Poder Executivo, cumpre ao Poder Judiciário examinar a compatibilização dos seus atos com a Constituição, mediante o exercício do controle de constitucionalidade.

\footnotetext{
${ }^{197}$ GRINOVER, Ada Pellegrini. A responsabilidade do juiz brasileiro. In: Estudos de direito processual em homenagem a José Frederico Marques. São Paulo: Saraiva, 1982. p. 3-7.
} 
O Poder Judiciário, no exercício do controle de constitucionalidade, vela pela observância irrestrita da independência constitucional das formas de expressão do poder estatal, mediante aplicação do disposto no art. $2^{\circ}$ da Constituição Federal.

A independência de que trata a Constituição deve ser compreendida como a garantia de que a forma de expressão do poder estatal não terá invadida sua esfera de competência exclusiva. Entretanto, o âmbito de competência de cada forma de expressão do poder é ditado pela própria Constituição, de forma que, exercendo o controle de constitucionalidade, é o Poder Judiciário quem irá delimitá-lo. ${ }^{198}$

Como todos os atos dos agentes públicos devem estar vinculados aos objetivos do Estado, as formas de expressão do poder estatal devem atuar de forma integrada, evitando-se conflitos na consecução do art. $3^{\circ}$ da Constituição Federal. A harmonia dos poderes, por conseguinte, consiste na plena integração das atividades de sua competência para o atendimento dos objetivos do Estado.

A conduta dos agentes públicos, no exercício de políticas públicas, entretanto, pode contrariar os objetivos do Estado. Esta contrariedade resultará de uma conduta comissiva ou omissiva. A conduta comissiva será alvo de controle de constitucionalidade pelo Poder Judiciário, segundo os mecanismos de invalidação dos atos à disposição no ordenamento jurídico.

Enquanto a conduta comissiva dos agentes públicos, violadoras dos objetivos do Estado, necessitam de invalidação, as condutas omissivas demandam integração. Esta integração é indispensável para que os objetivos do Estado, e a própria satisfação dos direitos fundamentais, não dependam do arbítrio das injunções político-partidárias do momento. A integração da atividade estatal, nas hipóteses de omissão pelas outras formas de expressão do poder, é, pois, atividade inerente ao Poder Judiciário.

Não se fala, outrossim, em independência das formas de expressão do poder estatal que se destine a contrariar as suas obrigações constitucionais, uma vez que a independência somente deverá ser reconhecida no exercício dos objetivos traçados no art. $3^{\circ}$ da Constituição Federal. A independência das formas de expressão do poder estatal,

\footnotetext{
${ }^{198}$ O Supremo Tribunal Federal já reconheceu, em análise ao art. $2^{\circ}$ da $\mathrm{CF}$, a impossibilidade de o Poder Judiciário atuar como legislador positivo (MS 22.690, Rel. Min. Celso de Mello, julgamento de 17/04/97, DJ de 7/12/06), bem como a aplicabilidade estrita ou materialmente inelástica do esquema de freios e contrapesos (ADI 2.911, Rel. Min. Carlos Britto, julgamento em 10/08/06, DJ de 02/02/07).
} 
portanto, não pode ser invocada para o descumprimento das obrigações que a Constituição lhes impôs.

A omissão das formas de expressão do poder estatal representa a quebra do compromisso com os objetivos do Estado. ${ }^{199}$ Como a harmonia entre os poderes objetiva o atendimento integral dos objetivos estatais, cumpre ao Poder Judiciário, através da jurisdição, restabelecer a harmonia, mediante a integração da conduta omissiva dos agentes públicos.

Tércio Sampaio Ferraz Júnior afirma que o objetivo do Estado liberal era o de neutralizar o Poder Judiciário frente aos demais poderes, ${ }^{200}$ afirmação que guarda sintonia com o posicionamento de Fábio Konder Comparato, para quem o liberalismo adotou os ideais clássicos de "repouso" e de "inação". 201

Ora, se o Poder Judiciário, como forma de expressão do poder estatal, deve estar alinhado com os escopos do próprio Estado brasileiro, não mais se pode falar em uma neutralização de sua atividade, a partir da interpretação do art. $2^{\circ}$ da Constituição Federal. Ao revés, o Poder Judiciário encontra-se constitucionalmente vinculado à política estatal e, por via de consequência, este é um conceito que deverá obrigatoriamente integrar a teoria jurídica. $^{202}$

Política, a nosso juízo, é o conjunto de atividades do Estado tendentes à consecução de seus fins. Ajusta-se ao conceito de standard, ou meta a ser atingida. Trata-se de um conjunto de normas (Poder Legislativo), atos administrativos (Poder Executivo) e decisões (Poder Judiciário) tendentes à realização dos fins primordiais do Estado. ${ }^{203}$

\footnotetext{
${ }^{199}$ A omissão legislativa levou à concepção, na Alemanha, em Portugal e na Itália, do princípio da proibição do retrocesso social, pelo qual é vedado ao legislador suprimir a fruição de um direito fundamental social, sem que sejam criados mecanismos de compensação. Sobre a adoção deste princípio no Brasil, cf. DERBI, Felipe. A aplicabilidade do princípio da proibição do retrocesso social no direito brasileiro. In: SOUZA NETO, Cláudio Pereira de; SARMENTO, Daniel (Coords.). Direitos sociais: fundamentos, judicialização e direitos sociais em espécie. Rio de Janeiro: Lumen Juris, 2008. p. 343-382.

${ }^{200}$ FERRAZ JUNIOR, Tercio Sampaio. O Judiciário frente à divisão dos poderes: um princípio em decadência? Revista USP, São Paulo, n. 21, p. 14, mar./maio 1994.

${ }^{201}$ COMPARATO, Fabio Konder. Ensaio sobre juízo de constitucionalidade de políticas públicas, cit., p. 1617.

${ }^{202}$ Cf. DWORKIN, Ronald. Taking rights seriously. Cambrige: Massachusetts, 1978.

${ }^{203}$ Nas palavras de Fábio Konder COMPARATO: "Uma lei, editada no quadro de determinada política pública, por exemplo, pode ser inconstitucional, sem que esta última o seja. Inversamente, determinada política governamental, em razão da finalidade por ela perseguida, pode ser julgada incompatível com os objetivos constitucionais que vinculam a ação do Estado, sem que nenhum dos atos administrativos, ou nenhuma das normas que a regem, sejam, em si mesmos, inconstitucionais" (COMPARATO, Fabio Konder. Ensaio sobre juízo de constitucionalidade de políticas públicas, cit., p. 18-19).
} 
A Constituição Federal de 1988, inserida no modelo dirigente (CF, art. $3^{\circ}$ ), sem dúvida alguma exige do Poder Judiciário não uma "repolitização" - expressão referida por Tércio Sampaio Ferraz Júnior - mas uma atualização dos conceitos jurídicos à luz dos fins do Estado.

Compreendemos que o magistrado, exercitando atividade jurisdicional em um Estado do bem-estar social, deve redimensionar o seu foco de análise, investigando o fundamento de todos os atos estatais a partir dos objetivos fundamentais inseridos na Constituição da República. A Constituição deverá receber uma leitura finalística, de tal forma que o art. $2^{\circ}$, matriz do princípio da independência e da harmonia entre os poderes, deverá ser obrigatoriamente revisitado.

Busca-se, portanto, o afastamento do paradigma liberal na atividade jurisdicional.

Enquanto aos poderes legislativo e executivo cabem atividades caracteristicamente pró-ativas, ao Poder Judiciário incumbe o exame de constitucionalidade e de legalidade dos atos praticados pelos demais poderes. Trata-se, portanto, de atividade jurisdicional corretiva, que não emite juízo de valor sobre a ação dos demais poderes, apenas de compatibilização com as normas constitucionais.

Como toda atividade exercida pelo Poder Executivo e pelo Poder Legislativo deve compatibilizar-se com a Constituição Federal, cabe ao Poder Judiciário analisar, em qualquer situação e desde que provocado ( $\mathrm{CF}$, art. $\left.5^{\circ}, \mathrm{XXXV}\right)$, a constitucionalidade respectiva. Aquilo que se convencionou chamar de "ato de governo" ou "questões políticas" deverá ser examinado pelo Poder Judiciário sob o prisma do atendimento aos fins do Estado (CF, art. $\left.3^{\circ}\right)$.

A atividade integradora do Poder Judiciário, contudo, possui contornos muito específicos, devendo ser corretamente dimensionada, a fim de que haja o necessário equilíbrio de constitucionalidade na atuação das formas de expressão do poder estatal. 


\section{O papel do Poder Judiciário na efetivação dos direitos fundamentais sociais}

\subsection{A adoção do sistema ético de referência como pressuposto de atuação do Poder Judiciário}

Ao se integrar com o sistema normativo internacional de proteção dos direitos humanos, ${ }^{204} \mathrm{o}$ Estado brasileiro adotou o referencial ético que deu origem à Declaração dos Direitos Humanos de 1948. Adotando o sistema ético de referência, o Estado brasileiro optou pela proteção integral e irrestrita dos direitos humanos, mediante a satisfação dos bens soberanos de toda a humanidade. ${ }^{205}$

A institucionalização dos direitos humanos, ${ }^{206}$ mediante a respectiva positivação, implicou na absorção, pela Constituição Federal de 1988, do sistema ético de referência, consoante claramente indica o seu art. $3^{\circ}$. Desta forma, constitui objetivo do Estado brasileiro a efetiva proteção dos direitos fundamentais, através da completa salvaguarda dos bens da vida por eles protegidos.

O Estado brasileiro assumiu, igualmente, o compromisso de manter a democracia como forma de governo. Para a afirmação social da democracia, faz-se necessária a garantia de igualdade material entre todos os cidadãos brasileiros. ${ }^{207}$ Esta igualdade somente poderá ser obtida através da satisfação dos bens da vida previstos no art. $6^{\circ}$ da Constituição Federal, integrantes dos direitos fundamentais sociais.

Os direitos fundamentais sociais, por outro lado, constituem direitos constitucionais subjetivos, ${ }^{208}$ dotados de eficácia plena e de exigibilidade imediata, na forma do que dispõe o art. $5^{\circ}, \S 1^{\circ}$, da Lex Legum. ${ }^{209}$

Os direitos fundamentais sociais não se confundem com o plexo normativo criado pelo Estado para a satisfação espontânea dos bens da vida protegidos, os núcleos constitucionais de irradiação. Tais núcleos constituem norma de conduta dos agentes públicos para a irradiação formal e material dos direitos fundamentais. Esta irradiação

\footnotetext{
${ }^{204}$ Vide supra, Capítulo 1, Seção 6.

${ }^{205}$ Vide supra, Capítulo 1, Seção 2.

${ }^{206}$ Vide supra, Capítulo 1, Seção 3.

${ }^{207}$ Vide supra, Capítulo 1, Seção 7.

${ }^{208}$ Vide supra, Capítulo 1, Seção 4.

${ }^{209}$ Vide supra, Capítulo 1, Seção 10.
} 
ocorre através das chamadas políticas públicas, e sua tendência é a satisfação espontânea, e material, dos bens da vida assegurados pelos direitos fundamentais sociais. ${ }^{210}$

O sistema ético de referência, plasmado no art. $3^{\circ}$ da Constituição Federal, inadmite que os direitos fundamentais sociais não sejam implementados pelas formas expressão do poder estatal. Assim, todas as políticas públicas realizadas pelas formas de expressão do estatal, o que inclui o Poder Judiciário, devem ser direcionadas para a efetivação dos direitos fundamentais sociais.

Decorre do exposto que o Poder Judiciário encontra-se vinculado ao sistema ético de referência, no que tange à efetivação dos direitos fundamentais. Esta vinculação lhe impõe uma concepção mais finalística de sua atividade. O pressuposto de atuação do Poder Judiciário, portanto, é a de realização dos direitos fundamentais, através dos mecanismos processuais à sua disposição. Não poderá, por consequência, manter uma postura meramente contemplativa, ${ }^{211}$ sujeita às arbitrariedades dos demais poderes, de tal forma que, quando concitado, deverá, na apreciação do direito fundamental violado pela omissão do Estado, exercer conduta pró-ativa e corretiva, desde que procedente o pedido.

Oportuna é a observação de Carlo Cardia, segundo a qual há uma percepção, daqueles que vivem em uma condição de empobrecimento crescente, de que os direitos individuais, como a liberdade, sem a efetivação dos direitos fundamentais sociais, são praticamente inúteis. ${ }^{212}$ Desta forma, ao promover a efetivação dos direitos fundamentais sociais, o Poder Judiciário estará enriquecendo a cidadania, mediante a completude dos direitos fundamentais, em uma atitude ética compatível com o sistema.

E é certo que os direitos fundamentais, pelo seu intrínseco conteúdo ético, não serão menos jurídicos. Ao contrário, a sua construção ético-jurídica os retira da chamada “agenda política", em rumo à plena concretização. ${ }^{213}$

Por outro lado, e em arremate à disceptação, lúcida é a observação de Adolfo Trendelenburg, para quem deve existir uma tendência à realização da ética na formulação e

\footnotetext{
${ }^{210}$ Vide supra, Capítulo 1, Seção 8.

${ }^{211}$ Dalmo de Abreu DALLARI aponta, na atuação dos tribunais superiores, a "excessiva condescendência com inconstitucionalidades e ilegalidades praticadas por chefes do Executivo", o que reflete na não-aplicação "dos instrumentos legais já existentes". Postula, então, o eminente autor, por uma "mudança de comportamento" (DALLARI, Dalmo de Abreu. O poder dos juízes, cit., p. 3).

${ }^{212}$ CARDIA, Carlo. Genesi dei diritti umani, cit., p. 76-84.

${ }^{213}$ TASSARA, Andrés Ollero. 50 Anos da Declaração Universal dos Direitos Humanos: o significado dos direitos fundamentais. Revista de Direito Constitucional e Internacional, São Paulo, ano 11, n. 43, p. 5772, abr./jun. 2003.
} 
na positivação do ordenamento jurídico, a fim de que a sua evolução possa, igualmente, observar padrões éticos de aperfeiçoamento. ${ }^{214}$

A efetivação dos direitos fundamentais, em especial os sociais, deve ser o compromisso ético de maior relevância do Poder Judiciário.

\section{2. Âmbito de atuação do Poder Judiciário no caso de lesão aos direitos fundamentais sociais}

Caso o Poder Legislativo ou o Poder Executivo se omitam na realização das políticas públicas necessárias para a efetivação dos direitos fundamentais sociais, cumpre ao Poder Judiciário exercer o controle de constitucionalidade dos seus atos. ${ }^{215}$ Entretanto, para corrigir as omissões das demais formas de expressão do poder estatal, o Poder Judiciário age de forma integradora, através da jurisdição, mas com amplos poderes coercitivos, necessários à concretização do provimento jurisdicional. ${ }^{216}$

Logo, o objetivo da atuação do Poder Judiciário é o de efetivar os direitos fundamentais, mediante a concessão dos bens da vida por eles protegidos. Do plano de observação constitucional, pautada na decisão primária do constituinte, passa-se ao plano técnico-jurídico, mediante a identificação das posições e pretensões jurídicas relativas aos direitos fundamentais a serem tutelados. ${ }^{217}$

Para o perfeito equilíbrio do princípio da separação de poderes, o Poder Judiciário, em princípio, não interfere nos núcleos constitucionais de irradiação e tampouco em suas ramificações. Isto porque os núcleos constitucionais de irradiação são comandos dirigidos exclusivamente ao Poder Legislativo e ao Poder Executivo, não constituindo competência constitucional do Poder Judiciário, salvo no caso de inobservância as posturas constitucionais - controle de constitucionalidade - por aquelas formas de expressão do poder.

Entre a trajetória que se inicia da positivação constitucional do rol de direitos fundamentais, passando pelos núcleos constitucionais de irradiação e pelas políticas

\footnotetext{
${ }^{214}$ TRENDELENBURG, Adolfo. Diritto naturale sulla base dell'etica. Napoli: Jovene, 1873. p. 109 e ss.

${ }^{215}$ Vide supra, Capítulo 2, Seções 2 e 3.

${ }^{216}$ MORTARA, Lodovico. Instituzioni di procedura civile. Firenze: S. A. G. Barbèra, 1937. p. 4.

${ }^{217}$ DALLARI, Dalmo de Abreu. Direitos humanos e cidadania, cit., p. 23-24.
} 
públicas executadas pelas demais formas de expressão do poder estatal, até a satisfação dos bens da vida protegidos, o Poder Judiciário interfere diretamente nos dois extremos.

O Poder Judiciário, pois, deve observar, no princípio da especialização contido na teoria da separação dos poderes, o exercício exclusivo da jurisdição, única atividade que lhe foi constitucionalmente reservada. ${ }^{218}$

No exercício da jurisdição constitucional, evidentemente na modalidade difusa de controle de constitucionalidade, o Poder Judiciário irá se concentrar exclusivamente na detecção do direito subjetivo constitucionalmente assegurado (direitos fundamentais sociais) e na verificação da satisfação, ou não, do bem da vida. Caso o bem da vida reste comprovadamente não-satisfeito, estará configurada lesão ao direito fundamental social ${ }^{219}$ e, por via de consectário lógico, o provimento jurisdicional determinará a respectiva reparação.

Dentro deste prisma de análise, ao Poder Judiciário cabe o exame da existência da relação jurídica material e da lesão causada em virtude da omissão das formas de expressão do Poder Estatal. Ora, existindo omissão do Estado, reconhece-se a lesão ao direito, pelo que, surgindo a pretensão do ofendido, nasce o direito de ação em face do Estado.

Impende a observação de que o Poder Judiciário não dispõe de competência constitucional para criar programas ou estabelecer a forma de execução dos atos legislativos e administrativos para a efetivação dos direitos fundamentais. Esta competência é constitucionalmente reservada ao Poder Legislativo e ao Poder Executivo.

Entretanto, nas hipóteses de insatisfação, a jurisdição é o veículo natural para a concessão do remédio jurídico necessário para a pacificação social. ${ }^{220} \mathrm{O}$ conflito existente entre os titulares do direito fundamental social e a conduta do Estado deve ser solucionado imperativamente pela jurisdição, mediante a "atuação da vontade concreta da lei". 221

Na hipótese aventada na Seção 5 do presente Capítulo, desde que comprovado que o bem da vida saúde não estava sendo espontaneamente satisfeito pelo Estado, nos termos do que dispõe o art. $11, \S 1^{\circ}$, do ECA, caberia ao Poder Judiciário condenar-lhe à

\footnotetext{
${ }^{218} \mathrm{Cf}$. CALAMANDREI, Piero. Instituciones de derecho procesal civil: segun el nuevo código. Trad. Santiago Sentís Melendo. Buenos Aires: Ediciones Juridicas Europa-America, 1973. v. 2, p. 19-21.

${ }^{219}$ Vide supra, Capítulo 2, Seção 5.

${ }^{220}$ DINAMARCO, Cândido Rangel. Instituições de direito processual civil, cit., v. 1, p. 299.

${ }^{221}$ CHIOVENDA, Giuseppe. Instituzioni di diritto processuale civile: i concetti fondamentali, la dottrina delle azioni. 2. ed. Napoli: Casa Editrice Dott. Eugenio Jovene, 1960. v. 1, p. 30-48.
} 
adequação dos estabelecimento de saúde, ou mesmo construir um estabelecimento, caso não exista no município. As políticas públicas necessárias para o atendimento do comando judicial seriam de inteira competência das demais formas de expressão do poder estatal, mediante a observância irrestrita do núcleo constitucional de irradiação previsto no art. 227 da Constituição Federal.

A partir de nossa proposição, e considerando-se a adoção, pelo Estado brasileiro, do princípio da inafastabilidade, ${ }^{222}$ consoante a dicção conferida ao art. $5^{\circ}$, inciso XXXV, da Constituição da República, todas as lesões a direitos fundamentais sociais levadas ao conhecimento do Poder Judiciário deverão ser obrigatoriamente apreciadas, desde que, é claro, sejam respeitados os mecanismos técnicos inerentes ao processo.

\subsection{Impossibilidade de invocação do princípio da separação de poderes para a não- -efetivação dos direitos fundamentais sociais}

Não é possível a invocação do princípio da separação dos poderes, para a não-apreciação da pretensão do titular do direito fundamental social. Como já ressaltado, o Poder Judiciário, durante o exercício do controle de constitucionalidade, não interfere na esfera exclusiva de atribuição das demais formas de expressão do poder estatal, porque atua exclusivamente no âmbito jurisdicional.

Por outro lado, o princípio da separação de poderes não pode ser utilizado para justificar a violação dos objetivos do Estado, aos quais todas as formas de expressão do poder estatal estão vinculadas. ${ }^{223}$

\footnotetext{
${ }^{222}$ Pontes DE MIRANDA, manifestando-se sobre o alcance político do princípio, afirmou que, em termos vulgares, "a última palavra tem-na a Justiça" (MIRANDA, Francisco Cavalcanti Pontes de. Comentários à Constituição de 1967, com a Emenda $n^{\circ}$ 1, de 1969. 2. ed. São Paulo: Ed. Revista dos Tribunais, 1974. t. 5 , p. 111).

${ }^{223}$ A dimensão política da jurisdição constitucional, identificada com o encargo de tornar efetivos os direitos fundamentais sociais, foi inicialmente assinalada no julgamento da ADPF 45/DF, Rel. Min. Celso de Mello, reconhecendo-se que a omissão do Poder Judiciário poderia resultar no comprometimento da integridade e da própria eficácia da Constituição. O mesmo entendimento foi reiterado, e adotado à unanimidade, pelo Supremo Tribunal Federal, no julgamento do RE 436.996-6 - Ag Rg, Rel. Min. Celso de Mello, julgamento em 22/11/05, DJ de 03/02/06, com a seguinte ementa: "RECURSO EXTRAORDINÁRIO - CRIANÇA DE ATÉ SEIS ANOS DE IDADE - ATENDIMENTO EM CRECHE E EM PRÉ-ESCOLA - EDUCAÇÃO INFANTIL - DIREITO ASSEGURADO PELO PRÓPRIO TEXTO CONSTITUCIONAL (CF, ART. 208, IV) - COMPREENSÃO GLOBAL DO DIREITO CONSTITUCIONAL À EDUCAÇÃO - DEVER JURÍDICO CUJA EXECUÇÃO SE IMPÕE AO PODER
} 
A atuação jurisdicional reflete, portanto, atividade corretiva do Estado-juiz, com o precípuo propósito de atender aos objetivos estatais, mediante a satisfação integral dos direitos fundamentais sociais, fator que assegura a unidade do sistema. De fato, como observa José Reinaldo de Lima Lopes, desde a República, ao Poder Judiciário foi reservado o papel de "árbitro possível dos grandes conflitos de poderes", carreando-lhe parte das atribuições do extinto Poder Moderador". 224

Os objetivos inscritos no art. $3^{\circ}$ da Constituição Federal constituem a materialização do compromisso ético assumido pelo Estado brasileiro na órbita internacional. Ora, se o Estado brasileiro adotou o sistema ético de referência, pautado na efetiva consecução dos direitos fundamentais, não pode o Poder Judiciário, como uma de suas formas de expressão, desviar-se deste compromisso político-institucional, recusando a atividade corretiva que a Constituição lhe outorgou.

Devemos lembrar, com Celso Lafer, que os direitos fundamentais trazem a ideia de domesticação do poder, subordinando-o à democracia. ${ }^{225}$

O equilíbrio de constitucionalidade, pois, é atingido quando o Poder Judiciário, em atividade residual e integradora, dá completude ao sistema, mediante a prolação de sentença, na qual vincula os agentes públicos à satisfação do bem da vida protegido pelo

PÚBLICO, NOTADAMENTE AO MUNICÍPIO (CF, ART. 211, § $2^{\circ}$ ) - RECURSO IMPROVIDO. - A educação infantil representa prerrogativa constitucional indisponível, que, deferida às crianças, a estas assegura, para efeito de seu desenvolvimento integral, e como primeira etapa do processo de educação básica, o atendimento em creche e o acesso à pré-escola (CF, art. 208, inciso IV). - Essa prerrogativa jurídica, em consequência, impõe, ao Estado, por efeito da alta significação social de que se reveste a educação infantil, a obrigação constitucional de criar condições objetivas que possibilitem, de maneira concreta, em favor das "crianças de zero a seis anos de idade" (CF, art. 208, IV), o efetivo acesso e atendimento em creches e unidades de pré-escola, sob pena de configurar-se inaceitável omissão governamental, apta a frustrar, injustamente, por inércia, o integral adimplemento, pelo Poder Público, de prestação estatal que lhe impôs o próprio texto da Constituição Federal. - A educação infantil, por qualificar-se como direito fundamental de toda criança, não se expõe, em seu processo de concretização, a avaliações meramente discricionárias da Administração Pública, nem se subordina a razões de puro pragmatismo governamental. - Os Municípios - que atuarão, prioritariamente, no ensino fundamental e na educação infantil $\left(\mathrm{CF}\right.$, art. $\left.211, \S 2^{\circ}\right)$ - não poderão demitir-se do mandato constitucional, juridicamente vinculante, que lhes foi outorgado pelo art. 208, IV, da Lei Fundamental da República, e que representa fator de limitação da discricionariedade político-administrativa dos entes municiapis, cujas opções, tratando-se do atendimento das crianças em creche (CF, art. 208, IV), não podem ser exercidas de modo a comprometer, com apoio em juízo de simples conveniência ou de mera oportunidade, a eficácia desse direito básico de índole social. - Embora resida, primariamente, nos Poderes Legislativo e Executivo, a prerrogativa de formular e executar políticas públicas, revela-se possível, no entanto, ao Poder Judiciário, determinar, ainda que em bases excepcionais, especialmente nas hipóteses de políticas públicas definidas pela própria Constituição, sejam estas implementadas pelos órgãos estatais inadimplentes, cuja omissão por importar em descumprimento dos encargos político-jurídicos que sobre eles incidem em caráter mandatório - mostra-se apta a comprometer a eficácia e a integridade de direitos sociais e culturais impregnados da estatura constitucional. A questão pertinente à "reserva do possível". Doutrina".

${ }^{224}$ LOPES, José Reinaldo de Lima. Direitos sociais: teoria e prática, cit., p. 30.

${ }^{225}$ LAFER, Celso. Globalização econômica, políticas neoliberais e os direitos econômicos, sociais e culturais. ENCONTRO BRASILEIRO DE DIREITOS HUMANOS, 1., cit., p. 47-51. 
direito fundamental social. Como não interfere arbitrariamente nos processos de escolha dos caminhos a serem percorridos até a consecução material do bem da vida, mas presta única e exclusivamente atividade jurisdicional, o Poder Judiciário mantém a independência das demais formas de expressão do poder estatal. E assim o faz em plena harmonia, porquanto simplesmente redireciona as políticas públicas, no limite do necessário para a consecução do princípio da igualdade substancial.

Há, in casu, a exata substituição da vontade das partes, pelo que se mantém o Poder Judiciário dentro de sua vocação natural: a jurisdição.

Válida, portanto, é a percepção de Alessando Pizzorno, segundo o qual, após a expansão da atuação do Poder Judiciário, este passou a exercer, durante o controle de constitucionalidade, o chamado "controle de correção política" ou "controle de virtude" dos atos dos demais poderes, o que, à evidência, causaria maior entrechoque com as demais formas de expressão do poder estatal. ${ }^{226}$

Neste ponto, deve-se ressaltar a magnitude do dever de imparcialidade dos órgãos jurisdicionais.

\subsection{A independência do Poder Judiciário e seus reflexos}

Como adverte Nicolò Trocker, a constitucionalização do direito de ação promoveu um alargamento da competência do Poder Judiciário, ${ }^{227}$ de forma que a imparcialidade dos magistrados passou a ser questionada. O receio de contaminação política dos juízes, ante o crescimento superlativo de seus poderes, tornou-se alvo de preocupação.

Todavia, trata-se somente de um alargamento de competência, através do qual os magistrados somam ao compromisso de aplicação e salvaguarda da lei o mesmo comprometimento em relação à Constituição. Desta forma, o único comprometimento dos magistrados é o político-institucional com a Constituição. Os magistrados, portanto, vinculam-se aos princípios fundamentais que orientaram o constituinte originário na

\footnotetext{
${ }^{226}$ PIZZORNO, Alessandro. Il potere dei giudici: Stato democratico e controllo della virtù. Roma: Laterza, 1998. p. 11-43.

${ }^{227}$ TROCKER, Nicolò. Processo civile e constituzione: problemi di diritto tedesco e italiano. Milano: Giuffrè, 1974. p. 710-712.
} 
elaboração da Constituição, em um exercício de soberania que lhes foi confiado pelo próprio Estado. ${ }^{228}$

É por tais motivos que se afirma que a independência dos juízes é garantida "ao grau máximo do ponto de vista político".229

Pierre Lepaulle afirma que a magistratura deve constituir um corpo organizado, não-sujeito a interferências do Poder Executivo e cujo dever é o de julgar da mesma forma todos os jurisdicionados. ${ }^{230}$ Mas, para que assim atue, o Poder Judiciário deve gozar de independência política e jurídica, de tal forma a não estar sujeito às injunções partidárias ou às pressões dos grupos de poder.

Com a assunção do controle de constitucionalidade pelo Poder Judiciário, as demais formas de expressão do poder estatal passaram a estar sob sua jurisdição. ${ }^{231}$ Este fenômeno tornou-se determinante na compreensão da independência do Poder Judiciário e do alcance da imparcialidade dos seus membros.

O art. 102 da Constituição Federal situa o Supremo Tribunal Federal como o órgão jurisdicional de superposição máxima, enquanto o seu art. $5^{\circ}$, inciso $\mathrm{XXXV}$, ao adotar o princípio da inafastabilidade, estabelece o critério lesão para o exercício do direito de ação, de forma a ampliar sobremaneira a competência do Poder Judiciário, o que inclui o exame de todos os atos inconstitucionais praticados pelas demais formas de expressão do poder estatal.

Diante deste contexto, o conceito de independência do Poder Judiciário alcança o plano de isenção completa em relação aos demais poderes, a fim de que seja preservado o princípio da igualdade. ${ }^{232}$ As contingências político-partidárias das demais formas de expressão do poder estatal não podem exercer qualquer grau de interferência, pois, na atividade jurisdicional. $^{233}$

${ }^{228}$ LA CHINA, Sergio. Manuale di diritto processuale civile: le disposizioni generali. Milano: Giuffrè, 2003. v. 1, p. 37-39.

${ }^{229}$ DENTI, Enrico; VELLANI, Mario. Diritto processuale civile: nozioni e rogole generali. 5. ed. Milano: Giuffrè, 2000. v. 1, p. 45-49.

${ }^{230}$ LEPAULLE, Pierre. La justice. Paris: Payot, 1934. p. 51-58.

${ }^{231}$ Afirma Salvatore Catinella que o controle de constitucionalidade exerceu influência no equilíbrio constitucional dos vários ramos de governo, com preponderância para o Poder Judiciário. Cf. CATINELlA, Salvatore. La Corte Suprema Federale nel sistema costituzionale degli Stati Uniti d'America. Padova: CEDAM, 1934. p. 11.

${ }^{232}$ REQUEJO PAGÉS, Juan Luis Requejo. Jurisdiccion e independencia judicial. Madrid: Centro de Estudios Constitucionales, 1989. p. 171. (Colección Estudios Constitucionales).

${ }^{233}$ Osvaldo Trigueira DO VALE traz passagem elucidativa das investidas arbitrárias contra a independência do Poder Judiciário: "Persuadiram-se os orientadores da Revolução, e o fato se repete em 1969 com o AI 
Esta especial característica da independência do Poder Judiciário é que originou a demanda por sua neutralização político-partidária.

André Pouille conclui que a natureza das finalidades do Poder Judiciário é idêntica à das demais formas de expressão do poder estatal. Mesmo assim, continua o autor, o Poder Judiciário deve ser independente, o que implica em completa separação e, por conseguinte, neutralização. ${ }^{234}$

A neutralização é a político-partidária e não a político-institucional. Como já assentado, os membros do Poder Judiciário têm um compromisso institucional com a opção política materializada, através da soberania popular, na Constituição Federal. ${ }^{235}$ Isto implica que a sua independência é diretamente proporcional ao nível de vinculação aos objetivos do Estado brasileiro.

Por consequência do que foi exposto, considera-se imparcial um Poder Judiciário que, não influenciado pelas vicissitudes político-partidárias, vincula-se completamente aos objetivos do Estado. Como um dos objetivos fundamentais do Estado é a efetivação da igualdade substancial, ex vi do disposto no art. $3^{\circ}$ da Constituição Federal, o Poder Judiciário demonstra toda a sua imparcialidade e independência ao efetivar, mediante prestação jurisdicional, os direitos fundamentais, em especial os sociais.

\subsection{A legitimidade democrática dos juízes para a efetivação dos direitos fundamentais sociais}

Como a igualdade substancial somente poderá ser atingida através da realização espontânea ou coercitiva dos direitos fundamentais sociais, a independência do Poder Judiciário e a imparcialidade de seus membros é condição necessária para a

n. ${ }^{\circ}$, que as decisões do Supremo oscilariam de acordo com o anterior vínculo político-partidário de seus membros (...) Esse fato não ocorreu (...) Aquela medida tinha a intenção de conquistar as decisões políticas do Supremo, independentemente do que restava do estado de direito, com a nomeação de ministros de militância partidária ortodoxamente udenista (...) A ótica de um Ministro do Supremo deverá ser, todavia, não apenas jurídica, o que seria uma atrofia, mas também político-social, e nunca dentro dos interesses restritos de casuísticas partidárias, nem nos esporádicos casos individuais, jamais no colegiado como instituição" (VALE, Osvaldo Trigueira do. O Supremo Tribunal Federal e a instabilidade políticoinstitucional. Rio de Janeiro: Civilização Brasileira, 1976. p. 1-5).

${ }^{234}$ POUILLE, André. Le pouvoir judiciaire et les tribunaux, cit., p. 15.

${ }^{235}$ Como afirma João Mendes de Almeida Júnior, "o poder judiciário não é mais do que uma emanação da soberania nacional e a jurisdicção é o poder conferido ao juiz para exercer suas funcções" (ALMEIDA JÚNIOR, João Mendes de. Programa do Curso Judiciário leccionado na Faculdade de Direito de S. Paulo. São Paulo: Typ. Hennies Irmãos, 1910. p. 11). 
afirmação da democracia social. ${ }^{236}$ Não é por outro motivo que a independência é garantia reivindicada e discutida nos diversos países que se pretendem democráticos. ${ }^{237}$

A imparcialidade dos órgãos jurisdicionais deve ser vista sob dois ângulos complementares. O primeiro, e mais tradicional, consiste na ausência de qualquer interesse na causa e o compromisso com a ordem jurídica e com sua consciência. Soma-se a este conceito de imparcialidade a vinculação do magistrado aos objetivos da Constituição e, em especial, a consecução dos direitos fundamentais.

Como já visto, a satisfação dos bens soberanos da humanidade, assegurados pelos direitos fundamentais, é objetivo que se alinha com o sistema ético de referência. ${ }^{238}$ Logo, juiz independente e imparcial é aquele que, no exercício de sua função, adota um sistema ético de referência, estabelecendo a pessoa humana como valor supremo, característica do Estado Democrático de Direito. ${ }^{239}$

A partir do momento em que todos os órgãos jurisdicionais adotarem um sistema ético de referência, o Poder Judiciário, como corpo organizado, atinge a plena independência preconizada na Constituição.

É por tais razões que não procede a assertiva de que os magistrados não detêm legitimidade democrática para determinar às demais formas de expressão do poder estatal a realização material dos bens da vida protegidos por direitos fundamentais sociais.

Afirma Carlos Ernst que a independência judicial é uma das "ferramentas necessárias para a garantia de um sistema democrático". ${ }^{240}$ De fato, se a democracia social pressupõe a igualdade substancial entre os membros da sociedade, a realização material desta igualdade não pode estar sujeita ao arbítrio das injunções político-partidárias. Estas injunções, que no campo da atuação legislativa e administrativa são, infelizmente, francamente acolhidas, diante da própria natureza das coisas, são inadmissíveis na atividade jurisdicional.

\footnotetext{
${ }^{236}$ REQUEJO PAGÉS, Juan Luis Requejo. Jurisdiccion e independencia judicial, cit., p. 171-177.

${ }^{237}$ Cf. SHETREET, Shimon; DESCHÊNES, Jules. Judicial Independence: the contemporary debate. Dordrecht: Martinus Nijhoff Publishers, 1985. 700 p.

${ }^{238}$ Vide supra, Capítulo 1, Seção 2.

${ }^{239}$ DALLARI, Dalmo de Abreu. Palestra proferida Rio de Janeiro, em novembro de 2001. In: ANAIS DO SEMINÁRIO O SUPREMO TRIBUNAL FEDERAL NA HISTÓRIA DA REPUBLICANA. Brasília, DF: AJUFE, 2002. p. 226-227.

${ }^{240}$ ERNST, Carlos. Independencia judicial y democracia. In: MALEM, Jorge; OROZCO, Jesús; VÁZQUEZ, Rodolfo (Coords.). La función judicial: ética y democracia. Barcelona: Gedisa, 2003. p. 235.
} 
Assim, não raro observamos a transferência vultosa de recursos do Estado para o atendimento de interesses político-partidários, com o objetivo de promover a manutenção dos agentes públicos no poder. Esta conduta é evidentemente arbitrária e foge completamente do sistema ético de referência do Estado. Além de antiética é inconstitucional. Caso não houvesse uma forma de expressão do poder estatal independente para a restauração ética do uso do poder, mediante o exercício do controle de constitucionalidade, estaríamos diante de uma forma de governo arbitrária, sem limites e desvinculada completamente do compromisso democrático.

Este é o motivo pelo qual se torna inadmissível um sistema de escolha de magistrados lastreado no escrutínio popular e por mandatos transitórios. O sistema de admissão por concurso público, mesmo que demande aperfeiçoamentos, anelado às garantais constitucionais conferidas aos magistrados (CF, art. 95), objetivam afastar completamente os magistrados das injunções político-partidárias. Enquanto o magistrado estiver preocupado com compromissos político-partidários ou com a transitoriedade de suas funções, haverá espaço fértil para o arbítrio e, portanto, para o desvio dos compromissos do Estado brasileiro.

Acertada, portanto, a escolha soberana do constituinte originário, ao garantir aos membros do Poder Judiciário as condições indispensáveis para o desenvolvimento desta necessária independência. Cabe aos magistrados, contudo, em unidade de propósitos, adotar, de forma irrestrita, o sistema ético de referência, a fim de que se estabeleça uma força conjunta, direcionada ao atendimento dos mais altos objetivos do Estado, com especial destaque para a efetivação dos direitos fundamentais sociais.

Desta forma, a única neutralização possível do Poder Judiciário reside na garantia de sua independência em relação às demais formas de expressão do poder estatal. Esta neutralização, por outro lado, somente será atingida quando todos os órgãos jurisdicionais executarem suas atividades com imparcialidade extrema, consistente na mais absoluta vinculação aos objetivos do Estado, em especial a realização plena dos direitos fundamentais.

Sob este aspecto, há forte tendência da doutrina, nos estudos sobre a democracia, de integrar o princípio da soberania à exigência de prioridade dos direitos fundamentais. Esta interdependência se reflete no papel preponderante dos direitos 
fundamentais para a construção da democracia. ${ }^{241}$ Daí a relevância do papel dos juízes na efetivação dos direitos fundamentais. ${ }^{242}$

Cabe, aqui, a advertência de Ronald Dworkin, de que o princípio democrático é, igualmente, limitador das decisões políticas dos magistrados. ${ }^{243}$ Desta forma, ao passo em que contribuem para a realização da democracia, os juízes estão igualmente limitados por ela.

Este é o contexto da plena legitimidade democrática de que gozam os magistrados no exercício da atividade jurisdicional. E quando atuam no sentido da realização dos direitos fundamentais sociais, os juízes não somente garantem a sua legitimidade democrática, como igualmente contribuem para a construção de uma democracia verdadeiramente social.

\subsection{Inadmissibilidade da invocação do tema "reserva do possível" durante a fase cognitiva do processo}

O âmbito da imparcialidade do magistrado se expande ao cotejarmo-lo com o princípio da inafastabilidade. Se toda e qualquer lesão, ou ameaça de lesão, a direito viabiliza o exercício do direito de ação ( $\mathrm{CF}$, art. $\left.5^{\circ}, \mathrm{XXXV}\right)$, não poderá o Poder Judiciário restringir o acesso das partes ao processo por fundamentos externos ao sistema do Direito Processual. $^{244}$

Um dos argumentos mais utilizados para justificar a ausência de efetividade dos direitos fundamentais sociais é o seu impacto econômico. A percepção de que a satisfação dos bens da vida protegidos pelos direitos fundamentais sociais causa vinculação

\footnotetext{
${ }^{241}$ POURTOIS, Hervé. Démocratie délibérative et droits fondamentaux. In: COUTU, Michel; BOSSET, P.; GENDREAU, C.; VILLENEUVE, D. (Dirs.). Droits fondamentaux et citoyenneté: une citoyenneté fragmentée, limitée, illusoire? Montréal: Thémis, 1999. p. 57-82.

${ }^{242}$ Inclusive, na França, afirma-se que os juízes participam do exercício da soberania nacional. Cf. RENOUX, Thierry. Le Conseil Constitutionnel et l'autorite judiciaire: l'élaboration d'ún droit constitutionnel juridictionnel, cit., p. 30-31.

${ }^{243}$ DWORKIN, Ronald. Une question de principe. Traduzido do inglês por Aurélie Guillain, A matter of principle. Paris: Presses Universitaires de France, 1996. p. 23-24.

${ }^{244}$ Interessante a observação de Eugenio Raúl ZAFFARONI sobre as estruturas judiciárias latino-americanas, reforçando a necessidade de um Poder Judiciário independente: "Em síntese, as estruturas judiciárias latinoamericanas são inadequadas para assumirem as demandas de uma democracia moderna, na medida em que a sua debilidade e dependência não lhes permitem desempenhar eficazmente a função delimitadora que requer a consolidação do espaço democrático (...)" (ZAFFARONI, Eugenio Raúl. Poder Judiciário: crise, acertos e desacertos, cit., p. 34).
} 
econômica no orçamento do Estado suscitou o tema da "reserva do possível", 245 amplamente difundido na doutrina e na jurisprudência, a ponto de ser utilizado como justificativa para eventual inércia do Poder Judiciário na tutela daqueles direitos. ${ }^{246}$

O equívoco desta concepção é o de não visualizar o real alcance da independência do Poder Judiciário. O compromisso dos magistrados não é com os programas partidários ou com as conveniências de determinados agentes públicos, por maior relevância que possam ter os seus cargos, e tampouco com as injunções de ordem orçamentária.

A Constituição, neste passo, não é neutra e nem postula a neutralidade do Estado. Ela apenas não se identifica com um particular projeto econômico, social, político ou ideológico e não permite que o Estado se identifique com ele. ${ }^{247}$

O Poder Judiciário tem compromisso exclusivo com a realização dos direitos fundamentais e, dada a amplitude de sua competência, decorrente da assunção do controle de constitucionalidade, o Estado é visualizado como devedor, e o orçamento como seu patrimônio. Se o patrimônio do Estado não é suficiente para o adimplemento completo de suas obrigações constitucionais, abre-se o caminho para a aplicação do princípio da proporcionalidade na utilização dos recursos.

Entretanto, o princípio da proporcionalidade será empregado na hipótese de execução provisória ou definitiva do título executivo judicial. O Poder Judiciário, desde que comprovada a lesão a direito fundamental social, deve projetar a mais ampla cognição da matéria, exarando, ao final, sentença, sobre a qual sobrevirá o trânsito em julgado. Durante o processo de conhecimento, portanto, não é dado ao Poder Judiciário absorver a questão econômica para paralisar sua atividade declaratória e condenatória. Isto representaria, em comparação com o plano privado, a esdrúxula figura na qual o devedor

\footnotetext{
${ }^{245}$ Cf. SUNSTEIN, Carl; HOLMES, Stephen. The cost of rights: why liberty depends on taxes. New York: Norton, 1999. $235 \mathrm{p}$.

${ }^{246}$ No RE no 436.996 - Ag Rg, já referido na nota de rodapé n ${ }^{\circ} 189$, o Min. Celso de Mello destacou a relevância do tema pertinente à "reserva do possível". Virgílio Afonso DA SILVA, após concluir que mesmo os deveres negativos do Estado, anelados aos direitos fundamentais de primeira geração, exigem um enorme gasto, assinala a necessidade de se acautelar com os excessos na concessão "desordenada, irracional e individualista" dos direitos sociais (SILVA, Luis Virgílio Afonso da. O Judiciário e as públicas: entre transformação social e obstáculo à realização dos direitos fundamentais. In: SOUZA NETO, Cláudio Pereira de; SARMENTO, Daniel (Coords.). Direitos sociais: fundamentos, judicialização e direitos sociais em espécie. Rio de Janeiro: Lumen Juris, 2008. p. 587-599).

${ }^{247}$ CANOTILHO, José Joaquim Gomes; MOREIRA, Vital. Constituição da República Portuguesa anotada, cit., v. 1, p. 9.
} 
não seria condenado à reparação do dano, porque não dispõe de patrimônio suficiente para o adimplemento futuro do título executivo judicial.

De outro vértice, o equilíbrio do orçamento, mediante o trato harmonioso entre a estruturação adequada do Sistema Tributário Nacional e o uso racional das finanças públicas, é tarefa exclusiva do Poder Legislativo e do Poder Executivo. Caso o Poder Judiciário absorva as injunções econômicas do orçamento como critério para a concessão dos direitos fundamentais, estará se desviando dos objetivos do Estado e, por via de consectário lógico, perdendo a sua independência constitucional.

Determinante, ainda, é a observação de Henry Shue, no sentido de que quaisquer direitos impõem deveres negativos e positivos, razão pela qual os direitos individuais igualmente demandam custos para o Estado. ${ }^{248}$ A prevalecer o pressuposto econômico, pois, não seria possível ao Poder Judiciário exercer efetiva proteção de quaisquer gerações de direitos fundamentais, ao receio de que o orçamento eventualmente não suportaria o impacto da prestação jurisdicional. ${ }^{249}$

O Poder Judiciário não tem aparato técnico para o exame contábil do orçamento público, tal como o instrumentalizado pelos Tribunais de Conta, em tarefa de apoio ao Poder Legislativo. E, dada a sua função eminentemente jurisdicional, não precisa adquirir tal aparato para o julgamento das demandas envolvendo os direitos fundamentais sociais. Isto porque o Poder Judiciário examina apenas a existência de lesão ao direito fundamental, decorrente da violação do dever constitucional do Estado de satisfazer aos bens da vida protegidos. Provada a violação, o órgão jurisdicional declara a existência do direito fundamental social e determina a sua irradiação material pelo Estado.

Quanto ao impacto orçamentário das decisões judiciais que ordenarem a satisfação dos direitos fundamentais subjetivos, cumprirá aos agentes públicos, no exercício das atividades legislativa e administrativa, promover o necessário rearranjo

\footnotetext{
${ }^{248}$ SHUE, Henry. Basic rights: subsistence, affluence and US foreign policy, Princeton: Princeton University Press, 1980. p. 37-38.

${ }^{249}$ Tal fato, entretanto, não afasta a realidade de que os direitos sociais naturalmente são mais custosos ao Estado, conforme a correta observação de Virgílio Afonso DA SILVA: “...boa parte dos requisitos fáticos, institucionais e legais para uma produção (quase) plena dos efeitos dos direitos civis e políticos já existe, enquanto que as reais condições para o exercício dos direitos sociais ainda têm que ser criadas. E a criação das condições de exercício dos direitos sociais é, pura e simplesmente, mais cara. Isto porque essas condições, além de incluírem tudo aquilo que é necessário para a produção de efeitos das liberdades públicas - proteção, organizações, procedimentos etc. - exigem algo a mais. E esse algo a mais, além de pressupor recursos financeiros não disponíveis, costuma ser específico para cada um dos direitos sociais, o que aumenta ainda mais os seus custos" (SILVA, Luis Virgílio Afonso da. O conteúdo essencial dos direitos fundamentais e a eficácia das normas constitucionais. Tese (Titularidade) - Faculdade de Direito, Universidade de São Paulo, São Paulo, 2005. p. 320).
} 
contábil para a respectiva harmonização financeira. ${ }^{250} \mathrm{E}$ tal se deve, pois a consequência do trânsito em julgado das sentenças será a vinculação irrestrita do orçamento à plena satisfação dos bens da vida garantidos pela atividade jurisdicional.

Este é, sem dúvida, o melhor alcance social que o Poder Judiciário poderia dar às suas decisões, na esteira do comando contido no art. $5^{\circ}$ da Lei de Introdução ao Código Civil, mui especialmente no caso de países subdesenvolvidos, em relação aos quais a opressão econômica e a miséria dos povos atingem patamares alarmantes. ${ }^{251}$ Ademais, a vinculação dos orçamentos às sentenças transitadas em julgado evitará que os agentes públicos possam manipulá-los arbitrariamente, destinando os escassos recursos públicos a interesses muitas vezes inconfessáveis.

Oportuna é a lembrança de que o Direito, como conceito orgânico da sociedade, abarca o fenômeno econômico, de tal forma que a economia política alcançou um caráter ético. Assim, o Direito não pode ser visualizado apenas em sua função de permitir a coexistência pacífica, mas também de regular as condições de desenvolvimento de todo o corpo social. ${ }^{252}$

Entrementes, conquanto o Poder Judiciário não esteja vinculado às injunções de ordem econômica e político-partidária, recomenda-se especial cautela, pelos magistrados, no exame das tutelas de urgência que envolvam a concessão de direitos fundamentais sociais. Deve existir um correto dimensionamento das tutelas de urgência, em matéria de direitos fundamentais sociais, na medida em que sua interferência no orçamento é imediata, o que pode gerar distúrbio nas demais atribuições do Estado, muitas vezes sem possibilidade de reversibilidade do provimento.

De toda a valia, por fim, a advertência de José Reinaldo de Lima Lopes, no sentido de que todo o cuidado deve ser reservado em relação ao provimento jurisdicional que conceda direitos fundamentais sociais, a fim de que o Poder Judiciário não assuma a

\footnotetext{
${ }^{250}$ José Casalta NABAIS ressalta que a ideia de direitos fundamentais está atrelada a deveres dos cidadãos, de tal forma que todos os membros da comunidade devem contribuir para o suporte financeiro dos direitos fundamentais. Trata-se de um binômio dever-direito. Cf. NABAIS, José Casalta. A face oculta dos direitos fundamentais: os deveres e os custos dos direitos. Revista de Direito Público da Economia, ano, 5, n. 20, p. 153-181, out./dez. 2007.

${ }^{251}$ Os Relatórios de Desenvolvimento Humano das Nações Unidas oferecem um panorama amplo para a análise dos diversos índices de desenvolvimento dos países do mundo todo. Cf. HUMAN Development Report. Disponível em: <http://hdr.undp.org/en/reports/research>.

${ }^{252}$ PUGLIA, Ferdinando. Il diritto nella vita economica. Messina: Carmelo de Stefano Ed., 1885. p. 56-57.
} 
"fila de atendimento" dos órgãos da Administração. É preciso, pois, segundo o autor, que o provimento jurisdicional permita o atendimento igualitário de todos os cidadãos. ${ }^{253}$

\subsection{O perigo da autoneutralização institucional do Poder Judiciário}

Através do exame do papel do Poder Judiciário na efetivação dos direitos fundamentais, notadamente os sociais, a percepção mais contundente é a de que o maior perigo para a realização destes direitos está na autoneutralização institucional dos magistrados.

Com efeito, dada a amplitude da jurisdição constitucional, o Poder Judiciário trouxe para o interior do processo as grandes questões nacionais. Como detentor da solução final dos conflitos, cabe exclusivamente ao Poder Judiciário aferir o âmbito de sua atuação. Destarte, a única forma de neutralização do Poder Judiciário, no Estado Democrático de Direito, é aquela estabelecida por seus próprios membros, mui especialmente os que exercem função jurisdicional nos órgãos de superposição.

É preciso que os magistrados tenham plena consciência do seu papel políticoinstitucional, não o confundindo com o dever de imparcialidade decorrente do afastamento das injunções político-partidárias.

João Mendes de Almeida Junior já afirmava, com toda razão, que o Poder Judiciário é um poder político, porque é uma “força derivada da soberania nacional”, razão pela qual foi constituído para garantir a inviolabilidade dos direitos. ${ }^{254}$ Esta garantia se estende, com muito mais razão, aos direitos fundamentais sociais.

Ao adotarem um sistema ético de referência, os órgãos jurisdicionais podem se concentrar na tarefa constitucional de realinhamento das políticas públicas, vinculando-as aos altos objetivos do Estado. Sem intromissão indevida na independência das demais formas de expressão do poder estatal, os magistrados determinam, em atividade corretiva e residual, a satisfação dos bens da vida necessários à consecução da igualdade substancial entre os cidadãos. Agindo com essa unidade, o Poder Judiciário contribui, conjuntamente

\footnotetext{
${ }^{253}$ LOPES, José Reinaldo de Lima. Em torno da "reserva do possível". In: SARLET, Ingo Wolfgang; TIMM, Luciano Benetti (Orgs.). Direitos fundamentais: orçamento e "reserva do possível”. Porto Alegre: Livraria do Advogado, 2008. p. 173-193.

${ }^{254}$ ALMEIDA JUNIOR, João Mendes de. Direito judiciario brazileiro. Rio de Janeiro: Typografia Baptista de Souza, 1918. p. 29-30.
} 
com as demais formas de expressão do poder estatal, para a afirmação da democracia social no país, impedindo o trânsito das forças arbitrárias no poder, tão nefastas à sobrevivência da humanidade.

A inserção da atividade jurisdicional na tarefa de afirmação democrática é missão histórica do Poder Judiciário, posto que a concretização dos direitos fundamentais demanda longa maturação social. ${ }^{255}$ Esta consciência deve ser continuamente enriquecida pelos tribunais.

A jurisdição, em última análise, objetiva a concretização do ordenamento jurídico em sua universalidade. ${ }^{256}$ A autoneutralização do Poder Judiciário, causando a incompletude do sistema, ante à inviabilização dos direitos fundamentais sociais, não atende, pois, ao desiderato de sua função constitucional. Muitas vezes é necessário que o Poder Judiciário ultrapasse a barreira normativista e atinja o âmago constitucional de sua finalidade. Não basta, portanto, interpretar as normas, mas é necessário integrá-las aos objetivos maiores do Estado.

Importantíssima é a observação do Ministro Enéas Galvão, ao afirmar que a Constituição "jamais deve ser interpretada no sentido de diminuir as condições de independência do Judiciário, que, neste regime, de algum modo, em certas circunstâncias, sobreleva os demais poderes". ${ }^{257}$ Ao se distanciar de sua gênese constitucional, o Poder Judiciário perde o referencial ético e se neutraliza, criando um sistema hermético, favorável à manipulação dos direitos fundamentais pelas demais formas de expressão do poder estatal.

É indispensável, pois, que o conflito seja absorvido e efetivamente resolvido Pelo Poder Judiciário. ${ }^{258}$ Não basta a simples absorção do conflito, mediante manifestação

\footnotetext{
${ }^{255}$ José de Melo ALEXANDRINO faz uma interessante estimativa sobre o tempo decorrido entre o primeiro texto constitucional e o momento a partir do qual os direitos fundamentais puderam ser considerados reconhecidos e garantidos em determinados países. O período seria, segundo o prestigiado autor, de até 100 anos no Canadá, na Suíça, na Alemanha e na Itália; entre 100 e 200 anos, no Brasil, em Portugal, na Espanha e nos EUA; mais de 200 anos, na França, por falta de tutela específica (ALEXANDRINO, José de Melo. Direitos fundamentais: introdução geral, cit., p. 14-18).

${ }^{256}$ MONTESANO, Luigi; ARIETA, Giovanni. Diritto processuale cvile: le disposizioni generali. 2. ed. Torino: G. Giappichelli, 1996. v. 1, p. 3-8.

${ }^{257}$ PRONUNCIAMENTO do Ministro Enéas Galvão. In: PACHECO, Felix. A Independência do Poder Judiciário e as prerrogativas do Supremo Tribunal Federal. Rio de Janeiro: Typ. do "Jornal do Commercio", de Rodrigues \& C., 1913. p. 47-51.

${ }^{258}$ BASTOS, Aurélio Wander Chaves. Conflitos sociais e limites do Poder Judiciário. Rio de Janeiro: Eldorado Tijuca, 1975. p. 114-157. Nem todos os conflitos sociais são absorvidos e decididos pelo Poder Judiciário: a velocidade de resposta, face à sua estrutura, é pequena. $\mathrm{O}$ autor utiliza uma visão sistêmica de entradas e saídas (demandas judiciais). Em muitos casos, o conflito social poderá ser absorvido, mas não será decidido.
} 
de que o Poder Judiciário não dispõe de condições institucionais para a efetivação dos direitos fundamentais sociais, argumento inequivocamente insubsistente. Deve o Poder Judiciário transformar o processo em fonte de bens da vida, estabelecendo a certeza jurídica, que não pode ser obtida por meios extraprocessuais. ${ }^{259}$

O paradigma normativista impede a adaptação do Poder Judiciário para os novos tempos, permitindo que as demais formas de expressão do poder estatal neutralizem alguns conflitos coletivos, sem resolvê-los de forma efetiva. ${ }^{260}$

Estes mecanismos de violação dos direitos fundamentais devem ser judicialmente bloqueados, sob pena de o próprio Poder Judiciário incidir em inconstitucionalidade, aferível a partir da fundamentação de suas decisões. ${ }^{261}$

Sem os direitos fundamentais, o Estado de Direito perde seu conteúdo, ${ }^{262}$ de forma que a autoneutralização do Poder Judiciário pode contribuir diretamente para tanto.

\subsection{Os desafios do Poder Judiciário no século XXI}

A atividade jurisdicional sofreu significativas transformações na transição do século XIX para o século XXI, ${ }^{263}$ em decorrência das várias posições políticas assumidas pelo Poder Judiciário ao longo de sua história. ${ }^{264}$

Nos albores da reconstrução do Estado francês, a necessidade de se limitar o poder arbitrário dos reis, bem como sua influência deletéria na atividade jurisdicional, a Constituição de 1791 construiu a estrutura do Poder Judiciário a partir do conceito de supremacia absoluta da lei. Desta forma, o Poder Judiciário transformou-se em um

\footnotetext{
${ }^{259}$ CHIOVENDA, Giuseppe. Instituzioni di diritto processuale civile: i concetti fondamentali, la dottrina delle azioni, cit., v. 1, p. 43-44.

${ }^{260}$ FARIA, José Eduardo. O Poder Judiciário no Brasil: paradoxos, desafios e alternativas. Brasília: Conselho da Justiça Federal, 1995. p. 37-85.

${ }^{261}$ ROCHA, José de Albuquerque. Estudos sobre o Poder Judiciário, cit., p. 67-70.

${ }^{262}$ LOPEZ PINA, Antonio. La garantia constitucional de los derechos fundamentales. Alemania, España, Francia e Italia. Madrid: Civitas, 1991. p. 19.

${ }^{263}$ Para um exame mais aprofundado desta transição, cf. BODIGUEL, Jean-Luc. Les magistrats: un corps sans ame? Paris: Puf, 1991.

${ }^{264}$ Sobre a história do Poder Judiciário no Brasil: NEQUETE, Lenine. O Poder Judiciário no Brasil: crônica dos tempos coloniais. Brasília: Supremo Tribunal Federal, 2000. v. 1 e v. 2.
} 
apêndice do Poder Legislativo, sem qualquer influência política nos destinos do Estado francês. ${ }^{265}$

Como consequência direta do pensamento liberal, os juízes passaram a se vincular totalmente à lei, restringindo sobremaneira a capacidade criativa do direito. Sem qualquer expressão política e tomando como parâmetro de comportamento único a lei, o Poder Judiciário naturalmente assumiu um papel meramente tecnocrático, ficando à margem das grandes decisões do Estado.

É natural, portanto, que as Constituições liberais não dessem grande relevância ao papel do Poder Judiciário, muitas vezes vinculando-o ao Poder Executivo. Evidentemente, tal estado de coisas iria comprometer a concepção de atividade judiciária, alinhando-a a dois parâmetros de atuação: a não-imiscuição de qualquer conteúdo político às decisões judiciais e a absoluta subordinação à atividade do Poder Legislativo.

A impossibilidade de agregar à atividade jurisdicional qualquer conteúdo político imunizou completamente a conduta dos agentes públicos vinculados ao Poder Legislativo e ao Poder Executivo, causando uma hipertrofia destes poderes, situação não-desejada por Montesquieu quando elaborou a teoria da separação de poderes.

No que tange à subordinação do Poder Judiciário à lei, a própria natureza das coisas comprovou que a multiplicidade de fatos e as suas derivações não permitiriam a sobrevivência de um sistema pretensamente completo e fechado. Aos poucos, a atividade criativa dos magistrados passou a ser uma constante, de forma que as construções jurisprudenciais adquiriram destacada relevância no mundo jurídico.

Entretanto, dois componentes extremamente importantes viriam a alterar completamente a posição política do Poder Judiciário e o âmbito de sua atuação.

O alargamento da competência do Poder Judiciário, iniciado nos Estados Unidos em 1803, causou um primeiro grande impacto no mundo jurídico. De mero subserviente da lei, o Poder Judiciário passou a ser o fiscal de sua correção. Agora o compromisso dos magistrados era com a Constituição e com a unidade do ordenamento jurídico.

Esta proeminência autoconferida pelo Poder Judiciário mostrou-se consentânea com os regimes democráticos, permitindo o controle satisfatório do poder. Desta forma,

\footnotetext{
${ }^{265}$ Sobre as instituições judiciárias na França, cf. RÉGOLI, Hervé. Institutions judiciaires. 2. ed. Paris: Dalloz, 1999. 233 p.
} 
gradualmente o Poder Judiciário erigiu-se em forma de expressão do poder estatal, igualando-se em relevância constitucional com o Poder Executivo e o Poder Legislativo.

Mas até então, o Poder Judiciário, por força das ideologias do Estado liberal, embora reconhecesse a proeminência de sua jurisdição constitucional, ainda estava arraigado ao seu compromisso com sua atividade intrinsecamente passiva. Assim é que a violação aos direitos fundamentais pelas demais formas de expressão do poder estatal era reprimida através da subtração da validade e dos efeitos dos atos dos seus agentes públicos. Em outras palavras, o Poder Judiciário habituou-se a corrigir os atos comissivos dos agentes públicos, violadores dos direitos fundamentais de primeira geração.

Ocorre que uma nova geração de direitos estava sendo paulatinamente engendrada e foi finalmente institucionalizada, pela primeira vez, na Constituição alemã de Weimar, em 1919. Após as deletérias consequências da Primeira Guerra Mundial (19141918), novos direitos foram acrescentados à norma fundamental alemã, relativos ao trabalho, à educação, à cultura e à previdência. O Estado, pois, estava reorganizado em função da sociedade e não mais em função do indivíduo. Iniciava-se o Estado social.

Desde 1919, o Poder Judiciário passou a enfrentar uma realidade completamente diferente. Não só a conduta ativa dos agentes públicos violava direitos constitucionalmente assegurados, mas também a conduta passiva do Estado. Reconhecia-se a existência dos direitos fundamentais de segunda geração, mas compreendia-se que a sua realização demandava, obrigatoriamente, a atuação espontânea dos agentes públicos. Esta atuação, vertida para as Constituições, recebeu a designação de normas programáticas.

Ao descaso com os direitos fundamentais sociais, e à contínua autoneutralização do Poder Judiciário, muito influenciada pelo positivismo-normativista, sobreveio a Segunda Guerra Mundial, em 1939. Com o término da guerra, em 1945, e diante do mais completo aniquilamento da dignidade humana jamais assistido, as nações do mundo se reuniram para declarar, em 1948, que o homem era o centro de irradiação de todos os valores. Declarou-se, na oportunidade, que a dignidade humana era o bem maior da humanidade, o seu bem soberano. Iniciou-se, então, uma renovação ética do Direito com a assinatura e a divulgação da Declaração Universal dos Direitos Humanos.

O mundo adotou um novo sistema ético de referência, baseado na luta intransigente pela defesa dos direitos humanos. Tal concepção, pelo compromisso assumido pelos Estados, cuja soberania foi voluntariamente relativizada diante do sistema 
internacional de proteção dos direitos humanos, passou a ser institucionalizada nas diversas Constituições.

Durante a transição do Estado liberal para o Estado social, surgiram basicamente três tipologias constitucionais da Administração da Justiça no mundo: o constitucionalismo autocrático, o constitucionalismo democrático europeu e o constitucionalismo democrático americano. ${ }^{266}$ Mas três perfis da magistratura podem ser destacados.

A Inglaterra, país de antiga tradição constitucional, influenciou os regimes modernos. Embora tenha produzido alguns documentos decisivos, a Inglaterra não possui constituição escrita, mas confere grande amplitude à jurisdição. O sistema adotado é o da common law, constituindo a equity fonte do direito. Prevalece o critério do case system e do stare decision. Não há, na Inglaterra, Ministro da Justiça, e a magistratura não constitui, propriamente, uma carreira tipicamente profissional. A separação dos poderes influenciou, sobretudo, a formação do Parlamento. ${ }^{267}$

\footnotetext{
${ }^{266}$ DROMI, Roberto. El Poder Judicial. Buenos Aires: Ediciones Ciudad Argentina, 1996. p. 11-31. De forma sintética, as tipologias podem ser assim explicadas: a) Constitucionalismo autocrático: Estados "autoritários", "totalitários", "monocráticos" ou nas chamadas "democracias marxistas" - a função judicial se organiza na forma de tribunais e não é considerado poder do Estado. Declara-se expressamente a "dependência hierárquica" da "Assembléia Nacional" ou do "Soviet Supremo" e proclama-se sua "independência funcional de outros órgãos". Os juízes estão submetidos somente à lei, mas são dependentes do regime. São exemplos: Constituição da URSS, de 1977, art. 151, 153 e 155; Constituição da República Popular da Polônia, de 1952, arts. 57, 58, 60 e 62; Constituição da República de Cuba, de 1976, arts. 121, 122, 123, 125 e 128; Constituição da República Socialista da Albânia, de 1976, arts. 65 e 105; Constituição da República Democrática da Alemanha, de 1968, revisada em 1974, arts. 92 e 96; Constituição da República Popular da Bulgária, de 1971, art. 125; Constituição da República Socialista da Checoslováquia, de 1968, art. 97 e ss; Constituição da República Socialista da Romênia, de 1974, arts. 42, 101 e 102; Constituição da República Socialista Federativa da Iugoslávia, de 1974, arts. 282 e 369. b) Constitucionalismo democrático europeu: forma monárquica ou republicana - organização administrativa hierarquizada - independência funcional de outros órgãos do Estado - não investe a hierarquia de poder político-institucional - a jurisdição não é "terceiro poder do Estado", governo - o Poder Judiciário não exerce o controle de constitucionalidade. Ex.: Lei Fundamental da República Federal Alemã, de 1949, arts. 92, 95 e 97; Constituição da Irlanda, de 1937, arts. 34 e 35; Constituição da República da Islândia, de 1944, arts. 2, 59 e 60; Constituição da Bélgica, de 1831, art. 30 e 100; Constituição da República Italiana, de 1947, art. 104; Constituição da Espanha, de 1978, arts. 97, 117 a 127; Constituição da República Francesa, de 1958, arts. 20, 56, 64 a 68; Instrumento de Governo da Suécia, de 1974, Cap. I, arts. 3 e 7, e Cap. XI, art. $1^{\text {o}}$; Constituição Federal da Confederação Suíça, de 1879, arts. 71 e 106. Exceção: Constituição da República de Portugal, de 1976, que no seu art. 113 reconhece o Poder Judiciário como poder do Estado e faculta-lhe o controle de constitucionalidade, não obstante a competência da "Comissão Constitucional", art. 283. c) Constitucionalismo democrático americano: o Poder Judiciário é poder político - é poder do Estado - está "investido de poder político-constitucional" - A jurisdição se apresenta como a categoria de poder que, como poder moderador e tribunal das garantias constitucionais, "integra o governo". Constituição dos EUA.

${ }^{267}$ RUINI, Meuccio. La nostra e le cento costituzioni del mondo: problemi aperti: Organi Costituzionali. Milano: Giuffrè, 1964. p. 791-793.
} 
Os Estados Unidos por outro lado, conferem ampla jurisdição ao Poder Judiciário e maior alcance à equity, comparativamente à Inglaterra. A magistratura exercita o controle sobre os atos administrativos. A característica marcante deste perfil da magistratura é o amplíssimo controle de constitucionalidade, com acentuada separação dos poderes. $^{268}$

A França exerceu grande influência no continente europeu ${ }^{269}$ e na América Latina. A abrangência da jurisdição é bem limitada em relação aos países anglo-saxões, existindo pouco espaço para a equidade e para o costume, de forma que o direito escrito detém máxima eficácia. O Poder Judiciário, entretanto, não tem ingerência no controle de constitucionalidade. O princípio da separação de poderes, na França, é muito mais nítido do que na Inglaterra. Embora a inamovibilidade dos juízes seja reconhecida desde o Velho Regime, o Presidente da República tem efetiva influência no campo da magistratura, sendo considerado o "garante da independência" das autoridades judiciárias. ${ }^{270}$

No Brasil, após anos de arbítrio e concluída a transição democrática iniciada em 1985, o Poder Judiciário brasileiro viu-se diante da Constituição de $1988 .{ }^{271}$ Um modelo de Estado social foi adotado, ao passo em que as várias gerações de direitos fundamentais foram institucionalizadas. Plexos de normas programáticas foram inseridos no bojo da Constituição, sinalizando o intento do legislador constituinte de promover a efetivação dos direitos fundamentais de segunda e de terceira geração. Por fim, manteve a Constituição brasileira o sistema de controle judicial de constitucionalidade, ampliando sobremaneira a competência do Poder Judiciário, em especial a do Supremo Tribunal Federal, como órgão de superposição máxima.

O Estado brasileiro adotou, portanto, o constitucionalismo democrático americano como a sua tipologia de Administração da Justiça, inserindo o Poder Judiciário entre as formas de expressão do poder estatal. Contudo, segue o sistema romanogermânico, tal como a França, situação que gera contínua necessidade de adaptação do sistema.

\footnotetext{
${ }^{268}$ RUINI, Meuccio. La nostra e le cento costituzioni del mondo: problemi aperti: Organi Costituzionali, cit., p. 794-795.

${ }^{269}$ Atualmente, como lembra Alec Stone SWEET, a Corte Européia de Justiça "não tem rival como o mais efetivo corpo judicial supranacional na história do mundo, comparada favoravelmente com as mais poderosas cortes constitucionais de qualquer lugar" (SWEET, Alec Stone. The judicial construction of Europe. New York: Oxford, 2004. p. 1-44).

${ }^{270}$ RUINI, Meuccio. La nostra e le cento costituzioni del mondo: problemi aperti: Organi Costituzionali, cit., p. 796-798.

${ }^{271}$ Para um estudo mais completo da história do Poder Judiciário brasileiro, cf. NEQUETE, Lenine. O Poder Judiciário no Brasil: crônica dos tempos coloniais, cit.
} 
Mais de duas décadas após a promulgação da Constituição de 1988, o Poder Judiciário brasileiro ainda procura dimensionar o exato alcance de suas atribuições constitucionais, face à extrema complexidade dos sistemas já delineados. Daí porque podem ser apontados cinco grandes desafios a serem vencidos pelo Poder Judiciário brasileiro.

A primeira questão posta é a da superlativa competência carreada ao Poder Judiciário, decorrente do sistema de controle de constitucionalidade e que transforma em jurisdicionados todos os agentes políticos, inclusive os entes públicos. ${ }^{272}$ É indiscutível, em face desta realidade, que o Poder Judiciário é um poder político, decorrente da soberania do Estado, e, pelas suas peculiaridades, deve ser concebido como uma "instituição criada e existente fora do mesmo Estado". ${ }^{273}$ Entretanto, o exercício da jurisdição deve traduzir juridicamente este poder político. ${ }^{274}$ As questões político-institucionais, portanto, devem ser trazidas ao processo, mas encaradas sob o enfoque exclusivamente jurídico-normativo.

Esta forma de abordagem da jurisdição somente poderá ser implementada se o Poder Judiciário se mantiver estritamente independente das demais formas de expressão do poder estatal. Todavia, para que o próprio Poder Judiciário mantenha esta independência, é necessário que adote o mesmo sistema ético de referência do Estado brasileiro, centrado na realização dos direitos fundamentais e na afirmação democrática do poder.

É neste sentido que podemos afirmar, com Gérard Conac, que o Poder Judiciário é uma instituição "chamada a assumir uma função ética”, embora a sua atividade primordial seja a de declarar o direito no caso concreto. ${ }^{275}$

Coloca-se, então, o segundo desafio do Poder Judiciário, porquanto a realização dos direitos fundamentais não poderá ensejar a invasão da esfera de

\footnotetext{
${ }^{272}$ Como recorda Niceto Alcalá-Zamora y CASTILLO, para que o processo atenda a seus objetivos, o poder de coação do terceiro imparcial deve ser tal que permita o cumprimento de sua decisão. Desta forma, o terceiro imparcial deve ser "mais forte que as partes" (ALCALÁ-ZAMORA Y CASTILLO, Niceto. Proceso, autocomposición y autodefensa. 2. ed. México: UNAM, 1970. p. 12-14).

${ }^{273}$ LESSA, Pedro. Do Poder Judiciário. Ed. fac-similar. Brasília: Senado Federal, Conselho Editorial, 2003. p. 5-4. (Coleção História constitucional brasileira).

${ }^{274}$ Segundo Castro Nunes, o conceito de jurisdição não se confina aos estreitos limites do "direito judiciário". Domina praticamente toda a atividade do Estado moderno, pouco importando o órgão que o exerça (impeachment, por exemplo), de forma que as vias judiciais não esgotam toda a jurisdição do Estado. Por fim, destaca que o Estado cada vez mais se define pela "jurisdicionalização", consistente na sujeição de todos à lei geral. Cf. NUNES, José de Castro. Teoria e prática do Poder Judiciário. Rio de Janeiro: Revista Forense, 1943. p. 3.

${ }^{275}$ CONAC, Gérard. Justice et Constitutions, cit., p. 16-17.
} 
competência constitucional das demais formas de expressão do poder estatal. ${ }^{276}$ Desta forma, é imprescindível que os magistrados atuem nos exatos termos da jurisdição, ou seja, com o objetivo de fazer atuar a vontade concreta do ordenamento jurídico. As políticas públicas, representadas pelos atos legislativos e administrativos, não poderão ser arbitrariamente substituídas pela jurisdição. Todavia, estas mesmas políticas públicas deverão ser realinhadas pela atividade jurisdicional.

O terceiro desafio do Poder Judiciário será atingir a transição de pensamento necessária para não assumir uma posição meramente contemplativa em relação às omissões do Estado na satisfação dos direitos fundamentais sociais. Segue-se que, adotando o sistema ético de referência do Estado, traduzido no art. $3^{\circ}$ da Constituição Federal, a prestação jurisdicional deverá ser pró-ativa, mediante a concessão dos bens da vida protegidos pelos direitos fundamentais, com absoluta independência e imparcialidade. Daí o necessário afastamento dos magistrados das injunções político-partidárias e econômicas. O Poder Judiciário, portanto, deverá assumir uma postura que evite a sua autoneutralização.

O Poder Judiciário, contudo, é um corpo organizado, composto por uma estrutura complexa e ramificada em inúmeros órgãos, monocráticos e singulares. $\mathrm{O}$ seu quarto desafio será, então, a propagação do sistema ético de referência a todos os órgãos jurisdicionais, de modo a integrá-los perfeitamente às suas funções constitucionais. Esta tarefa deverá ser desenvolvida desde a captação de juízes, até a instrumentalização dos meios que permitam o contínuo aprimoramento cultural multidisciplinar dos seus membros, necessária para a compreensão da complexidade do mundo contemporâneo. ${ }^{277} \mathrm{O}$ objetivo é manutenção da unidade do sistema. ${ }^{278}$

O último e quinto desafio será o de desenvolver uma técnica de decisão, ${ }^{279}$ que traga para o processo todas as novas atribuições constitucionais do Poder Judiciário, sem

\footnotetext{
${ }^{276}$ Utilizamos a expressão "esfera de competência constitucional”, pois, enquanto a teoria da separação dos poderes tem sofridos inúmeros rearranjos para a acomodação das diversas orientações políticas relativas às funções do Estado. Cf. SALAZAR, Alcino. Poder Judiciário. Rio de Janeiro: Forense, 1975. p. 32-35.

${ }^{277}$ Cf. FARIA, José Eduardo. Introdução: o Judiciário e o desenvolvimento sócio-econômico. In:

(Org.). Direitos humanos, direitos sociais e justiça. São Paulo: Malheiros Ed., 2005. p. 26 e s.

${ }^{278}$ Segundo G. LEONE, a disciplina constitucional do Poder Judiciário "deve, acima de tudo, obedecer a um critério de concentração sintética apta a imprimir à norma que será emanada aquela unidade de caráter sistemático que deve informar toda Carta constitucional" (LEONE, G. Potere Giudiziario e Corte di Garanzia Costituzionale. Appendici - I Projetti di Riforma. In: RIGANO, Francesco. Costituzione e Potere Giudiziario: ricerca sulla formazione delle norme costituzionali, cit., p. 273).

${ }^{279}$ A técnica de decisão, entretanto, deve estar desvestida de qualquer conteúdo burocrático. Como recorda Ralf DAHRENDORF, embora a burocracia seja comum no mundo contemporâneo, ela conflita com os direitos humanos (DAHRENDORF, Ralf. O conflito social moderno: um ensaio sobre a política da liberdade. Tradução de Renato Aguiar e Marco Antonio Esteves da Rocha. Rio de Janeiro; São Paulo: Jorge Zahar; EDUSP, 1992. p. 173-199).
} 
causar impacto nos últimos quatro desafios propostos. A atividade jurisdicional deverá atingir um patamar técnico-jurídico tal, que traduza juridicamente as questões políticoinstitucionais, preserve o princípio da separação de poderes, promova a completa efetivação dos direitos fundamentais sociais e mantenha a unidade do sistema. 


\section{CAPÍtUlo III. ÂMBITO DE COGNIÇÃo DAS POLÍticAS PÚBLICAS NO PROCESSO COLETIVO}

\section{Crise metodológica e desconsideração dos direitos fundamentais sociais como objeto de tutela no processo coletivo}

O processo coletivo é o instrumento de excelência no campo da proteção jurídica dos interesses e dos direitos metaindividuais. Trata-se de um conceito altamente abstrato, que pressupõe, e fundamenta, a possibilidade de tutela jurisdicional de direitos pertencentes a um grupo determinado ou indeterminado de pessoas, em uma mesma relação jurídica processual. ${ }^{280}$ Mesmo que a ciência processual já convivesse com a ideia clássica das relações plurissubjetivas, ${ }^{281}$ a possibilidade de indeterminação das partes e do estabelecimento de uma adequada representação, no processo coletivo, promoveu a ruptura de todo o arcabouço processual, alterando profundamente os seus principais institutos. ${ }^{282}$

Entretanto, o processo coletivo, conquanto tenha atingido elevada maturidade científica, a ponto de caminharmos, no atual "estado da arte", para um Código Brasileiro de Processos Coletivos, para uma teoria geral ${ }^{283}$ e para um Código Modelo de Processos Coletivos para Ibero-américa, ${ }^{284}$ não tem sido utilizado para dar vazão ao que deveria ser um dos seus principais objetivos: a efetivação dos direitos fundamentais sociais.

\footnotetext{
${ }^{280}$ José Carlos Barbosa MOREIRA aponta três "pontos sensíveis" da problemática decorrente do estudo dos interesses coletivos ou difusos: a legitimidade ativa para a causa, o tipo da tutela a ser proporcionada pelo órgão jurisdicional e os efeitos do julgamento e da coisa julgada (MOREIRA, José Carlos Barbosa. A proteção jurisdicional dos interesses coletivos ou difusos. In: GRINOVER, Ada Pellegrini (Coord.). A tutela dos interesses difusos. São Paulo: Max Limonad, 1984. p. 98-106).

${ }^{281}$ WATANABE, Kazuo. Tutela jurisdicional dos interesses difusos: a legitimação para agir. In: GRINOVER, Ada Pellegrini (Coord.). A tutela dos interesses difusos, cit., p. 87.

${ }^{282}$ Mauro CAPPELLETTI chegou a afirmar que estava em curso uma verdadeira revolução no Direito Processual Civil (CAPPELLETTI, Mauro. Formações sociais e interesses coletivos diante da justiça civil. São Paulo. Separata da Revista de Processo, São Paulo, n. 105, p. 128-159, 1977).

${ }^{283}$ GRINOVER, Ada Pellegrini. Direito processual coletivo. In: GRINOVER, Ada Pellegrini; MENDES, Aluisio Gonçalves de Castro; WATANABE, Kazuo (Coords.). Direito processual coletivo e o anteprojeto de Código Brasileiro de Processos Coletivos. São Paulo: Ed. Revista dos Tribunais, 2007, p. 11 e s).

${ }^{284}$ Cf. GRINOVER, Ada Pellegrini. Relatório Geral - Civil Law: os processos coletivos nos países de civil law. In: GRINOVER, Ada Pellegrini; WATANABE, Kazuo; MULLENIX, Linda. Os processos coletivos nos países de civil law e common law: uma análise de direito comparado. São Paulo: Ed. Revista dos Tribunais, 2008. p. 24 e s.
} 
Trata-se de crise metodológica decorrente da desconexão entre o direito constitucional e o direito processual. Em verdade, esta desconexão se deve muito mais à pouca importância que se tem dispensado à efetivação dos direitos fundamentais sociais e à tergiversação acerca da determinação do âmbito de atuação do Poder Judiciário no Brasil. $^{285}$ Estes dois elementos acabaram restringindo o alcance da jurisdição, instituto fundamental da ciência processual.

Com efeito, a partir de 1919, os chamados direitos sociais foram inseridos, pela primeira vez, no bojo de uma Constituição, a Constituição de Weimar. Ocorre que, apesar deste enorme avanço na concepção do Estado, a ciência do direito processual nascia em 1868, com a publicação, na Alemanha, da obra de Oscar Von Bülow, Teoria das Exceções e dos Pressupostos Processuais, na qual se descortinavam os primeiros contornos da relação jurídica processual. ${ }^{286}$

Embora Emilio Bonaudi já apontasse, em 1911, a relevância da tutela dos interesses coletivos, ante o rápido desenvolvimento da economia moderna, a crescente atividade comercial e o aperfeiçoamento da grande indústria, ${ }^{287}$ a discussão mais séria sobre os direitos coletivos somente seria encetada na década de 70, no Congresso de Pavia de $1974 .^{288}$

Longo tempo decorreria no Brasil até que fossem assentados os fundamentos do direito processual constitucional, método que permitiu a análise do processo em suas relações com a Constituição. ${ }^{289}$ Até então, o direito processual ainda estava muito

\footnotetext{
${ }^{285}$ Assinala Ada Pellegrini GRINOVER que a moderna processualística busca conciliar o método técnicocientífico com as preocupações sócio-políticas, de forma a empregar "escrupulosamente a técnica processual para atingir os diversos escopos da jurisdição" (GRINOVER, Ada Pellegrini. O magistério de Enrico Tullio Liebman no Brasil. Revista da Associação dos Juízes do Rio Grande do Sul, Porto Alegre, ano 14 , p. 80-83, 1987). Neste sentido é que se busca estabelecer a exata dimensão da atividade jurisdicional na tarefa estatal de efetivação dos direitos fundamentais sociais.

${ }^{286}$ DINAMARCO, Cândido Rangel. Fundamentos do processo civil moderno. 2. ed. São Paulo: Ed. Revista dos Tribunais, 1987. p. 12.

${ }^{287}$ BONAUDI, Emilio. La tutela degli interessi collettivi. Milano: Fratelli Bocca, 1911. p. 5.

${ }^{288}$ GRINOVER, Ada Pellegrini. A defesa do meio ambiente em juízo como conquista da cidadania. $C E J$ Revista de Estudos do Conselho da Justiça Federal, Brasília, n. 9, p. 96, set./dez. 1999.

${ }^{289}$ CINTRA, Antonio Carlos de Araújo; DINAMARCO, Cândido Rangel; GRINOVER, Ada Pellegrini. Teoria geral do processo. 8. ed. São Paulo: Ed. Revista dos Tribunais, 1991. p. 76. Nesta mesma perspectiva, Ada Pellegrini GRINOVER afirma que a ligação existente entre constituição e processo promoveu uma leitura dos institutos processuais segundo um sistema unitário do ordenamento jurídico, erigindo o processo à garantia de liberdade (GRINOVER, Ada Pellegrini. Os princípios constitucionais e o Código de Processo Civil. São Paulo: Bushatsky, 1975. p. 3-4). De qualquer forma, como ressalta Ada Pellegrini GRINOVER, o Brasil foi o primeiro país a introduzir, em Ibero-América, "a tutela dos interesses difusos e coletivos, de natureza indivisível, antes de tudo pela reforma de 1965 da lei da ação popular" (GRINOVER, Ada Pellegrini. Ações coletivas ibero-americanas: novas questões sobre a legitimação e a coisa julgada. Revista Forense, Rio de Janeiro, v. 361, p. 3, maio/jun. 2002).
} 
arraigado aos pressupostos individualistas característicos do Estado liberal, cujas implicações redutoras no conceito de jurisdição somente foram vencidas a partir do instrumentalismo, ${ }^{290}$ teoria que definiu os escopos jurídico, social e político da jurisdição e representou um importante passo na evolução da ciência processual. ${ }^{291}$

Mas a jurisdição, como categoria jurídica da ciência processual, ainda sofre fortíssimas influências do direito constitucional, em especial no que tange ao exato alcance do princípio da separação de poderes, expressamente consignado no art. $2^{\circ}$ da Constituição Federal. A indeterminação do princípio tem sido uma das causas preponderantes para a perplexidade da ciência processual nas hipóteses, gravíssimas e constantes, de violação dos direitos fundamentais sociais, em face da inércia dos poderes Legislativo e Executivo.

Aspecto relevante para a indeterminação do exato alcance da separação dos poderes é a hibridez do sistema jurídico brasileiro. Ao tempo em que o Estado brasileiro se alinhou ao ramo do direito romano-germânico, adotou o sistema judicial de controle de constitucionalidade utilizado nos Estados Unidos, do ramo da common law. Assim é que se exercita no Brasil um controle de constitucionalidade amplíssimo como o americano, que confere ao Poder Judiciário o status de poder político, ao mesmo tempo em que o direito é aplicado tradicionalmente segundo as regras da civil law, com a destacada proeminência da lei e a característica supressão dos poderes dos juízes, herança do direito francês. ${ }^{292}$

Paulatinamente, a doutrina e a jurisprudência foram vencendo resistências, de tal forma que, atualmente, o Poder Judiciário brasileiro já reconhece sua jurisdição sobre as demais formas de expressão do poder estatal. As tradicionais "questões políticas" já se encontram em boa parte superadas, bem como a possibilidade de invasão, pelo Poder Judiciário, do mérito do ato administrativo, ex vi do disposto no art. 37, caput, da Constituição da República.

Entretanto, grande é a divergência doutrinária e jurisprudencial sobre a possibilidade de controle das políticas públicas através do Poder Judiciário. O controle dos

\footnotetext{
${ }^{290}$ Sobre a instrumentalidade que se atribui ao processo, especialmente no que tange aos escopos da jurisdição, cf., por todos, DINAMARCO, Cândido Rangel. A instrumentalidade do processo. 8. ed. São Paulo: Malheiros Ed., 2000. p. 149 e s.

${ }^{291}$ Sobre a evolução do direito processual civil no Brasil, cf., por todos, GRINOVER, Ada Pellegrini. Modernidade do direito processual brasileiro. In: ___ O processo em evolução. Rio de Janeiro: Forense, 1996. p. 6-14. Ainda, da mesma autora, Deformalização do processo e deformalização ds controvérsias. Revista de Processo, São Paulo, ano 12, n. 46, p. 60-61, abr./jun. 1987.

${ }^{292}$ Esta mesma característica do direito brasileiro foi destacada por Enrico Tullio LIEBMAN. Cf. Diritto comune e processo civile brasiliano. In: STUDI in onore di Enrico Redenti nel XL anno del suo insegnamento. Milano: Giuffrè, 1951. v. 1, p. 581-583.
} 
atos comissivos do Estado, representados por políticas públicas ilegais ou inconstitucionais, não oferece maiores entraves. É a omissão do Estado na realização das políticas públicas que está a causar um impasse na compreensão do alcance do processo de interesse coletivo. $^{293}$

Em uma primeira análise, cotejados os tradicionais conceitos de jurisdição ${ }^{294} \mathrm{e}$ a estrutura das ações coletivas brasileiras, em especial a ação civil pública, concluir-se-ia que o sistema não permitiria tal controle, ante o princípio da tripartição dos poderes, inscrito no art. $2^{\circ}$ da Constituição Federal. Ademais, desde que admitido, o controle de políticas públicas através do processo coletivo esbarraria no problema do cumprimento da sentença. Em caso do estabelecimento de obrigação de fazer (LACP, art. $2^{\circ}$ ), ante a omissão do Poder Público, fatalmente o Poder Judiciário teria que ingressar, pormenorizadamente, na atividade discricionária da Administração, a ponto de, exemplificativamente, avaliar a melhor forma de construção de uma escola (extinção da obrigação).

O estudo mais aprofundado da questão, em confronto com o comportamento dos tribunais brasileiros, revelou, contudo, que o objeto das ações coletivas encontra-se inadmissivelmente restringido. Tal restrição decorre do trato divorciado entre o processo coletivo e o reconhecimento, em nível internacional, dos direitos que também lhe deram origem, tanto assim considerados os direitos fundamentais de segunda geração.

A doutrina defende a ampliação do objeto da ação civil pública, ${ }^{295}$ sustentando a intervenção do Poder Judiciário para o controle de políticas públicas. Lastreados na evolução do instituto, os doutrinadores pretendem ampliar o objeto da ação civil pública a

\footnotetext{
${ }^{293}$ WATANABE, Kazuo. Processo civil de interesse público: introdução. In: SALLES, Carlos Alberto (Org.). Processo civil de interesse público: o processo como instrumento de defesa social. São Paulo: Ed. Revista dos Tribunais; Associação Paulista do Ministério Público, 2003. p. 15-21.

${ }^{294}$ CARPI, TARUFFO e COLESANTI apontam, na doutrina italiana, as três principais vertentes sobre o conceito de jurisdição: a) justa composição da lide (CARNELUTTI), b) atuação da sanção (REDENTI) e c) atuação do direito substancial, por via secundária (MANDRIOLI e CHIOVENDA) (CARPI, Frederico; TARUFFO, Michele; COLESANTI, Vittorio. Commentario breve al Codice di Procedura Civile. Padova: CEDAM, 1984. p. 1-6). Para uma análise mais extensa da bibliografia histórica processual italiana, cf. BARBA, Stefano. Il Codice di Procedura Civile del Regno D'Italia: illustrato com tutte le monografie, annotazioni critiche, pere, circolari ministeriali e cc. Pubblicate dal 1866 ad oggi e disposte sistematicamente sotto i relativi e singoli articoli cui tendono ad illustrare. Milano: Casa Editrice Dottor Francesco Vallardi, 1898. Adotamos, contudo, o conceito de jurisdição como poder, função e atividade do Estado, porque mais consentâneo com o verdadeiro alcance da atividade desenvolvida pelo Poder Judiciário (CINTRA, Antonio Carlos de Araújo; DINAMARCO, Cândido Rangel; GRINOVER, Ada Pellegrini. Teoria geral do processo, cit., p. 115).

${ }^{295}$ MANCUSO, Rodolfo de Camargo. A ação civil pública como instrumento de controle judicial das chamadas políticas públicas. In: MILARÉ, Édis (Coord). Ação civil pública: Lei 7.347/1985 - 15 anos. 2. ed. São Paulo: Ed. Revista dos Tribunais, 2002. p. 751 e s.
} 
partir do exame dos interesses coletivos e difusos consagrados na Lei $\mathrm{n}^{\circ} 7.347 / 85$, justificando a ampla legitimação do Ministério Público no art. 129, inciso III, parte final, da Constituição da República. Há, inclusive, a percepção de que a ampliação do objeto da ação civil pública deve colimar a implementação dos direitos fundamentais. ${ }^{296}$

O problema fundamental desta forma de pensamento é o de se considerar a Lei n. ${ }^{\circ} 7.347 / 85$ como o objeto cognoscível ${ }^{297}$ para o entendimento das ações coletivas. Em verdade, o instrumento para a realização do direito não pode defini-lo. É o direito substancial, o verdadeiro objeto cognoscível, que irá definir o instrumento. Desta forma, a categoria jurídica estudada somente poderá ser compreendida a partir do fenômeno que lhe fundamentou a gênese.

O método que propomos, portanto, é o de posicionar os instrumentos legislativos no último estágio da cadeia lógico-conseqüencial. Em outras palavras, é o fundamento do direito coletivo, a sua gênese, que irá explicar o processo coletivo. $\mathrm{O}$ instrumento, portanto, será definido por sua causa primária, verdadeiro objeto do processo coletivo. $^{298}$

Ora, a positivação dos direitos sociais nas Constituições, a partir de 1919, deu origem a interesses e a direitos difusos, porque de titularidade dos componentes de toda a sociedade, não sendo possível a sua determinação. ${ }^{299}$ Antes mesmo de serem concebidos os chamados "grupos intermediários", 300 os direitos sociais já haviam sido institucionalizados. Entretanto, não se cogita, ainda hoje, da inserção expressa dos direitos fundamentais sociais como objeto da ação civil pública no Brasil.

Este fenômeno se explica ao verificarmos que as primeiras noções acerca da real necessidade de efetivação dos direitos sociais somente foram alcançadas após a renovação ética iniciada ao final da Segunda Guerra Mundial. Por outro lado, embora essa

\footnotetext{
${ }^{296}$ ALONSO JUNIOR, Hamilton. A ampliação do objeto das ações civis públicas na implementação dos direitos fundamentais. In: MILARÉ, Édis (Coord). Ação civil pública após 20 anos: efetividade e desafios. São Paulo: Ed. Revista dos Tribunais, 2005. p. 206 e s.

${ }^{297}$ Cf. TELLES JUNIOR, Goffredo da Silva. Tratado da consequência: curso de lógica formal. 6. ed. São Paulo: Juarez de Oliveira, 2003. p. 24 e s.

${ }^{298}$ Confira-se neste sentido: BEDAQUE, José Roberto dos Santos. Direito e processo: influência do direito material sobre o processo. 2. ed. 2. tir. São Paulo: Malheiros Ed., 2001. p. 15 ss.

${ }^{299}$ Os direitos fundamentais sociais preenchem as duas notas essenciais dos interesses difusos, destacadas por Ada Pellegrini GRINOVER: a titularidade de uma "série indeterminada de sujeitos" e a indivisibilidade do bem coletivo (GRINOVER, Ada Pellegrini. A problemática dos interesses difusos. In: (Coord.). A tutela dos interesses difusos. São Paulo: Max Limonad, 1984. p. 31). No mesmo sentido, NERY JÚNIOR, Nelson. Mandado de segurança coletivo. Revista de Processo, ano 15, n. 57, ano 15, p. 151, jan./mar. 1990.

${ }^{300} \mathrm{Cf}$. CAPPELLETTI, Mauro. Formações sociais e interesses coletivos diante da justiça civil, cit., p. 1 e s.
} 
renovação tenha sido declarada em 1948, ainda hoje o Poder Judiciário e a doutrina não fixaram o completo alcance da jurisdição constitucional. Estabeleceu-se, por conseguinte, uma crise metodológica, na medida em que o ordenamento jurídico reconhece direitos subjetivos constitucionalmente garantidos, mas a ciência processual ainda vacila sobre a possibilidade de sua concessão por meio da atividade jurisdicional.

A prevalecer o impasse, estaríamos a aceitar que é possível a existência de um direito material, estabelecido na mais importante norma do Estado, sem qualquer instrumento processual para a sua realização, o que é inadmissível do ponto de vista lógico e, sobretudo, ético.

Destarte, a percepção de que o processo coletivo é o produto da mesma construção doutrinária precursora da criação das denominadas gerações de direitos fundamentais, possibilitou a compreensão de que o instrumento processual não está sendo utilizado em sua plenitude, não obstante a plena eficácia garantida àqueles direitos no art. $5^{\circ}, \S 1^{\circ}$, da Constituição da República.

Enquanto a doutrina tem se concentrado, de maneira geral, no exame dos aspectos técnico-jurídicos concernentes à relação jurídica processual e aos efeitos da coisa julgada no processo coletivo, o campo de abrangência do objeto das ações coletivas tem se circunscrito às hipóteses previstas no art. $1^{\circ}$ da Lei $n^{\circ} 7.347 / 85$, que paulatinamente vai se ampliando. $^{301}$

Observa-se, ainda, contínua interferência do legislador, na tentativa de obstar o exame de determinadas matérias pelo Poder Judiciário, neutralizando-o. São exemplos o parágrafo único do art. $1^{\circ}$, acrescentado pela Medida Provisória $\mathrm{n}^{\mathrm{o}}$ 2.180-35, de 24.08.2001, em vigor conforme o art. $2^{\circ}$ da $E C n^{\circ} 32 / 2001$, e o art. 16, com redação alterada pela Lei $\mathrm{n}^{\circ} 9.494$, de 10.09.1997, ambos da Lei $\mathrm{n}^{\circ} 7.347 / 85 .^{302}$

Esta inadmissível afronta ao art. $5^{\circ}$, inciso XXXV, da Constituição da República, matriz do princípio da inafastabilidade, tem sido tolerada em virtude da crise metodológica instaurada pela errônea interpretação do art. $2^{\circ}$ da Lex Legum. Com efeito, o princípio da separação dos poderes, interpretado à luz do chamado Estado liberal, impõe

\footnotetext{
${ }^{301}$ Cf. Lei ${ }^{\circ} 8.884 / 94$, a Lei $n^{\circ} 10.257 / 01$ e a Medida Provisória ${ }^{\circ}$ 2.180-35/01, que ampliaram o objeto da Lei de Ação Civil Pública.

${ }^{302}$ Sobre o equívoco desta última providência legislativa, cf. GRINOVER, Ada Pellegrini. A ação civil pública no STJ. Revista de Processo, São Paulo, ano 25, p. 20 e s. jul./set. 2000.
} 
uma indevida neutralização do Poder Judiciário em relação aos fins do Estado, ${ }^{303}$ com deletérias consequências para a afirmação da democracia no Brasil. O reconhecimento, no âmbito constitucional, de um Estado de bem-estar social, expressamente encampado pelo art. $3^{\circ}$ da Constituição Federal, importa na inarredável conclusão de que o Poder Judiciário deve participar ativamente do processo democrático, avaliando a atividade finalística das demais formas de expressão do poder estatal. E tal se dá, no processo coletivo, através da efetivação dos direitos fundamentais, indispensáveis para a consecução dos objetivos do Estado brasileiro. ${ }^{304}$

A partir de tais premissas, conclui-se que constitui dever do Poder Judiciário avaliar e corrigir as políticas públicas desenvolvidas pelas demais formas de expressão do poder estatal que afrontem os direitos fundamentais. A função da atividade jurisdicional é, portanto, a de interceder para que tais direitos sejam assegurados àqueles que se encontrem marginalizados do processo democrático, sendo inevitável a molecularização da lide. ${ }^{305}$

Conferindo plenitude ao art. $2^{\circ}$ da Constituição Federal, o processo coletivo é o instrumento institucional adequado para esta correção, sendo indevida, ao nível subconstitucional, qualquer redução de seu alcance constitucional primário.

A ação coletiva, por conseguinte, em especial a ação civil pública, deve ser visualizada como mero instrumento para a efetivação dos direitos fundamentais sociais, permitindo-se a maior fluência dos institutos e categorias jurídicas necessários à respectiva realização. Inverte-se, pois, o parâmetro interpretativo, de forma que os instrumentos processuais não poderão representar óbice à efetivação dos direitos fundamentais, mas parâmetro de discussão sobre a melhor forma de sua satisfação.

Mas esta visão restringe-se à efetivação dos direitos fundamentais, notadamente os de segunda geração, assegurados no art. $6^{\circ}$ da Constituição Federal. Como a concreção dos direitos fundamentais é parâmetro normativo constitucional direcionado a

\footnotetext{
${ }^{303}$ PEDRAZ PENALVA, Ernesto. Constitucion, jurisdiccion y proceso, cit., p. 41-42.

${ }^{304}$ Ada Pellegrini GRINOVER assevera, com absoluta precisão, que a neutralidade política do juiz consiste na proibição de atividade político-partidária, mas o "juiz brasileiro não tem como se colocar fora do sistema e contra as finalidades do Estado, nem a justiça sofre freqüente distorção em razão de sua politização" (GRINOVER, Ada Pellegrini. A responsabilidade do juiz brasileiro, cit., p. 22).

${ }^{305}$ Expressão empregada, com grande propriedade, por Kazuo Watanabe.
} 
todas as formas de expressão do poder estatal, ${ }^{306}$ o exame e a correção de políticas públicas pelo Poder Judiciário no processo coletivo é sua consequência reflexa.

Ocorre que o exame de políticas públicas no processo coletivo pelo Poder Judiciário não se faz de forma indiscriminada, porquanto sua vocação é a de salvaguardar, mediante atividade tipicamente jurisdicional, a Constituição dos atos dos demais poderes que vulnerem suas normas, princípios e objetivos. Desta forma, imperativo que se estabeleça o âmbito de cognição das políticas públicas no processo coletivo em cotejo com a necessária efetivação dos direitos fundamentais pelo Estado brasileiro. A demarcação do âmbito de cognição das políticas públicas é essencial para que não haja injustificada invasão nas atribuições constitucionais dos demais poderes, com contaminação, por vício insanável de inconstitucionalidade $\left(\mathrm{CF}\right.$, art. $\left.2^{\circ}\right)$, do processo coletivo, e possível crise institucional entre as formas de expressão do poder estatal.

O controle de políticas públicas não é, portanto, o objeto do processo coletivo. ${ }^{307}$ As políticas públicas desenvolvidas pelo Executivo e pelo Legislativo serão alvo da cognição do juízo, na medida em que representarem violação aos direitos fundamentais sociais, estes sim verdadeiro objeto do processo coletivo.

\section{Análise do princípio da inafastabilidade sob a ótica dos direitos fundamentais}

O princípio da inafastabilidade, também denominado princípio da indeclinabilidade, ${ }^{308}$ princípio do direito de ação ${ }^{309}$ ou princípio da proteção judiciária, ${ }^{310}$

\footnotetext{
${ }^{306}$ Nas palavras de José Carlos Vieira DE ANDRADE, citando KRÜGER, “se antes os direitos fundamentais só existiam no quadro das leis, hoje as leis só valem no quadro dos direitos fundamentais" (ANDRADE, José Carlos Vieira de. Os direitos fundamentais na Constituição Portuguesa de 1976, cit., p. 38-39).

${ }^{307}$ Se a pretensão processual é definida pela afirmação de um direito, e o objeto do litígio centra-se no pedido, conforme discorre Karl Heinz SCHWAB (El objeto litigioso en el proceso civil. Trad. Tomas A. Banzhaf Der Streitgegenstand im Zivilprozess. Buenos Aires: Ediciones Juridicas Europa-America, 1968. p. 241252), então, segundo nossa proposição, somente os direitos fundamentais, ou a pretensão relativa aos bens da vida por eles protegidos, pode constituir o objeto do processo coletivo.

${ }^{308}$ ALVIM, Arruda. Manual de direito processual civil. 7. ed. São Paulo: Ed. Revista dos Tribunais, 2001. v. 1, p. 183.

${ }^{309}$ NERY JUNIOR, Nelson. Princípios do processo civil na Constituição Federal. 6. ed. São Paulo: Ed. Revista dos Tribunais, 2000. p. 94 e s.

${ }^{310}$ WATANABE, Kazuo. Da cognição no processo civil. São Paulo: Ed. Revista dos Tribunais, 1987. p. 21.
} 
foi sinteticamente ${ }^{311}$ enunciado no art. $5^{\circ}$, inciso XXXV, da Constituição Federal de 1988, estabelecendo que "a lei não excluirá da apreciação do Poder Judiciário lesão ou ameaça a direito". A indigitada norma encontra seu complemento infraconstitucional na letra do art. 126 do Código de Processo Civil, segundo o qual o juiz "não se exime de sentenciar ou despachar alegando lacuna ou obscuridade na lei”. O art. $4^{\circ}$ da Lei de Introdução ao Código de Processo Civil reitera o dever de prestação jurisdicional mesmo em caso de obscuridade da lei.

O princípio da inafastabilidade, pois, dá suporte lógico ao disposto no art. $4^{\circ} \mathrm{da}$ Lei de Introdução ao Código Civil e no art. 126 do Código de Processo Civil, os quais sustentam o sistema de integração do direito. De nada adiantaria a declaração expressa do princípio da inafastabilidade, se não se garantisse ao juiz a possibilidade de prestar jurisdição em qualquer situação jurídica assegurada, mesmo que não previstos os respectivos mecanismos legais pelo legislador. ${ }^{312}$

O tema em questão guarda umbilical ligação com o postulado do acesso à justiça, tão difundido no direito processual contemporâneo. ${ }^{313} \mathrm{~A}$ visão individualista do Estado liberal não é mais tolerada no direito contemporâneo, pelo que, diante de sua finalidade social, o ordenamento jurídico deve ajustar-se ao compromisso constitucional de atuar pelo bem-comum de todos os cidadãos, na esteira do que dispõe o art. $3^{\circ}$ da Constituição Federal.

Desta forma, o acesso à justiça não mais pode ser obstaculizado por procedimentos estruturados a partir de uma visão eminentemente individualista. $\mathrm{O}$ Estado há de viabilizar o acesso à ordem jurídica justa ${ }^{314}$ a todos os cidadãos, criando mecanismos que permitam a atuação coletivizada e a isenção dos encargos da demanda. É igualmente

\footnotetext{
${ }^{311} \mathrm{O}$ princípio da inafastabilidade, embora sintético, provoca inúmeras repercussões no ordenamento jurídico. A forma sintética das disposições constitucionais, entretanto, é a mais apropriada para as Cartas constitucionais, como ressalta Piero CALAMANDREI (Potere giudiziario e Suprema Corte Costituzionale. Appendici - I Projetti di Riforma. In: RIGANO, Francesco. Costituzione e Potere Giudiziario: ricerca sulla formazione delle norme costituzionali, cit., p. 263).

${ }^{312}$ Francesco CARNELUTTI afirma, neste passo, que o processo é o método pelo qual se obtém a "pronúncia oficial do comando jurídico", preexistindo, ou não, lei. Ainda segundo o referido autor, "com o método legislativo se obtém uma lex generalis; com o método jurisdicional ou processual se obtém uma lex specialis" (CARNELUTTI, Francesco. Dirito e processo. Napoli: Morano, 1958. p. 18-19).

${ }^{313}$ CINTRA, Antonio Carlos de Araújo; DINAMARCO, Cândido Rangel; GRINOVER, Ada Pellegrini. Teoria geral do processo, cit., p. 123.

${ }^{314}$ Segundo Kazuo WATANABE, o acesso à ordem jurídica justa requer a tomada de uma "nova postura mental", de tal forma que o intérprete há de assumir a perspectiva do destinatário das normas jurídicas (WATANABE, Kazuo. Acesso à justiça na sociedade moderna. In: GRINOVER, Ada Pellegrini; DINAMARCO, Cândido Rangel; WATANABE, Kazuo. Participação e processo. São Paulo: Ed. Revista dos Tribunais, 1988. p. 128).
} 
dever do Estado propiciar prestação jurisdicional justa em todas as situações fáticas que se apresentarem, independentemente de expressa regulamentação subconstitucional da matéria.

O grande relevo conferido à lei decorreu da necessidade de contenção do poder dos governantes, salvaguardando-se direitos individuais tão caros ao liberalismo. Entretanto, não se pode mais admitir que o objeto do direito seja, exclusivamente, a lei. A Ciência do Direito há de ampliar seus horizontes, permitindo a abertura do sistema para situações inovadoras e que exijam soluções igualmente inovadoras. ${ }^{315}$

O positivismo, como método de pensamento, tem, neste contexto, a virtude de edificar o sistema para a aplicação do direito segundo padrões científicos seguros. Entretanto, a norma jurídica não poderá ser considerada o único objeto desta ciência, como preconizado por Hans Kelsen. O conceito de sistema, portanto, haverá de ultrapassar os estreitos limites da lei, alcançando efetiva organicidade, a fim de habilitar o aplicador do direito a apresentar as melhores e mais justas soluções.

Em um Estado lastreado no bem-estar-social, é imperativo que o sistema esteja aberto aos influxos programáticos de execução no tempo, materializados nas Constituições. Não se pode mais falar em aplicação da lei apenas por força de sua autoridade, ${ }^{316}$ mas sim dentro de um contexto orgânico de todo o sistema normativo. Impende, pois, a aplicação da lei segundo os fins do Estado e, para tanto, o positivismo jurídico não possui os mecanismos corretivos necessários.

Propugnamos, portanto, que o respeito à lei é indissociável do Estado de Direito. Entretanto, não poderá a lei constituir obstáculo à consecução dos objetivos

\footnotetext{
${ }^{315}$ Cf. VARELA, Casimiro A. Fundamentos constitucionales del derecho processual. Buenos Aires: ADHoc, 1999. p. 160-161.

${ }^{316}$ Em análise do impacto causado pelo controle judicial de constitucionalidade, Lorenzo CHIEFFI aponta a alteração de concepção do princípio da legalidade. A jurisdição exercida por um técnico que dicit ius, com aplicação na norma abstrata da lei ao caso concreto, instituída pelo Parlamento, por parte da investidura do povo, era, no Estado liberal, a única "sorgente di sovranità" (fonte de soberania). A razão desta rígida interpretação da legalidade, para o "automatismo jurídico" kelseniano, que reencontra em Piero Calamandrei um convincente defensor, foi sustentada pela teoria de que, se de um lado considerava-se a administração (incluída a judiciária) como um "mero braço executivo da vontade política", de outro aproximava-se a lei de um ato preordenado ao simples registro da vontade do partido e da "contínua colisão das classes que lutam para a sua elevação". CHIEFFI menciona a preocupação do constituinte de que os magistrados, na salvaguarda dos direitos fundamentais, saíssem de sua neutralidade, para transformarem-se em "interprete libero", introduzindo mecanismo exegético diverso da tradição jurídica, o que poderia levar a um "governo dei giudici" (governo dos juízes) (CHIEFFI, Lorenzo. La magistratura: origine del modello costituzionale e prospettive di riforma. Napoli: Casa Editrice Dott. Eugenio Jovene, 1998. p. 23-26).
} 
erigidos pelo próprio Estado, porque tal situação resultaria em absoluta incoerência entre o instrumento e o seu criador.

A Declaração dos Direitos Humanos representou impacto direto na soberania dos Estados. Com efeito, a constatação de que determinados direitos, intrinsecamente anelados à dignidade humana, não estavam sendo reconhecidos por diversos Estados, imunizados por sua soberania, produziu movimento tendente à respectiva declaração e ao paulatino movimento de assimilação interna.

Os direitos fundamentais, portanto, passaram a integrar o ordenamento jurídico dos Estados, de forma a permitir uma renovação de princípios e objetivos que se expandiu através das Constituições. A proteção aos direitos fundamentais torna-se, cada vez mais, objetivo a ser atingido pelos Estados soberanos, e não mera declaração de princípios destituída de vinculação jurídica. Tal ocorreu no Brasil a partir de 1985, em meio ao processo de democratização do país, com a ratificação paulatina de relevantes tratados internacionais de direitos humanos. ${ }^{317}$

É de fácil percepção o paulatino reconhecimento formal dos direitos fundamentais, mas ao mesmo tempo a vacuidade do discurso sobre sua efetivação é igualmente constatada. $^{318}$

Desde a promulgação da Constituição Federal de 1988, cujos exatos objetivos foram estabelecidos no correlato art. $3^{\circ}$, o posicionamento político do Poder Legislativo foi lento e gradual, observando-se uma indiscutível apatia dos poderes Executivo e Judiciário. Enquanto o primeiro é recalcitrante na utilização dos recursos públicos para a concretização de políticas públicas aneladas às reais necessidades do Estado brasileiro, este último, sob o pálio de uma pretensa inação institucionalizada, aguarda pacientemente a evolução do arcabouço legislativo. ${ }^{319}$

\footnotetext{
${ }^{317}$ Neste sentido, a ratificação da Convenção Interamericana para Prevenir e Punir a Tortura, de 20 de julho de 1989, constitui marco inicial do processo de incorporação de tratados internacionais de direitos humanos pelo direito brasileiro. Cf. PIOVESAN, Flávia. A Constituição Brasileira de 1988 e os tratados internacionais de proteção dos direitos humanos. In: DIREITOS humanos: visões contemporâneas. Associação Juízes para a Democracia. São Paulo: Associação Juízes para a Democracia, 2001. p. 39-41.

${ }^{318}$ MORANGE, Jean. Droits de l'homme et libertés publiques, cit., p. 390-397.

${ }^{319}$ Certos direitos fundamentais somente foram reconhecidos por políticas públicas levadas a efeito pelo Poder Legislativo quase vinte anos após a promulgação da Constituição da República. É o caso da Lei n. ${ }^{\circ}$ 11.340, de 7 de agosto de 2006, a "Lei Maria da Penha", que em seu art. $3^{\circ}, \S 1^{\circ}$, dispõe: "O poder público desenvolverá políticas que visem garantir os direitos humanos das mulheres no âmbito das relações domésticas e familiares no sentido de resguardá-las de toda forma de negligência, discriminação, exploração, violência, crueldade e opressão". O art. 37 refere-se à defesa dos direitos metaindividuais previstos naquela lei.
} 
Estamos, portanto, de acordo com o pensamento de Fábio Konder Comparato, para quem as normas relativas aos direitos fundamentais, inclusive aquelas de princípio, são de aplicação direta e imediata, de tal forma que, os magistrados, no exercício da função jurisdicional, devem se orientar pelos objetivos fundamentais da organização política brasileira, previstos no art. $3^{\circ}$ da Constituição Federal. ${ }^{320}$ Os órgãos jurisdicionais, pois, não podem se recusar a examinar as lides que lhes são submetidas, ao fundamento de que não constituem órgão político, sob pena de quebra do supremo valor ético: a dignidade humana.

Porque direitos constitucionais subjetivos, cristalizados no art. $6^{\circ}$ da Constituição Federal, os direitos fundamentais sociais não dependem de qualquer reconhecimento no plano subconstitucional. Ao revés, sua captação dar-se-á através da interpretação da Constituição Federal e dos tratados que a ela venham a se fundir, nos termos do que dispõe o respectivo art. $5^{\circ}, \S 3^{\circ}$, com a redação que lhe deu a Emenda Constitucional $n^{\circ} 45$.

Não se está, evidentemente, preconizando a abertura indiscriminada do sistema no trato do processo coletivo. Ao revés, o que sustentamos é que as normas infraconstitucionais, que eventualmente impeçam ou mesmo dificultem a efetivação dos direitos fundamentais, são inconstitucionais e, portanto, não podem ser aplicadas pelo julgador. As leis, atos normativos e os atos administrativos praticados pelos poderes Legislativo e Executivo constituem políticas públicas e, portanto, devem se harmonizar com os direitos fundamentais sociais e com os núcleos constitucionais de irradiação.

A abertura do sistema, por conseguinte, é meramente episódica e decorre da proibição de resistência instrumental aos direitos fundamentais, princípio implícito que extraímos da interpretação sistemática da Constituição Federal.

Segundo o princípio da proibição de resistência instrumental aos direitos fundamentais, nenhuma política pública, oriunda do Poder Legislativo ou do Poder Executivo, poderá se converter, comissiva ou omissivamente, em instrumento de resistência à efetivação dos direitos fundamentais. Logo, não somente os atos administrativos e de governo poderão ser examinados pelo Poder Judiciário, como também

\footnotetext{
${ }^{320}$ COMPARATO, Fábio Konder. O papel do juiz na efetivação dos direitos humanos. In: DIREITOS humanos: visões contemporâneas, cit., p. 29.
} 
as normas subconstitucionais, as quais constituem o produto de uma política pública mais ampla daqueles poderes.

É neste contexto que o princípio da inafastabilidade será integralmente assimilado. $\mathrm{O}$ art. $5^{\circ}$, inciso XXXV, da Constituição Federal não possui mera significância formal, mas atinge desdobramentos vinculados à manutenção dos objetivos fundamentais do Estado brasileiro. ${ }^{321}$ Em ultima ratio, o princípio da inafastabilidade é o mecanismo de resgate da própria democracia, porque permite a efetiva e legítima inserção da população no seu discurso.

Enquanto prevalecer entre nós o pensamento positivista redutor na compreensão do processo e da própria jurisdição, não há esperanças para a construção de uma sólida democracia. ${ }^{322} \mathrm{O}$ sistema representativo não atendeu às expectativas mundiais, porquanto o consentimento dos cidadãos traduziu-se em fórmula ineficaz para a consecução dos objetivos maiores do Estado, causando desvios sociais e econômicos que resultaram em abissal distanciamento entre a população e seus mínimos direitos fundamentais. $^{323}$

Compreendemos, portanto, que a legitimidade democrática deve ser restabelecida à população através do processo coletivo, a fim de que o discurso democrático não se torne uma mera utopia. O Estado, por intermédio de suas formas de

\footnotetext{
${ }^{321}$ Nas palavras de Kazuo Watanabe, o princípio da inafastabilidade "não assegura apenas o acesso formal aos órgãos judiciários, mas, sim, o acesso à Justiça que propicie a efetiva e tempestiva proteção contra qualquer forma de denegação da justiça e também o acesso à ordem jurídica justa" (WATANABE, Kazuo. Tutela antecipatória e tutela específica das obrigações de fazer e não fazer: arts. 273 e 461 do CPC. Ajuris: revista da Associação dos Juízes do Rio Grande do Sul, Porto Alegre, v. 23, n. 66, p. 160-161, mar. 1996).

${ }^{322} \mathrm{O}$ princípio da participação popular pode ser realizado, segundo Vicenzo VIGORITI, por intermédio do processo, em especial através da tutela jurisdicional dos interesses coletivos (VIGORITI, Vicenzo. Interessi collettivi e processo: la legittimazione ad agire. Milano: Giuffrè, 1979. p. 12 e s). Esta abertura de pensamento deve ser realizada, a fim de que a jurisdição atinja todos os seus escopos. O processo coletivo para a efetivação dos direitos fundamentais sociais leva este conceito à sua máxima expressão, na medida em que a garantia de igualdade substancial entre os componentes do grupo social implica na realização da democracia social.

${ }^{323}$ Interessante é a seguinte manifestação de Catherine AUDARD: "Nosso sistema social e cultural tendo-se tornado 'pós-metafísico', como diz Habermas, será ainda possível encontrar um fundamento para o princípio da legitimidade democrática? Seria necessário recorrer a uma linguagem e a uma argumentação que levassem em conta o 'desencantamento do mundo' (Max Weber), isto é, 'da ausência de qualquer critério independente e anterior da justiça' (Rawls) ou 'do desaparecimento dos pontos das referências da certeza' (Lefort). Como restaurar os fundamentos das instituições e das práticas democráticas num contexto de crise da razão teórica e prática? Como continuar afirmando a primazia do justo sobre o bom, da lei sobre as preferências, em meio à 'guerra dos deuses'? Definir a legitimidade democrática pelo simples 'consentimento' dos cidadãos foi uma ação fracassada, tanto o exemplo do nazismo, quanto das diferentes formas de totalitarismo mostraram a que ponto tal consentimento podia estar alienado ou equivocado. Não queremos mais esta suposta democracia. É necessário encontrar outro caminho" (AUDARD, Catherine. O princípio de legitimidade democrática e o debate Rawls-Habermas. In: ROCHLITZ, Rainer (Coord.). Habermas: o uso público da razão. Rio de Janeiro: Tempo Brasileiro, 2005. p. 81-82).
} 
expressão do poder, deve criar mecanismos de legitimação e de realização da democracia, consoante claramente dispõe 0 art. $3^{\circ}$ da Constituição Federal. Todavia, falhando os poderes Executivo e Legislativo na implementação de tais mecanismos, em decorrência de políticas públicas divorciadas dos objetivos fundamentais do Estado, cumpre ao Poder Judiciário colmatar a lacuna, viabilizando o acesso da população à ordem jurídica justa.

O direito de ação constitui direito fundamental, ${ }^{324}$ conforme claramente dispõe a Constituição Federal, contrapondo-se ao dever constitucional de prestação jurisdicional pelo Estado. ${ }^{325}$ Conquanto o destinatário principal do princípio da inafastabilidade seja o Poder Legislativo, ${ }^{326}$ o comando constitucional contido no art. $5^{\circ}$, inciso XXXV, da Constituição Federal vincula a todos os agentes públicos, ${ }^{327}$ inclusive os órgãos do Poder Judiciário.

Existindo direito subjetivo amparado $\left(\mathrm{CF}\right.$, art. $\left.6^{\circ}\right)$, bem como a alegação de lesão a este direito $\left(\mathrm{CF}\right.$, art. $5^{\circ}$, inciso XXXV), o Poder Judiciário está constitucionalmente vinculado a prestar jurisdição, ${ }^{328}$ não podendo se valer de argumentos externos à atividade jurisdicional $^{329}$ para bloquear o acesso dos cidadãos ao processo. Em assim agindo, o Poder Judiciário viola o princípio da inafastabilidade e o art. $3^{\circ}$ da Constituição Federal, de tal modo que o ato produzido não estará sujeito à imunização pela coisa julgada.

Por outro lado, o princípio da inafastabilidade deve ser cotejado com o sistema ético de referência do Estado. ${ }^{330}$ Os direitos fundamentais foram enriquecidos com uma enorme carga ética, decorrente do consenso das nações. Ética, em matéria de direitos

\footnotetext{
${ }^{324} \mathrm{O}$ direito de ação é, na visão de Marcus Orione Gonçalves CORREIA, um direito social, ainda que liberdade pública (CORREIA, Marcus Orione Gonçalves. Poder constitucional de ação, direitos sociais e Estado democrático de direito. 2000. Tese (Livre-Docência) - Faculdade de Direito, da Universidade de São Paulo, São Paulo, 2000. p. 120-138).

${ }^{325}$ Luigi Paolo COMOGLIO, ao caracterizar a ação como direito subjetivo público, afirma: "Malgrado importantes dissensões contrárias, a concepção da ação como direito subjetivo contra o Estado à prestação da tutela jurisdicional é, de longo tempo, afirmada na doutrina juspublicista continental" (COMOGLIO, Luigi Paolo. La garanzia costituzionale dell'azione ed il processo civile. Padova: Cedam, 1970. p. 51).

${ }^{326} \mathrm{~A}$ primeira consequência do princípio da inafastabilidade do controle judiciário, segundo Ada Pellegrini GRINOVER, é o impedimento, ao Poder Legislativo, de supressão ou restrição da atividade judiciária. A segunda consequência é o direito ao devido processo legal (GRINOVER, Ada Pellegrini. Os princípios constitucionais e o Código de Processo Civil, cit., p. 17-19).

${ }^{327}$ NERY JUNIOR, Nelson. Princípios do processo civil na Constituição Federal, cit., p. 94.

${ }^{328}$ Quando nos referimos ao Poder Judiciário, evidentemente o fazemos tomando como pressuposto o princípio da unidade da jurisdição, segundo o qual todos os juízes são potencialmente investidos de toda a jurisdição, sendo limitados concretamente em razão das regras de competência (Cf. ALLORIO, Enrico. Commentario del Codice di Procedura Civile: Art. 1-68. Torino: Unione Tipografico-Editrice Torinese, 1973. Livro 1, t. 1, p. 4-5).

${ }^{329}$ Ver supra, Capítulo II, Seções 3 e 7.

${ }^{330}$ Ver supra, Capítulo I, Seção 2.
} 
fundamentais, consiste em toda a conduta tendente à efetivação destes direitos, através de sua completa irradiação formal e material.

Ora, se o Poder Judiciário, adotando conceitos externos à jurisdição, bloqueia o acesso dos cidadãos ao processo, age arbitrariamente, porque desconsiderou o comando inserto no art. $3^{\circ}$ da Constituição Federal. ${ }^{331}$

A situação em tela é especialmente grave, porquanto, ao contrário das demais formas de expressão do poder estatal, o Poder Judiciário não está sujeito a controle dos atos exclusivamente jurisdicionais. As decisões do órgão de superposição máxima que contrariem a efetivação dos direitos fundamentais, embora não estejam sujeitas a mecanismos de soberania interna para revisão, salvo a alteração de entendimento do próprio Supremo Tribunal Federal, representam a imediata inserção do Estado brasileiro no rol dos países que contrariam o sistema normativo internacional de proteção dos direitos fundamentais.

O Poder Judiciário, portanto, tem o dever constitucional de permitir a discussão democrática sobre a violação dos direitos fundamentais sociais, mesmo decorrente da omissão de políticas públicas pelo Estado. ${ }^{332}$ Esta abertura se faz através da concessão do direito de ação, permitindo-se, na dialética do processo, a cognição sobre a alegada lesão a direito social fundamental e o realinhamento eficaz das políticas públicas, por meio da plasticidade dos provimentos jurisdicionais. ${ }^{333}$

\footnotetext{
${ }^{331}$ Segundo Luigi Paolo COMOGLIO, a afirmação dos direitos fundamentais nos planos interno e internacional exigiu o reconhecimento de uma relação instrumental (rapporto strumentale) de meio e fim, com a possibilidade de tutela jurisdicional daqueles direitos invioláveis. O processo como garantia fundamental, conforme discorre o autor, é inspirado no princípio nullum jus sine remedium (COMOGLIO, Luigi Paolo. Etica e tecnica del "giusto processo". Torino: G. Giappichelli, 2004. p. 158).

${ }^{332} \mathrm{~A}$ partir do modelo de Estado adotado, a doutrina distingue dois escopos do processo. O Estado liberal é catalogado como Estado reativo, no sentido de que se mantém inerte. O Estado ativo, correspondente ao Estado social, é caracteristicamente pró-ativo, dotado de objetivos a serem alcançados (DAMAŠKA, Mirjan R. I volti della giustizia e del potere: analisi comparatistica del processo. Bolonha: Il Mulino, 2002. p. 133-171). O Estado brasileiro, segundo esta classificação, é indiscutivelmente ativo, consoante inferência que se faz do contido no art. $3^{\circ}$ da $\mathrm{CF}$, de forma que o suprimento de omissões passa a ser da própria natureza da atividade jurisdicional.

${ }^{333}$ Precioso é o escólio de Ada Pellegrini GRINOVER acerca do papel dos tribunais na concretização dos direitos fundamentais: "A norma constitucional - uma norma necessariamente vaga e genérica - exige uma interpretação-atuação acentuadamente evolutiva, a ser efetuada nos tribunais, que alguns juristas alemães chamaram rechtsschöpferische Konkretisierung. O processo serve, assim, como instrumento de atuação de certas fórmulas constitucionais, operando a transformação do mero derecho declarado em derecho garantizado. Porque os direitos fundamentais, abstratamente formulados pela Constituição, só podem ser afirmados, positivados e concretizados pelos tribunais" (GRINOVER, Ada Pellegrini. As garantias constitucionais do direito de ação. São Paulo: Ed. Revista dos Tribunais, 1973. p. 15).
} 
O processo coletivo é instrumento natural para esta discussão dialética, tendente à realização da democracia social. ${ }^{334}$

\section{O processo coletivo como instrumento para a efetivação dos direitos fundamentais}

Ao analisarmos a evolução histórica das ações coletivas, seja no sistema da common law ou no sistema da civil law, ${ }^{335}$ concluímos que a percepção de interesses ligados a determinados grupos justificou a criação de mecanismos processuais que garantissem a respectiva proteção. Mesmo ao remontarmos os vestígios romanos da ação popular, constatamos que o fundamento para a legitimação de um dos integrantes do grupo ou da coletividade para a defesa dos seus interesses reside na concepção de que há direitos que extravasam a esfera individual, decorrentes de interesses metaindividuais ou difusos.

Interesses metaindividuais, portanto, decorrem de uma realidade fática ancestral do homem: a formação de grupos sociais básicos. ${ }^{336}$ A actio popularis romana, precursora da ação popular, não seria concebível sem a noção de povo ou nação e sua relação com a res publica. ${ }^{337}$ Os agrupamentos humanos pressupõem a existência de idênticos interesses entre os seus componentes. Dos variados interesses possíveis, alguns serão, indubitavelmente, idênticos. Se estes interesses forem juridicamente amparados, haverá uma diversidade de titulares de um mesmo direito.

Esta é a gênese do direito coletivo.

O interesse deve ser juridicamente amparado. Interesses não-reconhecidos pelo ordenamento jurídico não geram direito e, portanto, não são exigíveis. Daí o indispensável papel da jurisdição para o reconhecimento dos direitos metaindividuais, porquanto é a

\footnotetext{
${ }^{334}$ Roberto GARGARELLA, após afirmar, com razão, que os juízes cumprem seu papel democrático ao atenderem aos direitos sociais, cita importantes precedentes na África do Sul, na Índia e na Colômbia, nos quais o Poder Judiciário promoveu a concessão de direitos fundamentais (GARGARELLA, Roberto. Democracia deliberativa e o papel dos juízes diante dos direitos sociais. In: SOUZA NETO, Cláudio Pereira de; SARMENTO, Daniel (Coords.). Direitos sociais: fundamentos, judicialização e direitos sociais em espécie. Rio de Janeiro: Lumen Juris, 2008. p. 207-227).

${ }^{335}$ Cf. MENDES, Aluisio Gonçalves de Castro. Ações coletivas no direito comparado e nacional. São Paulo: Ed. Revista dos Tribunais, 2002. p. 43 e s.

${ }^{336}$ Sob influência de Arthur Schopenhauer, o sociólogo organicista Ferdinand Julius Tönnies desenvolve a distinção entre "sociedade" e "comunidade", formas básicas de grupos sociais que se formam, respectivamente, pela vontade e pela razão. Cf. ARON, Raymond. As etapas do pensamento social. São Paulo: Martins Fontes, 2002.

${ }^{337}$ MANCUSO, Rodolfo de Camargo. Ação popular: proteção do erário, do patrimônio público, da moralidade administrativa e do meio ambiente. 5. ed. São Paulo: Ed. Revista dos Tribunais, 2003. p. 42 e s. (Controle jurisdicional dos atos do Estado; v. 1/coord. Eduardo Arruda Alvim et al.).
} 
atividade jurisdicional que estabelecerá o âmbito proteção jurídica para o interesse manifestado.

O exame da evolução histórica das ações coletivas revela o constante esforço da jurisdição, em suas diversas formas de manifestação ao longo dos séculos, para a equalização entre a necessidade de amparo dos interesses do grupo social e a manutenção da coerência do ordenamento jurídico. Este labor varia no tempo e no espaço, mas decorre de contínuo esforço intelectual do gênio humano.

Os direitos sociais atingem um número indeterminado de pessoas, porquanto o seu âmbito pretendido de abrangência é o conjunto de toda a sociedade. A sociedade é detentora dos direitos fundamentais sociais, de forma que não há como se determinar, na relação jurídica processual, quais seriam exatamente todos o seus beneficiários. Ante, pois, a indiscutível indeterminação dos destinatários dos direitos fundamentais sociais, conclui-se que se encontram eles no rol dos interesses e direitos difusos. ${ }^{338}$

A lesão aos direitos fundamentais sociais, entendidos como interesses ou direitos difusos, deve ser examinada e eventualmente reparada através do processo coletivo, único instrumento apto à efetivação daqueles direitos. ${ }^{339}$ No atual quadro de instrumentos processuais que se encontram no âmbito do processo coletivo, certamente a ação civil pública é a via adequada, mesmo que ainda não adaptada, para a proteção dos direitos fundamentais sociais. ${ }^{340}$

\footnotetext{
${ }^{338}$ Discorrendo sobre os direitos difusos como categoria jurídica amparável, cita Vittorio DENTI a decisão da Corte di Cassazione, as duas sentenças da Sezioni Unite 9 marzo 1979 n. 1463 e 6 ottobre 1979 n. 5172 , nas quais se admitiu a possibilidade de se reconhecer que um bem de natureza indivisível poderia ser reconhecidamente sujeito à fruição, desde que estivesse em jogo "diritti fondamentali ed inviolabilli" (direitos fundamentais e invioláveis), referindo-se ao direito ambiental, entrelaçado com o direito à vida, à saúde, ou seja, ao ambiente salubre. Logo, salienta indigitado autor, reconhecendo uma situazioni giuridiche precostituite (situação jurídica pré-constituída), de natureza real e obrigatória, "absoluta", confrontável com a administração pública, admitindo a "possibilidade, pelo juiz ordinário, de invadir a esfera pública, também com provimento do tipo inibitório" (DENTI, Vittorio. Profili civilistici della tutela degli interessi diffusi. In: STANZANI, Davide; FIORE, Adriano (a cura di). Strumenti per la tutela degli interessi diffusi della collettività. Rimini: Maggioli, 1982. p. 41-53).

${ }^{339}$ A propósito do assunto, precisa é a lição de Walter J. HABSCHEID acerca do conceito de processo civil: "o meio pelo qual se pode fazer valer, em caso de controvérsia, a norma de direito material, e se essa tem por escopo característico a realização do ordenamento jurídico garantido pelo direito substancial, é consequência direta a proporcionalidade entre o grau de eficiência do sistema processual civil e o grau de efetiva concretização e atuação do direito material" (HABSCHEID, Walter J. Introduzione al diritto processuale civile comparato. Rimini: Maggioli, 1985. p. 118).

${ }^{340}$ Sobre o aprimoramento das técnicas processuais para que se atinjam as finalidades do processo, valiosos são os ensinamentos de Ada Pellegrini GRINOVER: "A técnica processual deve ser revisitada, para que sirva às finalidades do processo: a finalidade jurídica (a atuação da vontade do direito objetivo), mas também social (a pacificação com justiça) e a política (a participação no processo e pelo processo). A terceira onda de que falava Mauro Cappelletti exige um processo civil aderente à realidade social e aos desafios dos novos tempos. O terceiro milênio demanda do processualista uma postura renovada e a
} 
A ausência de consignação, no art. $1^{\circ}$ da Lei de Ação Civil Pública, dos direitos fundamentais sociais, como objeto da ação coletiva, não afasta o cabimento do uso deste instrumento para a respectiva defesa. Aplica-se, in casu, o princípio da não-resistência instrumental à efetivação dos direitos fundamentais sociais. ${ }^{341}$

Desta forma, enquanto constitui dever do Poder Judiciário permitir a abertura da discussão democrática sobre a violação de direitos fundamentais sociais, ${ }^{342}$ ante o conteúdo do princípio da inafastabilidade, o processo coletivo é o único instrumento adequado para esta atividade. ${ }^{343}$

\section{Peculiaridade dos direitos fundamentais sociais enquanto direitos difusos}

É francamente reconhecida a possibilidade de convivência entre os direitos metaindividuais e os direitos individuais, permitindo-se o exercício distinto ou simultâneo do direito de ação. ${ }^{344}$

Entretanto, embora constituam direitos difusos, os direitos fundamentais sociais possuem uma particularidade muito específica, relativa à sua titularidade. Enquanto

coragem de introduzir no ordenamento mudanças não apenas funcionais, mas também estruturais (...) E o novo processo civil demanda um reforço dos poderes do juiz, no qual as reformas brasileiras depositaram sua confiança" (GRINOVER, Ada Pellegrini. Mudanças estruturais no processo civil brasileiro. Revista IOB de Direito Civil e Processual Civil, Porto Alegre, ano 8, n. 44, p. 55, nov./dez. 2006).

${ }^{341}$ Vide supra, Capítulo III, Seção 2.

${ }^{342} \mathrm{O}$ direito à jurisdição, segundo Carlos Roberto Siqueira CASTRO, traduz o direito a um processo constitucional democrático de prestação jurisdicional, isto é, "um conjunto ordenado de atos e procedimentos revestidos de garantias próprias, como o contraditório e a ampla defesa, que induzam à realização formal e substantiva da Justiça pública (...) Bem por isso, a tutela jurisdicional tem de ser prestada com equidade e superioridade ética, a fim de que os litígios se solucionem segundo o sentimento geral da justa arbitragem, sem o que a paz social não ficará devidamente recomposta" (CASTRO, Carlos Roberto Siqueira. A Constituição aberta e os direitos fundamentais: ensaios sobre o constitucionalismo pós-moderno e comunitário. Rio de Janeiro: Forense, 2005. p. 320-356). Dentro desta mesma perspectiva, discorre Dalmo de Abreu DALLARI, afirmando que há um direito fundamental de proteção aos direitos humanos. E, por tal razão, declina o referido autor a tarefa do Poder Judiciário: "Se alguém tiver um direito desrespeitado pode pedir proteção aos juízes e tribunais, seja quem for o culpado pelo desrespeito. Assim, também, quando existir dúvida sobre algum direito, se ele existe ou não, ou a quem ele pertence, é o Poder Judiciário que deve desfazer a dúvida. Para cumprir bem sua tarefa, os juízes devem ter sempre a preocupação de agir com justiça, decidindo sem medo, com serenidade e independência" (DALLARI, Dalmo de Abreu. Direitos humanos e cidadania, cit., p. 96-99).

${ }^{343}$ Oportuna é a observação de Hector Fix ZAMUDIO, sobre a necessidade de se avançar nos estudos para a implementação de instrumentos processuais "sensíveis e breves, que amparem e protejam de maneira eficaz os direitos do homem" (FIX-ZAMUDIO, Hector. La proteccion juridica y procesal de los derechos humanos ante las jurisdicciones nacionales. México: Civitas, 1982. p. 57-59).

${ }^{344}$ Cf. WATANABE, Kazuo. Relação entre demanda coletiva e demandas individuais. Revista de Processo, São Paulo, v. 31, n. 139, p. 28-35, set. 2006; MANCUSO, Rodolfo de Camargo. A concomitância de ações coletivas, entre si, e em face das ações individuais. Revista da Faculdade de Direito da USP, São Paulo, v. 96, p. 371 e s. 2001. 
os titulares de direitos difusos o são, via de regra, igualmente de direitos individuais, relativamente ao mesmo bem da vida, os direitos fundamentais sociais são de titularidade exclusiva da sociedade, e não de seus distintos membros individualmente.

Esta peculiaridade tem reflexos importantíssimos na concepção do processo coletivo, mui especialmente em relação ao provimento jurisdicional a ser produzido.

Os direitos fundamentais sociais foram concebidos para garantir a igualdade substancial de todos os membros da sociedade. ${ }^{345}$ O objetivo da satisfação dos bens da vida protegidos pelos direitos fundamentais sociais é o oferecimento de oportunidades iguais de desenvolvimento a todos os integrantes da sociedade. Logo, estes bens da vida devem ser disponibilizados indistintamente, sem quaisquer privilégios particulares.

Tal situação criou um sério paradoxo, pois, ao se permitir ao cidadão postular individualmente direitos fundamentais sociais, cria-se uma nítida distinção entre os que obtiveram a satisfação da pretensão e os que não a obtiveram. Desta forma, ao conceder direito fundamental social individualmente, o Poder Judiciário está, de forma reflexa, promovendo a desigualdade, porquanto apenas uma parcela mínima dos cidadãos terá garantido o direito postulado.

O paradoxo da desigualdade, portanto, consiste na impossibilidade de se conceder, individualmente, direitos fundamentais sociais, sem a criação de novas formas de discriminação. Por mais que se afigure altruísta a concessão de direitos fundamentais sociais ao cidadão individualmente, tal conduta implica na violação do art. $6^{\circ}$, combinado com o art. $3^{\circ}$, ambos da Constituição Federal.

Se o objetivo do Estado é a igualdade de todos indistintamente e os direitos fundamentais sociais pertencem a toda a sociedade, a concessão destes direitos individualmente representa ruptura do sistema e conduta de certa forma discriminatória, que não contribui para a consolidação da democracia social. ${ }^{346}$

Uma postura do Poder Judiciário que, em princípio, seria ética, acaba contribuindo para a manutenção da igualdade meramente formal dos cidadãos. Esta postura pode servir de anteparo ainda maior para a inação do Estado na satisfação espontânea dos

\footnotetext{
${ }^{345}$ Vide supra, Capítulo I, Seção 7.

${ }^{346}$ Aluisio Gonçalves de Castro MENDES se manifesta sobre o assunto, ao afirmar que as decisões contraditórias proferidas em processos individuais e nas ações coletivas são causa de desigualdade e de insegurança jurídica (MENDES, Aluisio Gonçalves de Castro. Ações coletivas no direito comparado e nacional, cit., p. 37. (Temas atuais de direito processual civil; v. 4). Esta desigualdade é substancialmente destacada no processo coletivo destinado à efetivação dos direitos fundamentais sociais.
} 
direitos fundamentais sociais, na medida em que a sua concessão judicial, de forma pontual, gera uma falsa impressão de que os poderes Legislativo e Executivo estão cumprindo seu papel constitucional. As formas de expressão do poder estatal, por conseguinte, não são efetivamente concitadas à correção e ao realinhamento de suas políticas públicas pelo Poder Judiciário.

Em outras palavras, o conflito é absorvido pelo Poder Judiciário, mas não é resolvido. $^{347}$

A dignidade constitucional da jurisdição não é compatível com subterfúgios desta natureza. ${ }^{348} \mathrm{Na}$ medida em que o problema social é levado ao Poder Judiciário, é imperioso que haja efetiva solução, porque este é o desejo do legislador constituinte, nos termos do que dispõem os arts. $3^{\circ}$ e $6^{\circ}$ da Constituição da República. O problema social, por si só, já é um indicativo de que a democracia corre sério perigo, de forma que, se as demais formas de expressão do poder estatal forem omissas, o Poder Judiciário tem o dever constitucional de corrigir as políticas públicas e realinhá-las de acordo com a melhor solução para o atendimento, com amplitude social, dos bens da vida previstos no art. $6^{\circ}$ da Constituição Federal. ${ }^{349}$

Conclui-se, portanto, que os direitos fundamentais sociais somente poderão ser efetivados através do processo coletivo, com as adaptações necessárias para que o provimento jurisdicional atinja a difusão social dos bens da vida, tal como consignado nos objetivos fundamentais do Estado brasileiro.

Impende consignar, entretanto, que o pressuposto é a ausência ou a deficiência do Estado na prestação do serviço de âmbito social. Caso o serviço seja prestado adequadamente em âmbito social, de forma que esteja plenamente disponível a todos os usuários do sistema, eventual discriminação contra determinadas pessoas, sem qualquer justificativa plausível, poderia gerar violação do princípio da igualdade, previsto no art. $5^{\circ}$,

\footnotetext{
${ }^{347}$ Vide supra, Capítulo II, Seção 7, Subseção 7.

${ }^{348}$ Não podemos olvidar a lição precisa de CHIOVENDA, segundo a qual a jurisdição oferece aos cidadãos a melhor observância das leis, porque não sofre as influências das mutáveis correntes da administração e da política (CHIOVENDA, Giuseppe. Principios de derecho procesal civil. Trad. José Casais y Santaló. Madrid: Reus, 2000. t. 1, p. 388). No caso dos direitos fundamentais sociais, a sua melhor observância circunscreve-se à efetiva garantia da igualdade substancial no âmbito social, através do processo de índole coletiva.

${ }^{349}$ Ernesto Garzón VALDÉS afirma que é função das Cortes supremas a contenção dos "extravios inconstitucionais dos representantes da vontade popular", de forma que o magistrado, neste caso, avalia e controla "a conduta governamental e legislativa de acordo com as pautas constitucionais" (GARZÓN VALDÉS, Ernesto. El papel del poder judicial em la transición a la democracia. In: MALEM, Jorge; OROZCO, Jesús; VÁZQUEZ, Rodolfo (Coords.). La función judicial: ética y democracia. Barcelona: Gedisa, 2003. p. 131).
} 
caput, da Constituição Federal. Neste caso, contudo, não haverá violação de direito fundamental social, porque satisfeito, mas sim do direito individual de igualdade, hipótese que gerará pretensão de caráter individual.

Chegamos aqui ao problema do âmbito de cognição das políticas públicas pelo Poder Judiciário e suas implicações processuais mais evidentes.

\section{5. Âmbito de cognição das políticas públicas pelo Poder Judiciário}

\subsection{Considerações preliminares sobre a análise das políticas públicas em duas fases processuais distintas}

Constituem políticas públicas todos os atos legislativos e administrativos necessários à satisfação espontânea dos direitos fundamentais sociais. Estabelecido o direito fundamental social, os poderes Legislativo e Executivo, no âmbito de suas competências constitucionais, têm o dever de promover a sua irradiação formal e material. Para tanto, a própria Constituição estabelece núcleos constitucionais de irradiação, os quais norteiam a atividade das referidas formas de expressão do poder estatal. ${ }^{350}$

É função precípua do Poder Legislativo e do Poder Executivo levar a efeito as políticas públicas necessárias para a satisfação espontânea dos direitos fundamentais sociais. Por tal razão, gozam estas formas de expressão do poder estatal de ampla liberdade discricionária, mesmo porque são grandes as variáveis lógicas para a irradiação dos direitos fundamentais sociais. Estas variáveis, entretanto, devem sempre observar os parâmetros dos núcleos de irradiação.

O Poder Judiciário tem uma atribuição constitucional residual em matéria de políticas públicas. Isto significa que a jurisdição não pode intervir indistintamente nas políticas públicas desenvolvidas pelos demais poderes. Somente no caso de omissão ou de contrariedade com os núcleos constitucionais de irradiação é que o Poder Judiciário intervém nas políticas públicas.

A intervenção do Poder Judiciário faz-se exclusivamente através do processo coletivo, uma vez que o processo de índole individual pode permitir o paradoxo da

\footnotetext{
${ }^{350}$ Vide supra, Capítulo I, Seções 8 e 9, e Capítulo II, Subseção 7.2.
} 
desigualdade, não promovendo o correto realinhamento de políticas públicas. Mencionado paradoxo poderá, então, causar o desgaste indevido de todas as formas de expressão do poder estatal e a inconstitucionalidade reflexa dos arts. $2^{\circ}, 3^{\circ}$ e $6^{\circ}$ da Constituição Federal. $^{351}$

Proposta a demanda coletiva, que à falta de outra estrutura mais adequada há de ser pelo procedimento da Lei $n^{\circ} 7.347 / 85$, o Poder Judiciário realizará duas espécies de análise das políticas públicas, consoante a especialidade do momento processual. Assim é que análise das políticas públicas será desenvolvida através de dois ângulos diversos: a) políticas públicas que violem direitos fundamentais, na fase de conhecimento, e b) políticas públicas que não atendam ao comando judicial, na fase de cumprimento da sentença.

A distinção é de absoluta relevância, porquanto na fase de conhecimento as políticas públicas serão analisadas exclusivamente sob o ângulo da adequação aos fins constitucionais colimados. Se a finalidade era a satisfação espontânea do direito à saúde, as políticas públicas serão examinadas neste viés e segundo os parâmetros contidos nos núcleos constitucionais de irradiação. As políticas públicas serão estudadas pelo Poder Judiciário, portanto, a partir da adequação dos meios aos fins. Inadequadas, ou omissas, as políticas públicas deverão ser realinhadas e corrigidas através do provimento jurisdicional.

Após o trânsito em julgado da sentença, novos parâmetros deverão ser observados pelo Estado, agora fundamentados no comando judicial. O cumprimento da sentença significa o início da prática dos atos de realinhamento coercitivo das políticas públicas. Desta forma, a análise das políticas públicas far-se-á, agora, sob o prisma dos parâmetros traçados no dispositivo sentencial, posto que completamente esgotada a cognição do juízo.

\subsection{Os direitos fundamentais como o objeto do processo coletivo}

A atividade jurisdicional necessita, para o seu funcionamento, da iniciativa da parte, que busca a satisfação de um bem da vida. Esta pretensão a um bem da vida, segundo Cândido Rangel Dinamarco, constitui o objeto do processo. ${ }^{352}$

\footnotetext{
${ }^{351}$ Vide supra, Capítulo III, Seção 4.

${ }^{352}$ DINAMARCO, Cândido Rangel. Instituições de direito processual civil, cit., v. 2, p. 180. Não se desconhece, também, dentre as inúmeras teorias acerca do assunto, a afirmação de Giuseppe
} 
Os direitos fundamentais sociais protegem os bens da vida descritos no art. $6^{\circ}$ da Constituição Federal. Trata-se de bens soberanos de toda a humanidade, cuja proteção é, segundo o consenso internacional, condição para a erradicação da miséria e de toda forma de poder arbitrário. Além de compromisso ético do Estado brasileiro, a proteção aos direitos fundamentais sociais constitui seu objetivo fundamental, nos termos do que dispõe o art. $3^{\circ}$ da Constituição Federal.

As políticas públicas executadas pelos poderes Legislativo e Executivo vinculam-se à realização dos objetivos fundamentais do Estado, em especial à satisfação espontânea dos bens da vida amparados pelos direitos fundamentais sociais. O Estado está obrigado à satisfação daqueles bens da vida, de forma que as políticas públicas são o veículo apropriado para tanto.

Ocorre que, em determinadas situações, as políticas públicas são omissas ou não efetivam, de forma satisfatória, os direitos fundamentais sociais. Nestas hipóteses ocorre lesão aos direitos fundamentais, o que habilita os seus titulares a apresentarem ao Estado-juiz pretensão ao bem da vida não satisfeito espontaneamente. ${ }^{353}$

Os direitos fundamentais sociais amparam os bens da vida que, por sua dimensão social, constituem grandes temas políticos nacionais, tais como a educação, a saúde, o trabalho, a moradia, o lazer, a segurança, a previdência social, a proteção à maternidade e à infância e a assistência aos desamparados. Pela sua magnitude e essencialidade à vida em sociedade, tais temas já são amplamente discutidos no cenário político brasileiro e objeto de contínuas políticas públicas. Trata-se de demandas naturalmente endereçadas pela sociedade ao corpo político.

Ante às inúmeras políticas públicas que se sucedem para a tentativa de satisfação espontânea dos bens da vida referidos no art. $6^{\circ}$, é natural que o Estado disponibilize parte dos serviços necessários à população. Entretanto, alguns bens da vida fatalmente não serão satisfeitos espontaneamente pelo Estado, o que gerará lesão aos direitos fundamentais sociais.

A pretensão à satisfação coercitiva dos bens da vida inscritos no art. $6^{\circ}$ da Constituição Federal, por conseguinte, constitui o objeto do processo coletivo.

CHIOVENDA, segundo o qual o objeto do processo é a "vontade concreta da lei", conceito que igualmente se adapta à nossa proposição (CHIOVENDA, Giuseppe. Instituzioni di diritto processuale civile: i concetti fondamentali, la dottrina delle azioni, cit., p. 43-44).

${ }^{353}$ Vide supra, Capítulo II, Seção 7, Subseção 2. 
Contudo, dadas as peculiaridades dos direitos fundamentais sociais, não é possível que se formule pretensão individual à satisfação dos bens da vida juridicamente tutelados. ${ }^{354}$ A pretensão aos bens da vida previstos no art. $6^{\circ}$ da Constituição Federal dever ser, invariavelmente, de alcance social, porquanto o provimento jurisdicional produzirá o mesmo resultado. ${ }^{355}$

No processo de índole coletiva, voltado à efetivação dos direitos fundamentais sociais, o pedido deve ser formulado de maneira a permitir que o órgão jurisdicional emita provimento com eficácia social. Não se postula, portanto, direito social individualmente, mas sim coletivamente, objetivando-se a máxima eficácia social do provimento jurisdicional.

O bem da vida educação, exemplificativamente, representa um conceito abstrato, uma meta a ser atingida segundo os parâmetros culturais da sociedade. Não se pode, portanto, pretender que o órgão jurisdicional ordene ao Estado promover educação em nível social. Tal constituiria mera reprodução do comando constitucional genérico, impessoal e abstrato contido no art. $6^{\circ}$ da Constituição Federal. ${ }^{356}$

A jurisdição trabalha com a concreção dos bens da vida tutelados juridicamente. ${ }^{357} \mathrm{O}$ pedido, portanto, deverá permitir a precipitação do bem da vida educação, mediante a propositura de um veículo material que coloque à disposição de toda a sociedade local os meios para se educar. ${ }^{358}$ A construção de uma escola, segundo as necessidades da comunidade envolvida, poderá ser o veículo que disponibilizará o bem da vida educação aos usuários.

\footnotetext{
${ }^{354}$ Vide supra, Capítulo III, Seção 4.

${ }^{355}$ Este raciocínio decorre da aplicação do brocardo sententia debet esse conformis libello (BALDO, L. I, Cod. si plures, 7, 55 ecc), consequência lógica do princípio dispositivo, sintetizado no apotegma ne procedet iudex ex officio (CHIOVENDA, Giuseppe. Saggi di diritto processuale civile. Roma: Società Editrice "Foro Italiano", 1930. p. 157-159). De fato, se o provimento é de alcance social, o pedido deverá ser, igualmente, de alcance social.

${ }^{356}$ Como lembram PINA e LARRAÑAGA, a expressão lex specialis, com a qual se costuma designar a sentença, não implica na criação da norma jurídica pelo magistrado, posto que a atividade jurisdicional destina-se à aplicação do direito existente (PINA, Rafael; CASTILLO LARRAÑAGA, Jose. Instituciones de derecho procesal civil. 10. ed. México: Porrua, 1974. p. 61-62).

${ }^{357}$ Aliás, como ressalta Emilio BETTI, a função do processo civil no ordenamento jurídico é a de promover a atuação da lei por obra da jurisdição, a fim de se possa proteger um concreto interesse (BETTI, Emilio. Diritto processuale civile italiano. 11. ed. Roma: Società Editrice del "Foro Italiano", 1936. p. 1-29).

${ }^{358}$ Nas palavras de Eduardo Juan COUTURE, o pedido "é tão somente a maneira formal de efetivar a ação: é um ato concreto de exercício da ação civil" (COUTURE, Eduardo Juan. Fundamentos do direito processual civil. Trad. Rubens Gomes de Souza. São Paulo: Saraiva, 1946. p. 17). Esta formalidade, entretanto, não poderá ser obstáculo à adequação do pedido para a perfeita manifestação da pretensão ao bem da vida.
} 
O pedido deve permitir ao Poder Judiciário, de forma residual e corretiva, promover a completa irradiação dos direitos fundamentais sociais, de tal sorte que o veículo para a obtenção do bem da vida esteja concretamente à disposição de todos os componentes da sociedade.

Os direitos fundamentais sociais objetivam, essencialmente, garantir a igualdade substancial entre os componentes do grupo social. Pretendem tais direitos, pois, seja eliminada toda e qualquer desigualdade. Desta forma, tanto o pedido como o provimento jurisdicional a ser produzido estão naturalmente dotados de uma necessária plasticidade. ${ }^{359}$

A Constituição estabelece que a atividade criativa para a satisfação espontânea dos direitos fundamentais sociais pertence, prioritariamente, ao Poder Legislativo e ao Poder Executivo. As políticas públicas são a expressão material desta criatividade. Entretanto, no caso de violação dos direitos fundamentais sociais, o Poder Judiciário passará, obrigatoriamente, a realizar esta atividade criativa, sempre em busca da supressão das desigualdades.

Recomenda-se, portanto, que se admita a fungibilidade do veículo para a satisfação dos bens da vida inicialmente proposto no pedido, a fim de que a criatividade possa resultar na melhor solução para o problema. Há que se permitir a adaptação do veículo proposto, mesmo porque a complexidade dos fatos a serem absorvidos no curso do processo poderá exigir solução diversa da inicialmente indicada.

Dentro desta perspectiva, todas as soluções possíveis para a disponibilização dos bens da vida previstos no art. $6^{\circ}$ da Constituição Federal são admissíveis no processo coletivo, desde que objetivem a correção de desigualdades. Ora, se o desiderato dos direitos fundamentais sociais é o de reduzir e eliminar as desigualdades, então é possível, inclusive, a postulação de pretensão ao aprimoramento do serviço já existente, desde que se demonstre a causa originária da desigualdade.

\footnotetext{
${ }^{359}$ Neste sentido, o pensamento de Paulo Henrique dos Santos LUCON, Daniela Monteiro GABBAY, Rafael Francisco ALVES e Tathyana Chaves DE ANDRADE: "Se o bem coletivo é marcado, como ressaltado, pela indisponibilidade, que é, por sua vez, controlada pelo juiz, não faz qualquer sentido restringir a interpretação que este pode fazer do pedido. Seria o mesmo que dizer que o juiz deve anuir com a disposição indevida feita pelo autor. Equivaleria, em última instância, a ratificar um ato contrário à própria lei. Restringir a interpretação do pedido significa, neste sentido, restringir a própria proteção do bem jurídico coletivo a ser tutelado" (LUCON, Paulo Henrique dos Santos; GABBAY, Daniela Monteiro; ALVES, Rafael Francisco; ANDRADE, Tathyana Chaves de. Interpretação do pedido e da causa de pedir nas demandas coletivas (conexão, continência e litispendência). In: LUCON, Paulo Henrique dos Santos (Coord.). Tutela coletiva: 20 anos da Lei da Ação Civil Pública e do Fundo de Defesa de Direitos Difusos, 15 anos do Código de Defesa do Consumidor. São Paulo: Atlas, 2006. p. 189).
} 
Assim, se o município já conta com uma escola que atenda a determinada faixa etária, mas que não possa oferecer os serviços de educação a toda a população local, configura-se hipótese inequívoca de desigualdade, que deverá ser corrigida judicialmente através, por exemplo, da construção de nova escola, ou até mesmo da ampliação daquela já existente.

O critério será sempre o da criatividade para a redução e a supressão da desigualdade social. Daí a enorme plasticidade que se confere ao pedido e ao provimento jurisdicional.

Diante do exposto, concluímos ser indispensável o aperfeiçoamento da legislação, a fim de que se promova a urgente molecularização da relação jurídica processual nas demandas em curso, propostas individualmente para a satisfação coativa dos direitos fundamentais sociais. Necessário, ainda, que se impeça a formulação de pretensão individual de direitos fundamentais sociais, criando-se mecanismos processuais claros acerca dos requisitos do pedido, inclusive no que respeita à fungibilidade respectiva.

As providências in questionis objetivam evitar a ocorrência do paradoxo da desigualdade, mediante a salvaguarda da igualdade substancial e, por consequência, da própria democracia.

Nada impede, segundo nossa proposição, que o magistrado, independentemente da criação das soluções legislativas já apontadas, aperfeiçoe os mecanismos de representatividade adequada nas ações ora em curso e, convocando a parte ideológica - preponderantemente o Ministério Público ou a Defensoria Pública - admita a adequação dos pedidos, de forma a se obter o alcance social do provimento.

A solução em tela é inteiramente compatível com o disposto no art. $3^{\circ}$, combinado com o art. $6^{\circ}$, da Constituição Federal, encontrando fundamento, ainda, no princípio da proibição de resistência instrumental aos direitos fundamentais. ${ }^{360}$

\subsection{O âmbito de cognição das políticas públicas}

O campo de atuação do Poder Judiciário nos processos de índole coletiva, nos quais se busca a satisfação coativa dos direitos fundamentais sociais, é estritamente

\footnotetext{
${ }^{360}$ Vide supra, Capítulo III, Seção 2.
} 
jurisdicional. Desta forma, é a lesão a direito fundamental social que permite o exercício do direito de ação coletiva.

A lesão a direito fundamental social pode operar-se basicamente de duas maneiras. A primeira consiste na omissão completa do Estado na satisfação espontânea dos direitos constitucionais subjetivos ${ }^{361}$ previstos no art. $6^{\circ}$ da Constituição Federal. A segunda forma de lesão a direitos fundamentais sociais decorre do comportamento, comissivo ou omissivo, do Estado, que permite a ocorrência de desigualdade social na fruição dos serviços criados para a satisfação espontânea dos bens da vida referidos no art. $6^{\circ}$ da Constituição Federal.

Pode-se, portanto, sintetizar o fato a ser narrado na petição inicial como a demonstração da conduta do Estado que cause a impossibilidade de fruição, ou mesmo a desigualdade social na fruição, dos bens da vida discriminados no art. $6^{\circ}$ da Constituição Federal. Há que se demonstrar, pois, que a conduta do Estado gera desigualdade social.

Evidentemente, o fundamento jurídico do pedido é extraído do já referido art. $6^{\circ}$ da Constituição Federal.

Se não há disponibilização de veículo de fruição do bem da vida, encontra-se violado o direito fundamental social. Da mesma forma, a disponibilização de veículo que, por suas deficiências, gere desigualdade social constitui violação e, portanto, lesão a direito fundamental social.

As políticas públicas integram a causa de pedir, posto que representam a conduta do Estado, seja comissiva ou omissivamente. $\mathrm{O}$ fato, ao descrever a lesão a direito fundamental social, igualmente se refere ao comportamento do Estado e, portanto, deve fazer menção às políticas públicas realizadas ou sequer iniciadas.

Conclui-se, por conseguinte, que o fato narrado na petição inicial deverá demonstrar uma correspondência lógica entre as políticas públicas desenvolvidas, ou não, pelo Estado e a lesão causada ao direito fundamental postulado. Esta lesão, como visto, estará vinculada ao critério de desigualdade social.

\footnotetext{
${ }^{361}$ Quiroga LAVIÉ explica que os direitos subjetivos públicos devem ser interpretados como instrumentos de participação social, assim se expressando sobre o direito de ação: "Em suas origens para justificar a defesa dos interesses estamentais, logo para imprimir a defesa dos direitos cidadãos, hoje o vermelho dos direitos públicos subjetivos pugna pela defesa dos direitos sociais de todos aqueles que conformam o anônimo e despossuído ser da massa social e dos que precisam 'aceder à justiça' e carecem dos respectivos recursos" (LAVIÉ, Quiroga. Los derechos públicos subjetivos y la participación social. Buenos Aires: Depalma, 1985. p. 1).
} 
Ao mesmo tempo em que as políticas públicas deverão compor a causa de pedir, poderão constituir exceção substancial direta. Isto porque o Estado, ao exercitar a sua defesa, tenderá a comprovar que realizou, efetivamente, todas as políticas públicas necessárias para a fruição dos bens da vida amparados pelos direitos fundamentais sociais. Caso comprovada a alegação, fatalmente o pedido será julgado improcedente.

Note-se que cumpre ao Estado comprovar que o veículo de fruição do bem da vida encontra-se à disposição de todos os integrantes da sociedade, ou que as especificidades do veículo não geram qualquer desigualdade social.

Resulta evidenciado, por conseguinte, que toda a cognição do juízo girará em torno da ocorrência, ou não, de desigualdade social. Esta desigualdade deve ser aferida no caso concreto, mediante a análise da possibilidade de fruição dos bens da vida amparados pelo art. $6^{\circ}$ da Constituição Federal.

Não se trata, evidentemente, da discussão acerca da desigualdade social em termos genéricos, porque tal contrariaria a própria natureza da jurisdição. O que se discute no caso concreto é a eventual desigualdade social gerada pela ausência de satisfação espontânea e adequada do bem da vida indicado no pedido.

No âmbito de cognição do órgão jurisdicional, haverá casos nos quais a lesão a direito fundamental será facilmente detectada. Um conjunto mínimo de provas poderá levar o magistrado à conclusão de que o Estado não disponibilizou veículo algum para a fruição do bem da vida amparado por direito fundamental social. Entretanto, em outros casos, a cognição do juízo decorrerá de atividade muito mais complexa.

Figure-se hipótese na qual o Município alegue em juízo que já tomou todas as providências para a construção de uma escola de ensino fundamental, mas ainda não recebeu determinada subvenção do Estado, indispensável para a realização da obra. Não há dúvida de que o direito fundamental social foi violado, de forma que o pedido há de ser julgado procedente. Entretanto, imprescindível que se estabeleça qual o ente público a ser responsabilizado.

Para a solução da questão, o magistrado deverá utilizar-se dos núcleos constitucionais de irradiação. ${ }^{362}$ Através da análise do núcleo de irradiação contido na Seção I, do Capítulo III, do Título VIII, da Constituição Federal, o julgador poderá reconstruir toda a cadeia lógica de ramificações normativas ao nível subconstitucional, até

\footnotetext{
${ }^{362}$ Vide supra, Capítulo I, Seções 8 e 9.
} 
chegar à imputação de responsabilidade. Devem ser analisados todos os atos logicamente concatenados, a partir do núcleo constitucional de irradiação até a inauguração da escola de ensino fundamental.

Os núcleos constitucionais de irradiação, portanto, atuam como recurso para a análise de constitucionalidade e de adequação das políticas públicas no processo de conhecimento.

Mas há ainda uma outra questão fundamental, referente ao tempo para a realização das políticas públicas.

Inicialmente, impõe-se a consignação de que a simples comprovação de lesão a direito fundamental social já importa no julgamento de procedência do pedido na ação coletiva. Entretanto, existe uma especificidade a ser considerada na análise do tempo exigível para a realização concreta do veículo de satisfação dos bens da vida amparados pelos direitos fundamentais.

Constituindo os núcleos de irradiação programas a serem executados pelo Estado, é natural que a sua realização se projete no tempo, daí o sentido da expressão normas programáticas. ${ }^{363}$ As políticas públicas, portanto, lastreiam-se ordinariamente em normas de conteúdo programático, ou seja, de execução diferida no tempo.

Imagine-se a hipótese na qual o Estado, no exercício do contraditório, alegue que já promoveu todas as políticas públicas necessárias para a construção da escola de ensino fundamental, de tal forma que, segundo as expectativas, os usuários poderão se beneficiar concretamente do serviço público em até um ano. Mesmo neste caso, o pedido deverá ser julgado procedente, pois a lesão ao direito fundamental social foi comprovada.

Como os direitos fundamentais são de eficácia plena e imediata, o tempo não é fator impeditivo para a concessão do provimento; ao contrário, indica inequívoca violação do direito. Ocorre que a própria sentença terá, inúmeras vezes, um conteúdo igualmente programático, no sentido de estabelecer um interlúdio específico para a disponibilização do veículo que permita a satisfação do bem da vida.

Então é razoável que o magistrado, após analisar as cadeias de ramificação das políticas públicas, a partir dos núcleos constitucionais de irradiação, acomode o provimento jurisdicional, estabelecendo prazo para que se concretize a efetiva

\footnotetext{
${ }^{363}$ Vide supra, Capítulo I, Seção 10.
} 
disponibilização do serviço. O magistrado, ao passo em que julga procedente o pedido, fixa termo para a disponibilização do serviço público, consoante a razoabilidade exigida no caso concreto, constituindo este o provimento jurisdicional que posteriormente vinculará a conduta do Estado.

As normas programáticas, portanto, embora não exerçam qualquer influência sobre a configuração da lesão aos direitos fundamentais sociais, encontram-se dentro do campo de cognição do magistrado, a fim de que se possa produzir o provimento jurisdicional mais adequado para a redução ou supressão da desigualdade. As vicissitudes do caso concreto é que vão orientar o ajuste do tempo na prestação jurisdicional, sempre sobre o crivo do critério da razoabilidade.

Pode-se afirmar, portanto, que a cognição das políticas públicas no processo coletivo, no plano vertical, é plena e exauriente. ${ }^{364}$

\subsection{Características distintivas do provimento jurisdicional}

O provimento jurisdicional, no processo coletivo destinado à efetivação dos direitos fundamentais sociais, possui como característica principal a sua plasticidade. E tal se justifica, pois o exercício da atividade jurisdicional há de determinar, após o necessário discurso justificativo, ${ }^{365}$ a melhor solução para a redução ou supressão da desigualdade no oferecimento de serviços destinados à satisfação dos direitos fundamentais sociais.

Muitas vezes, a parte, ao apresentar sua pretensão ao bem da vida, poderá propor uma solução que não se mostre adequada aos fins colimados, ou que, mesmo se mostrando adequada, revele-se inapta após o exame das políticas públicas já desenvolvidas.

Estas as razões que recomendam a plasticidade, ou possibilidade de adaptação, do provimento jurisdicional, uma vez que, essencialmente, o Poder Judiciário estará colmatando a conduta omissiva dos entes públicos, em atendimento ao disposto nos arts. $3^{\circ}$

\footnotetext{
${ }^{364}$ WATANABE, Kazuo. Da cognição no processo civil, cit. p. 81 e s.

${ }^{365}$ Este é o sentido que Michele TARUFFO empresta, a nosso ver com razão, à motivação da sentença (TARUFFO, Michele. La motivazione della sentenza civile. Padova: CEDAM, 1975. p. 107-149). Aliás, como bem pontuam ANDOLINA e VIGNERA, o "dever constitucional da motivação é condição mínima de efetividade do princípio da legalidade da atividade jurisdicional" (ANDOLINA, Italo; VIGNERA, Giuseppe. Il modello costituzionale del processo civile italiano: corso di lezione. Torino: G. Giappichelli, 1990. p. 181-186).
} 
e $6^{\circ}$ da Constituição Federal. A atividade do órgão jurisdicional, pois, reflete a própria vontade criativa do Estado, de forma que deve lastrear-se no postulado de máxima eficiência.

A atividade jurisdicional colmata os atos omissivos do Estado, vencendo etapas na cadeia lógico-consequencial que se desdobrariam, em tese, desde os núcleos constitucionais de proteção até o oferecimento do serviço público. O provimento jurisdicional, portanto, deverá servir de ponte de ligação entre o bem da vida constitucionalmente tutelado e a disponibilização respectiva a todos os componentes do grupo social.

Neste aspecto, é imprescindível que a atividade jurisdicional promova saltos suficientes na cadeia lógico-consequencial para assegurar a futura exequibilidade do julgado. ${ }^{366}$ Assim, exemplificativamente, se a pretensão é relativa à satisfação da educação fundamental, e o veículo indicado é a construção de uma escola, então o dispositivo sentencial deverá ser o mais preciso possível, a fim de que restem poucos atos de materialização a serem ultimados, não se permitindo novas delongas previsíveis na cadeia lógico-consequencial, tais como eventuais deliberações legislativas e executivas de alto conteúdo discricionário.

Há, contudo, outra característica distintiva do provimento jurisdicional prolatado no processo coletivo destinado à efetivação dos direitos fundamentais sociais.

Sabe-se que a atividade do Poder Judiciário é de realinhamento, ou correção, das políticas públicas desenvolvidas, ou omitidas, pelas demais formas de expressão do poder estatal. Trata-se de atividade residual, uma vez que cumpre prioritariamente aos poderes Legislativo e Executivo a execução das políticas públicas necessárias para a satisfação espontânea dos direitos fundamentais sociais.

Na medida em que o órgão jurisdicional prolata uma sentença, realinhando, em seu dispositivo, as políticas públicas, as demais formas de expressão do poder estatal vinculam-se à sua consecução. Ocorre que a solução encontrada pelo Poder Judiciário

\footnotetext{
${ }^{366}$ Como observa Italo ANDOLINA, o "controle cognitivo sucessivo da formação do título executivo" objetiva garantir uma exata correspondência entre a representação e a realidade do crédito executivamente realizável, mediante a clara delimitação do seu âmbito de abrangência (ANDOLINA, Italo. "Cognizione" ed "esecuzione forzata” nel sistema della tutela giurisdizionale. Milano: Giuffrè, 1983. p. 101-136). Sobre a execução forçada e suas implicações, cf., ainda, CONIGLIO, Antonino. Osservazioni al Progetto Preliminare del Codice di Procedura Civile. Milano: Giuffrè, 1938. Sobre a problemática da execução das medidas judiciais contra omissões do Poder Público, cf. ainda, SALLES, Carlos Alberto de. Ação civil pública contra omissões do poder público: limites e possibilidades. In: interesse público: o processo como instrumento de defesa social, cit., p. 211 e s. (Org.). Processo civil de
} 
poderá se tornar obsoleta ou mesmo inconveniente, no tempo, face à eventual proposta de execução de políticas públicas mais aprimoradas pelo Estado.

Ora, se o Estado apresentar solução mais efetiva do que aquela determinada na decisão judicial transitada em julgado, não estará autorizado a realizá-la, face ao reconhecimento da coisa julgada material?

Esta se nos afigura uma hipótese clara de relativização da coisa julgada. Com efeito, se o objetivo do Estado é a consecução do bem comum, na esteira do que dispõe o art. $3^{\circ}$ da Constituição Federal, então esta finalidade estará sendo atendida ao se aprimorarem os meios de satisfação dos bens da vida amparados pelos direitos fundamentais sociais. Há, in casu, uma clara contraposição entre princípios de grandeza constitucional, tanto assim considerados a coisa julgada e os objetivos fundamentais do Estado. O critério de proporcionalidade, neste passo, certamente recomenda seja assegurado este último em detrimento do primeiro.

\subsection{Análise do princípio da proporcionalidade em matéria de direitos fundamentais sociais}

A correta aplicação do princípio da proporcionalidade, no processo de índole coletiva destinado à efetivação dos direitos fundamentais sociais, exige a análise de uma das características mais importantes destes direitos, a sua essencialidade. ${ }^{367}$

Todos os direitos fundamentais são essenciais, não importando a geração na qual seja doutrinariamente catalogado. Todos fazem parte da condição humana, de forma que não podem dela ser desvinculados.

Por outro lado, é a reunião de todos os direitos fundamentais que compõe a dignidade do ser humano. Não se pode falar, portanto, de escolhas proporcionais em matéria de concessão judicial de direitos fundamentais. Desde que assegurados pela Constituição Federal, os direitos fundamentais formam uma integralidade que define a dignidade humana. A proteção do Estado, portanto, deve recair sobre a totalidade destes direitos.

\footnotetext{
${ }^{367}$ Vide supra, Capítulo I, Seção 5.
} 
Não cabe ao Estado optar sobre a concessão alternativa do direito à educação ou do direito à saúde, exemplificativamente. Tal escolha representaria a admissão de que os direitos humanos podem ser arbitrariamente suprimidos pelo Estado, opção frontalmente contrária à democracia e alinhada com a ideologia totalitária.

Nesta linha de pensamento, o Poder Judiciário não está autorizado, na análise dos pedidos formulados, a decidir se um direito fundamental é, ou não, essencial, julgando, com base em tal fundamento, improcedente o pedido ou mesmo extinguindo o processo sem julgamento do mérito. Não há, em outras palavras, margem de escolha para o Estado e tampouco para o órgão jurisdicional.

Entretanto, o princípio da proporcionalidade poderá ser utilizado nas hipóteses em que se permita a exequibilidade imediata da decisão. Neste caso, a força coativa do Estado-juiz irá intervir diretamente no orçamento do ente público, de tal forma que, ausente capacidade financeira para o atendimento de todas as decisões judiciais, ter-se-á que escolher quais os bens da vida serão mais prontamente atendidos.

Tal lógica se aplica tanto ao cumprimento da sentença, como às tutelas de urgência. Neste último caso, é imprescindível que o Poder Judiciário tenha especial cautela na concessão de liminares, porquanto a intervenção generalizada no orçamento, sem o esgotamento necessário da cognição e a análise consistente de proporcionalidade, poderá engessar outras políticas públicas igualmente importantes para a satisfação, em conjunto, dos direitos fundamentais.

O pressuposto, portanto, é o de se garantir, na medida das possibilidades, uma harmonia do Estado na satisfação conjunta dos direitos fundamentais sociais, evitando-se a supressão de alguns bens da vida em detrimento de outros. Daí porque, salvo em casos de indiscutível urgência, é recomendável que se postergue a exequibilidade do julgado para a fase de cumprimento de sentença, a sua via natural. 


\section{CONCLUSÕES}

Ao longo de toda a exposição, inúmeras afirmações foram realizadas, a fim de que se pudesse construir uma hipótese viável de solução para o problema proposto, a partir de uma linha clara de instrumentalismo substancial do processo. O nosso objetivo foi o de, unicamente, provocar a transição de pensamento para a abertura completa do sistema à proteção jurisdicional dos direitos fundamentais de segunda e outras gerações.

Algumas conclusões gerais, decorrentes da sistematização proposta, devem ser inicialmente destacadas: a) os direitos fundamentais sociais possuem plena e imediata eficácia, não se confundindo com os núcleos constitucionais de irradiação; b) o Poder Judiciário, como poder político, tem o dever constitucional e o compromisso ético de apreciar as demandas que envolvam lesão a direitos fundamentais sociais; c) o instrumento adequado para a efetivação dos direitos fundamentais sociais é o processo de índole coletiva; d) o objeto do processo coletivo é a pretensão ao bem da vida amparado pelos direitos fundamentais sociais; e) o Poder Judiciário exerce cognição plena e exauriente das políticas públicas; f) o provimento jurisdicional comporta todas as soluções adequadas ao realinhamento das políticas públicas, desde que pautado pelo princípio da igualdade substancial.

Outras assertivas foram lançadas, em caráter conclusivo, constituindo referencial para as conclusões básicas. Destacamos as seguintes:

1. Após a Segunda Grande Guerra Mundial, os direitos humanos passaram por uma completa renovação ética, com o propósito de impedir o retorno do arbítrio no exercício do poder. Este novo sistema ético de referência implicou na proteção irrestrita dos direitos individuais (v. Capítulo I, Seções 1 e 2).

2. Por meio de sua positivação, os direitos humanos são institucionalizados, o que lhes confere dignidade constitucional, permitindo a sua proteção jurisdicional no âmbito interno dos Estados (v. Capítulo I, Seção 3).

3. Embora com feições próprias, os direitos fundamentais constituem direitos subjetivos constitucionais, produzindo plena irradiação formal e material. São, portanto, exigíveis do Estado (v. Capítulo I, Seção 4). 
4. Dentre as relevantes características dos direitos fundamentais, indispensáveis para a sua correta tutela jurisdicional, destacam-se a universalidade, a prioridade, a essencialidade e a integralidade (v. Capítulo I, Seção 5).

5. A internacionalização dos direitos fundamentais criou um sistema aberto e em constante renovação, de forma que o acréscimo contínuo de novos direitos fundamentais é o seu pressuposto basilar. O Brasil vinculou-se, voluntariamente, a esse sistema e, portanto, igualmente deve adotar o sistema ético de referência, permitindo a constante renovação do seu subsistema (v. Capítulo I, Seção 6).

6. A segunda geração de direitos fundamentais foi concebida para a consecução da igualdade substancial, de forma a fortalecer a democracia social (v. Capítulo I, Seção 7).

7. A análise da morfologia dos direitos fundamentais sociais destaca a existência de duas entidades distintas: os direitos fundamentais, propriamente ditos, e os núcleos constitucionais de irradiação. Os núcleos constitucionais de irradiação constituem o parâmetro normativo para o desenvolvimento das políticas públicas pelo Estado (v. Capítulo I, Seção 8).

8. As políticas públicas, irradiadas através dos núcleos constitucionais, representam a satisfação espontânea dos direitos fundamentais sociais pelo Estado. Tratase do adimplemento voluntário da obrigação constitucional pelo Estado (v. Capítulo I, Seção 9).

9. A eficácia plena e imediata dos direitos fundamentais sociais decorre de sua abordagem sistêmica, a partir das implicações do sistema ético de referência (v. Capítulo I, Seção 10).

10. Montesquieu concebeu a teoria da separação de poderes em um momento histórico no qual se objetivava a contenção do poder pelo poder. Sua linha de abordagem continha um viés fundamentalmente liberal (v. Capítulo II, Seção 1).

11. A transição do Estado liberal para o Estado social importou em profunda alteração da concepção da teoria da separação dos poderes. O Estado assume compromissos de realização social e vincula as formas de expressão de seu poder à consecução de seus fins (v. Capítulo II, Seção 2). 
12. A assunção do controle de constitucionalidade pelo Poder Judiciário o elevou ao patamar de poder político, representando o início da discussão acerca da “judicialização da política” (v. Capítulo II, Seção 3).

13. O Estado, para atender às suas finalidades, destacadamente a efetivação dos direitos humanos sociais, dotou a Constituição de programas a serem atingidos. Essa constitucionalização de programas de ação do Estado dificultou a atividade jurisdicional, na medida em que se criou o conceito de normas programáticas (v. Capítulo II, Seção 4).

14. A inadimplência do Estado, relativamente aos direitos fundamentais sociais, implica em lesão desses direitos e, por conseguinte, gera a possibilidade de exigência imediata dos bens da vida constitucionalmente tutelados por intermédio da atividade jurisdicional (v. Capítulo II, Seção 5).

15. $\mathrm{O}$ art. $2^{\circ}$ da Constituição Federal deve ser interpretado à luz dos respectivos arts. $3^{\circ}$ e $5^{\circ}$, inciso XXXV. Deste modo, o Poder Judiciário, durante o exercício do controle de constitucionalidade, deve examinar a compatibilidade dos atos praticados pelas demais formas de expressão do poder estatal a partir de sua conformidade com os objetivos do Estado. O desvio destes objetivos, que impliquem em lesão aos direitos fundamentais sociais, permite o exercício do direito ação (v. Capítulo II, Seção 6).

16. O Poder Judiciário, por ser uma das formas de expressão do poder estatal e estar vinculado ao comando contido no art. $3^{\circ}$ da Constituição Federal, deve adotar o sistema ético de referência. A efetivação dos direitos fundamentais sociais, portanto, deve ser seu compromisso ético de maior relevância (v. Capítulo II, Subseção 7.1).

17. O âmbito de atuação do Poder Judiciário circunscreve-se à análise da existência de lesão, ou violação, aos direitos fundamentais sociais. Configurada a lesão, consistente no inadimplemento do bem da vida, deve o Poder Judiciário prestar jurisdição, vinculando o Estado à consecução destes bens (v. Capítulo II, Subseção 7.2).

18. O princípio da separação de poderes não pode ser invocado para a nãoefetivação dos direitos fundamentais sociais, porque $\mathrm{o}$ Poder Judiciário atua exclusivamente através da jurisdição e, portanto, não invade a esfera de competência constitucional dos demais poderes (v. Capítulo II, Subseção 7.3).

19. A independência do Poder Judiciário e a imparcialidade do órgão jurisdicional são requisitos indispensáveis para a proteção da democracia. A independência 
e a imparcialidade são alcançadas na medida em que os magistrados vinculam-se, exclusivamente, à política estatal, e não à política partidária (v. Capítulo II, Subseção 7.4).

20. Os juízes detêm legitimidade democrática para a efetivação dos direitos fundamentais sociais. Esta legitimidade decorre da própria independência necessária para cumprir as finalidades do Estado. Como as demais formas de expressão do poder estatal estão sob a jurisdição do Poder Judiciário, devem os seus membros resguardarem-se completamente de qualquer ligação político-partidária (v. Capítulo II, Subseção 7.5).

21. A mesma independência do Poder Judiciário impede que sejam absorvidos conceitos externos à jurisdição para o embaraço da análise judicial da violação dos direitos fundamentais sociais. O orçamento deve ser visto como o patrimônio do Estado e sua destinação prioritária é o atendimento dos direitos fundamentais sociais (v. Capítulo II, Subseção 7.6).

22. Um dos maiores perigos à efetivação dos direitos fundamentais sociais e à democracia social é a autoneutralização do Poder Judiciário. Isto porque cabe somente a esta forma de expressão do poder estatal avaliar qual o âmbito de atuação da jurisdição (v. Capítulo II, Subseção 7.7).

23. Constituem desafios do Poder Judiciário, no século XXI, a tradução jurídica das questões político-institucionais, a preservação do princípio da separação de poderes, a promoção da completa efetivação dos direitos fundamentais sociais e a manutenção a unidade do sistema (v. Capítulo II, Subseção 7.8).

24. Durante a evolução do processo coletivo, os direitos fundamentais sociais foram desconsiderados, ante a desconexão observada entre o direito constitucional e o direito processual. A institucionalização dos direitos fundamentais sociais não foi captada para a compreensão integral dos interesses e direitos difusos (v. Capítulo III, Seção 1).

25. Como um dos objetivos essenciais do Estado, nos termos do art. $3^{\circ}$ da Constituição Federal, é a efetivação dos direitos fundamentais sociais, a sua violação deve ser obrigatoriamente examinada pelo Poder Judiciário, ex vi do disposto no respectivo art. $5^{\circ}$, inciso XXXV. O Poder Judiciário, portanto, tem o dever constitucional e o compromisso ético de avaliar a violação dos direitos fundamentais sociais e de corrigir as políticas públicas levadas a efeito em desacordo com os fins do Estado (v. Capítulo III, Seção 2). 
26. O processo coletivo é o instrumento adequado à efetivação dos direitos fundamentais sociais, dado a sua inequívoca natureza difusa (v. Capítulo III, Seção 3).

27. Os direitos fundamentais previstos no art. $6^{\circ}$ da Constituição Federal são de titularidade de toda a sociedade. Logo, não é possível, em regra, a sua concessão de forma individualizada, sob pena de se causar um paradoxo de desigualdade (v. Capítulo III, Seção 4).

28. As políticas públicas devem ser analisadas em duas fases distintas do processo: a) políticas públicas que violem direitos fundamentais, na fase de conhecimento, e b) políticas públicas que não atendam ao comando judicial, na fase de cumprimento da sentença (v. Capítulo III, Subseção 5.1).

29. A pretensão aos bens da vida amparados pelos direitos fundamentais sociais constitui o objeto do processo coletivo. O pedido a ser formulado no processo coletivo deve estar sujeito a fungibilidade, a fim de que o veículo para a satisfação dos bens da vida tenha o maior alcance social possível (v. Capítulo III, Subseção 5.2).

30. As políticas públicas integram a causa de pedir remota do processo coletivo, podendo constituir exceção substancial direta. A cognição sobre as políticas públicas será plena e exauriente (v. Capítulo III, Subseção 5.3).

31. O provimento jurisdicional deverá ser dotado de plasticidade, com o propósito de que o veículo criado para a satisfação dos bens da vida tenha o máximo alcance social. Por outro lado, na hipótese de o Estado propor, durante o cumprimento da sentença, a consecução de veículo mais aperfeiçoado do que o concebido na sentença ou acórdão, deve-se permitir a relativização da coisa julgada, a fim que não colida com o art. $3^{\circ}$ da Constituição Federal (v. Capítulo III, Subseção 5.4).

32. Dado que os direitos fundamentais constituem uma integralidade, não é possível ao Poder Judiciário exercitar qualquer escolha para a sua concessão. Tal somente será possível na hipótese de insuficiência de recursos do Estado, na fase de cumprimento de sentença ou nos casos de concessão de liminar em tutelas de urgência (v. Capítulo III, Seção 5.5). 


\section{REFERÊNCIAS BIBLIOGRÁFICAS}

ABRAMOVICH, Victor; COURTIS, Christina. Los derechos sociales como derechos exigibles. Madrid: Trotta, 2002.

ALCALÁ-ZAMORA Y CASTILLO, Niceto. Proceso, autocomposición y autodefensa. 2. ed. México: UNAM, 1970.

ALEXANDRINO, José de Melo. Direitos fundamentais: introdução geral. Estoril: Princípia, 2007.

ALEXY, Robert. Teoria de los derechos fundamentales. Trad. Ernesto Garzón Valdés. Madrid: Centro de Estudios Constitucionales, 1997.

ALlORIO, Enrico. Commentario del Codice di Procedura Civile: Art. 1-68. Torino: Unione Tipografico-Editrice Torinese, 1973. Livro 1, t. 1.

ALMEIDA JUNIOR, João Mendes de. Direito judiciario brazileiro. Rio de Janeiro: Typografia Baptista de Souza, 1918.

Programa do Curso Judiciário leccionado na Faculdade de Direito de S. Paulo.

São Paulo: Typ. Hennies Irmãos, 1910.

ALONSO JUNIOR, Hamilton. A ampliação do objeto das ações civis públicas na implementação dos direitos fundamentais. In: MILARÉ, Édis (Coord). Ação civil pública após 20 anos: efetividade e desafios. São Paulo: Ed. Revista dos Tribunais, 2005.

ALVIM, Arruda. Manual de direito processual civil. 7. ed. São Paulo: Ed. Revista dos Tribunais, 2001. v. 1.

ANDOLINA, Italo. "Cognizione" ed "esecuzione forzata" nel sistema della tutela giurisdizionale. Milano: Giuffrè, 1983.

; VIGNERA, Giuseppe. Il modello costituzionale del processo civile italiano: corso

di lezione. Torino: G. Giappichelli, 1990.

ANDRADE, José Carlos Vieira de. Os direitos fundamentais na Constituição Portuguesa de 1976. 3. ed. Coimbra: Almedina, 2006.

ARISTÓTELES. Política. 5. ed. São Paulo: Martin Claret, 2008. (Coleção a Obra-Prima de Cada Autor).

ARON, Raymond. As etapas do pensamento social. São Paulo: Martins Fontes, 2002. 
ARRETCH, Marta. Emergência e desenvolvimento do Welfare State: teorias explicativas. BID, Rio de Janeiro, n. 39, 1995.

ATTARDI, Aldo. L'interesse ad agire. Padova: CEDAM, 1958.

AUDARD, Catherine. O princípio de legitimidade democrática e o debate RawlsHabermas. In: ROCHLITZ, Rainer (Coord.). Habermas: o uso público da razão. Rio de Janeiro: Tempo Brasileiro, 2005.

BARBA, Stefano. Il Codice di Procedura Civile del Regno D'Italia: illustrato com tutte le monografie, annotazioni critiche, pere, circolari ministeriali e cc. Pubblicate dal 1866 ad oggi e disposte sistematicamente sotto i relativi e singoli articoli cui tendono ad illustrare. Milano: Casa Editrice Dottor Francesco Vallardi, 1898.

BARRET-KRIEGEL. Blandine. Les drois de l'homme et le droit naturel. Paris: PUF, 1989.

BARROSO, Luís Roberto. Curso de direito constitucional contemporâneo: os conceitos fundamentais e a construção do novo modelo. São Paulo: Saraiva, 2009.

BASTOS, Aurélio Wander Chaves. Conflitos sociais e limites do Poder Judiciário. Rio de Janeiro: Eldorado Tijuca, 1975.

BAUSOLA, Adriano. Il fondamento dei diritti umani. In: LIPPOLIS, Laura (Coord.). Diritti umani, poteri degli Stati e tutela dell'ambiente. Milano: Giuffrè, 1993.

BEDAQUE, José Roberto dos Santos. Direito e processo: influência do direito material sobre o processo. 2. ed. 2. tir. São Paulo: Malheiros Ed., 2001.

BERGALLI, Roberto. Estado democrático y cuestión judicial: vias para alcanzar una auténtica y democrática independencia judicial. Buenos Aires: Depalma, 1984.

BERLE, Adolf A. The three faces of power. New York: Harcourt; Brace \& World, 1967.

BETTI, Emilio. Diritto processuale civile italiano. 11. ed. Roma: Società Editrice del "Foro Italiano", 1936.

BHAGAVAD-GÎTÂ. A mensagem do mestre. Trad. Francisco Valdomiro Lorenz. São Paulo: Pensamento, 1993.

BODIGUEL, Jean-Luc. Les magistrats: un corps sans ame? Paris: Puf, 1991.

BONAUDI, Emilio. La tutela degli interessi collettivi. Milano: Fratelli Bocca, 1911.

BONAVIDES, Paulo. Curso de direito constitucional. 13. ed. São Paulo: Malheiros Ed., 2003. 
BONAVIDES, Paulo. Do Estado liberal ao Estado social. 4. ed. Rio de Janeiro: Forense, 1980.

BOVERO, Michelangelo. Derechos fundamentales y democracia em La teoria de Ferrajoli: un acuerdo global y una discrepancia concreta. In: FERRAJOLI, Luigi; BACCELLI, Luca; BOVERO, Michelangelo; GUASTINI, Riccardo; JORI, Mario; PINTORE, Anna; VITALE, Ermano; ZOLO, Danilo. Derechos fundamentales y democracia en Ferrajoli. 3. ed. Madrid: Trotta, 2007.

BRANDÃO, Adelino. Os direitos humanos: antologia de textos históricos. São Paulo: Landy, 2001.

BUCCI, Maria Paula Dallari. O conceito de política pública em direito. In: (Org.). Políticas públicas: reflexões sobre o conceito jurídico. São Paulo: Saraiva, 2006.

BUERGENTHAL, Thomas; NORRIS, Robert; SHELTON, Dinah. Protecting human rights in the americas: selected problems. 2. ed. Arlington: Engel, 1986. 389 p.

CALAMANDREI, Piero. Instituciones de derecho procesal civil: segun el nuevo código. Trad. Santiago Sentís Melendo. Buenos Aires: Ediciones Juridicas Europa-America, 1973. v. 2 .

Potere Giudiziario e Suprema Corte Costituzionale. Appendici - I Projetti di Riforma. In: RIGANO, Francesco. Costituzione e potere giudiziario: ricerca sulla formazione delle norme costituzionali. Padova: Cedam, 1982.

CAMPBELL, Tom; GOLDSWORTHY, Jeffrey; STONE, Adriene. Protecting human rights: instruments and institutions. Oxford: Oxford University Press, 2005.

CANARIS, Claus-Wilhelm. Pensamento sistemático e conceito de sistema na ciência do direito. 3. ed. Lisboa: Fundação Calouste Gulbenkian, 2002.

CANOTILHO, José Joaquim Gomes. Constituição dirigente e vinculação do legislador: contributo para a compreensão das normas constitucionais Programáticas. Coimbra: Coimbra Ed., 1994.

Direito constitucional. 6. ed. Coimbra: Almedina, 1993.

; MOREIRA, Vital. Constituição da República Portuguesa anotada. 4. ed. Coimbra: Coimbra Ed., 1978. v. 1.

CAPOGRASSI, Giuseppe. Dichiarazione Universale dei Diritti dell'Uomo: Convenzione per la Proscrizione del Genocidio. Padova: CEDAM, 1950. 
CAPPELLETTI, Mauro. O controle judicial de constitucionalidade das leis no direito comparado. Trad. Aroldo Plínio Gonçalves, com revisão de José Carlos Barbosa Moreira. Porto Alegre: Sergio Antonio Fabris, 1984.

- Formações sociais e interesses coletivos diante da Justiça Civil. São Paulo. Separata da Revista de Processo, São Paulo, n. 105, p. 128-159, 1977.

. Juízes legisladores? Trad. Carlos Alberto Alvaro de Oliveira. Porto Alegre: Sergio Antonio Fabris, 1993.

; GARTH, Bryant. Acess to justice: a world survey. Milano: Giuffrè, 1978. v. 1.

; TALLON, Denis. Fundamental guarantees of the parties in civil litigation. Milano: Giuffrè, 1973.

CARDIA, Carlo. Genesi dei diritti umani. 2. ed. Torino: G. Giappichelli, 2005.

CARNELUTTI, Francesco. Dirito e processo. Napoli: Morano, 1958.

CARPI, Frederico; TARUFFO, Michele; COLESANTI, Vittorio. Commentario breve al Codice di Procedura Civile. Padova: CEDAM, 1984.

CARSON, Hampton L. The history of the Supreme Court of the United States with all the Chief and Associate Justices. Philadelhia: P. W. Ziegler, 1891. v. 1.

CARVALHO, Nelson Rojas. Origens do Estado de bem-estar social: uma leitura conservadora. Arché, n. 16, 1997.

CASTELLS, Antoni; BOSCH, Núria (Coords.). El futuro del estado del bienestar. Madrid: Civitas, 1998.

CASTRO, Carlos Roberto Siqueira. A Constituição aberta e os direitos fundamentais: ensaios sobre o constitucionalismo pós-moderno e comunitário. Rio de Janeiro: Forense, 2005.

CATINELLA, Salvatore. La Corte Suprema Federale nel sistema costituzionale degli Stati Uniti d'America. Padova: CEDAM, 1934.

CHIEFFI, Lorenzo. La magistratura: origine del modello costituzionale e prospettive di riforma. Napoli: Casa Editrice Dott. Eugenio Jovene, 1998.

CHIOVENDA, Giuseppe. Instituzioni di diritto processuale civile: i concetti fondamentali, la dottrina delle azioni. 2. ed. Napoli: Casa Editrice Dott. Eugenio Jovene, 1960. v. 1.

Principios de derecho procesal civil. Trad. José Casais y Santaló. Madrid: Reus, 2000. t. 1. 
CHIOVENDA, Giuseppe. Saggi di diritto processuale civile. Roma: Società Editrice "Foro Italiano", 1930.

CINTRA, Antonio Carlos de Araújo; DINAMARCO, Cândido Rangel; GRINOVER, Ada Pellegrini. Teoria geral do processo. 8. ed. São Paulo: Ed. Revista dos Tribunais, 1991.

COMOGLIO, Luigi Paolo. Etica e tecnica del "giusto processo". Torino: G. Giappichelli, 2004.

La garanzia costituzionale dell'azione ed il processo civile. Padova: Cedam, 1970.

COMPARATO, Fábio Konder. A afirmação histórica dos direitos humanos. 3. ed. São Paulo: Saraiva, 2003.

. Ensaio sobre juízo de constitucionalidade de políticas públicas. Revista dos Tribunais, São Paulo, ano 86, n. 737, p. 11-22, mar. 1997.

. O papel do juiz na efetivação dos direitos humanos. In: DIREITOS humanos: visões contemporâneas. Associação Juízes para a Democracia. São Paulo: Associação Juízes para a Democracia, 2001.

Prestação, promoção e violação dos direitos econômicos, sociais e culturais: a responsabilidade do Estado no direito interno e no direito internacional. In: ENCONTRO BRASILEIRO DE DIREITOS HUMANOS, 1., São Paulo, 1999. São Paulo: Centro de Estudos da Procuradoria Geral do Estado, 2001. 246 p. (Série Eventos, 8).

CONAC, Gérard. Justice et Constitutions. In: CONAC, G.; DELPÉRÉE, F.; PACTET, P.; TURPIN, D. Constitution et justice. Tunis: Presses del L'Université des Sciences Sociales de Toulouse; Académie Internationale de Droit Constitutionnel, 1995.

CONIGLIO, Antonino. Osservazioni al Progetto Preliminare del Codice di Procedura Civile. Milano: Giuffrè, 1938.

CORREIA, Marcus Orione Gonçalves. Poder constitucional de ação, direitos sociais e Estado democrático de direito. 2000. Tese (Livre-Docência) - Faculdade de Direito, da Universidade de São Paulo, São Paulo, 2000.

COUNTRYMAN, Edwin. The Supreme Court of the United States: with a review of certain decisions relating to its appellate Power under the Constitution. New York: Matthew Bender \& Company, 1913.

COUTURE, Eduardo Juan. Fundamentos do direito processual civil. Trad. Rubens Gomes de Souza. São Paulo: Saraiva, 1946. 
COXE, Brinton. An essay on judicial power and unconstitutional legislation, being a commentary on parts of the Constitution of the United States. Philadelphia: Kay and Brother, 1893.

DAHRENDORF, Ralf. O conflito social moderno: um ensaio sobre a política da liberdade. Tradução de Renato Aguiar e Marco Antonio Esteves da Rocha. Rio de Janeiro; São Paulo: Jorge Zahar; EDUSP, 1992.

DALLARI, Dalmo de Abreu. Direitos humanos e cidadania. 2. ed. São Paulo: Moderna, 2004.

. Elementos de teoria geral do Estado. 26. ed. São Paulo: Saraiva, 2007.

. Palestra proferida Rio de Janeiro, em novembro de 2001. In: ANAIS DO SEMINÁRIO O SUPREMO TRIBUNAL FEDERAL NA HISTÓRIA DA REPUBLICANA. Brasília, DF: AJUFE, 2002.

O poder dos juízes. São Paulo: Saraiva, 1996.

A violação dos direitos econômicos, sociais e culturais e seu impacto no exercício dos direitos civis e políticos. In: ENCONTRO BRASILEIRO DE DIREITOS HUMANOS, 1., São Paulo, 1999. São Paulo: Centro de Estudos da Procuradoria Geral do Estado, 2001. 246 p. (Série Eventos, 8).

DAMAŠKA, Mirjan R. I volti della giustizia e del potere: analisi comparatistica del processo. Bolonha: Il Mulino, 2002.

DARRIGRANDE SILVA, Jorge. Los derechos humanos en America. Santiago de Chile: Editorial Jurídica de Chile, 1969.

DAVID, René. Os grandes sistemas do direito contemporâneo. Trad. Hermínio A. Carvalho. São Paulo: Martins Fontes, 1998.

DE LA TORRE RANGEL, Jesús Antonio. Sobre el origen de la tradición hispanoamericana de los derechos humanos. Revista da Faculdade de Direito da Universidade Federal do Paraná, Curitiba, n. 29, 1996.

DENTI, Enrico; VELLANI, Mario. Diritto processuale civile: nozioni e rogole generali. 5. ed. Milano: Giuffrè, 2000. v. 1.

Profili civilistici della tutela degli interessi diffusi. In: STANZANI, Davide; FIORE, Adriano (a cura di). Strumenti per la tutela degli interessi diffusi della collettività. Rimini: Maggioli, 1982.

DE RUGGIERO, Guido. Storia del liberalismo Europeo. 5. ed. Bari: Laterza, 1949. 
DERBI, Felipe. A aplicabilidade do princípio da proibição do retrocesso social no direito brasileiro. In: SOUZA NETO, Cláudio Pereira de; SARMENTO, Daniel (Coords.). Direitos sociais: fundamentos, judicialização e direitos sociais em espécie. Rio de Janeiro: Lumen Juris, 2008.

DI PIETRO, Maria Sylvia Zanella. Direito administrativo. 13. ed. São Paulo: Atlas, 2001.

DINAMARCO, Cândido Rangel. Fundamentos do processo civil moderno. 2. ed. São Paulo: Ed. Revista dos Tribunais, 1987. Instituições de direito processual civil. São Paulo: Malheiros Ed., 2001. v. 1 e v. 2. . A instrumentalidade do processo. 8. ed. São Paulo: Malheiros Ed., 2000.

DRAIBE, Sônia M. As políticas sociais e o neoliberalismo: reflexões suscitadas pelas experiências latino-americanas. Revista USP, São Paulo, n. 17, p. 86-101, mar/maio 1993.

DROMI, Roberto. El Poder Judicial. Buenos Aires: Ediciones Ciudad Argentina, 1996.

DUARTE, Clarice Seixas. $O$ direito público subjetivo ao ensino fundamental na Constituição Brasileira de 1988. 2003. Tese (Doutorado) - Faculdade de Direito, Universidade de São Paulo, São Paulo, 2003.

DUFOUR, Alfred. Droits de l'homme, droit naturel et historie. Paris: Press Universitaires de France, 1991.

DWORKIN, Ronald. Taking rights seriously. Cambrige: Massachusetts, 1978.

Une question de principe. Traduzido do inglês por Aurélie Guillain, A matter of principle. Paris: Presses Universitaires de France, 1996.

EISSEN, Marc-André. El Tribunal Europeo de Derechos Humanos. Madrid: Civitas, 1985. $175 \mathrm{p}$.

ELJATIB, Axel. Kant, Hegel y el principio del fin del derecho natural. Crítica Jurídica: revista latinoamericana de política, filosofia y derecho, n. 22, 2003.

ERNST, Carlos. Independencia judicial y democracia. In: MALEM, Jorge; OROZCO, Jesús; VÁZQUEZ, Rodolfo (Coords.). La función judicial: ética y democracia. Barcelona: Gedisa, 2003.

FAGUET, Emile. La politique comparée de Montesquieu, Rousseau et Voltaire. Paris: Société Français d'Imprimerie et de Librairie, 1902.

FAGUNDES, Miguel Seabra. O controle dos atos administrativos pelo Poder Judiciário. 7. ed. Rio de Janeiro: Forense, 2006. 
FARIA, Carlos Aurelio Pimenta de. Uma genealogia das teorias e modelos do Estado de bem-estar social. BIB: revista da Anpocs, n. 46, 1998.

FARIA, José Eduardo. Introdução: o Judiciário e o desenvolvimento sócio-econômico. In: (Org.). Direitos humanos, direitos sociais e justiça. São Paulo: Malheiros Ed., 2005.

- O Poder Judiciário no Brasil: paradoxos, desafios e alternativas. Brasília: Conselho da Justiça Federal, 1995.

FERRAZ JUNIOR, Tercio Sampaio. Introdução ao estudo do direito: técnica, decisão, dominação. São Paulo: Atlas, 1988.

. O Judiciário frente à divisão dos poderes: um princípio em decadência? Revista USP, São Paulo, n. 21, p. 12-21, mar./maio 1994.

FERREIRA FILHO, Manoel Gonçalves. Curso de direito constitucional. 34. ed. São Paulo: Saraiva, 2008.

Direitos humanos fundamentais. 9. ed. São Paulo: Saraiva, 2007.

FIX-ZAMUDIO, Hector. La proteccion juridica y procesal de los derechos humanos ante las jurisdicciones nacionales. México: Civitas, 1982.

FREIRE JÚNIOR, Américo Bedê. O controle judicial de políticas públicas. In: BEDAQUE, José Roberto dos Santos; CRUZ E TUCCI, José Rogério (Coords). Temas fundamentais de direito. São Paulo: Ed. Revista dos Tribunais, 2005. v. 1.

GARGARELLA, Roberto. Democracia deliberativa e o papel dos juízes diante dos direitos sociais. In: SOUZA NETO, Cláudio Pereira de; SARMENTO, Daniel (Coords.). Direitos sociais: fundamentos, judicialização e direitos sociais em espécie. Rio de Janeiro: Lumen Juris, 2008.

GARZÓN VALDÉS, Ernesto. El papel del poder judicial em la transición a la democracia. In: MALEM, Jorge; OROZCO, Jesús; VÁZQUEZ, Rodolfo (Coords.). La función judicial: ética y democracia. Barcelona: Gedisa, 2003.

GONÇALVES, William Couto. Gênese dos direitos humanos na antiga filosofia grega. Rio de Janeiro: Lumen Juris, 2007.

GRAU, Eros Roberto. O direito posto e o direito pressuposto. 7. ed. São Paulo: Malheiros Ed., 2008.

GREENE, Theodore Meyer. Liberalismo: teoria e prática. Tradução de Leonidas Gotijo de Carvalho. São Paulo: Ibrasa, 1968. 
GRIFFITH, John Aneurin Grey. The politics of the Judiciary. 4. ed. London: Fontana, 1991.

GRINOVER, Ada Pellegrini. A ação civil pública no STJ. Revista de Processo, São Paulo, ano 25 , jul./set. 2000.

. Ações coletivas ibero-americanas: novas questões sobre a legitimação e a coisa julgada. Revista Forense, Rio de Janeiro, v. 361, p. 3, maio/jun. 2002.

A defesa do meio ambiente em juízo como conquista da cidadania. CEJ - Revista de Estudos do Conselho da Justiça Federal, Brasília, n. 9, set./dez. 1999.

Deformalização do processo e deformalização ds controvérsias. Revista de Processo, São Paulo, ano 12, n. 46, p. 60-61, abr./jun. 1987.

Direito processual coletivo. In: GRINOVER, Ada Pellegrini; MENDES, Aluisio Gonçalves de Castro; WATANABE, Kazuo (Coords.). Direito processual coletivo e o anteprojeto de Código Brasileiro de Processos Coletivos. São Paulo: Ed. Revista dos Tribunais, 2007.

As garantias constitucionais do direito de ação. São Paulo: Ed. Revista dos Tribunais, 1973.

O magistério de Enrico Tullio Liebman no Brasil. Revista da Associação dos Juízes do Rio Grande do Sul, Porto Alegre, ano 14, p. 80-83, 1987.

Modernidade do direito processual brasileiro. In: $O$ processo em evolução. Rio de Janeiro: Forense, 1996.

Mudanças estruturais no processo civil brasileiro. Revista IOB de Direito Civil e Processual Civil, Porto Alegre, ano 8, n. 44, p. 35-55, nov./dez. 2006).

. Os princípios constitucionais e o Código de Processo Civil. São Paulo: Bushatsky, 1975.

A problemática dos interesses difusos. In: (Coord.). A tutela dos interesses difusos. São Paulo: Max Limonad, 1984.

A responsabilidade do juiz brasileiro. In: Estudos de direito processual em homenagem a José Frederico Marques. São Paulo: Saraiva, 1982.

. Relatório Geral - Civil Law: os processos coletivos nos países de civil law. In: GRINOVER, Ada Pellegrini; WATANABE, Kazuo; MULLENIX, Linda. Os processos coletivos nos países de civil law e common law: uma análise de direito comparado. São Paulo: Ed. Revista dos Tribunais, 2008. 
GUARNIERI, Carlo; PEDERZOLI, Patrizia. The power of judges: a comparative study of courts and democracy. Oxford; New York: Oxford University Press, 2003.

HABSCHEID, Walter J. Introduzione al diritto processuale civile comparato. Rimini: Maggioli, 1985.

HALLOWELL, John. Decline of liberalism as an ideology: with particular reference to german politico-legal thought. London: Kegan Paul, Trench, Trubner, 1946.

HAYDEN, Patrick. The philosophy of human rights. St. Paul, MN: Paragon House, 2001.

HERRERO DE MIÑÓN, Mighel. Nacionalismo y constitucionalismo: el derecho constitucional de los nuevos estados. Madrid: Tecnos, 1971.

HERSHBERG, Eric; JELIN, Elizabeth (Orgs.). Construindo a democracia: direitos humanos, cidadania e sociedade na América Latina. São Paulo: EDUSP, 2006.

HESSE, Konrad. A força normativa da Constituição. Trad. Gilmar Ferreira Mendes. Porto Alegre: Sergio Fabris, 1991.

HOBBES, Thimas. Leviatã. São Paulo: Rideel, 2005. Parte I, Capítulos XIII e XIV. (Biblioteca Clássica).

HUMAN Development Report. Disponível em: <http://hdr.undp.org/en/reports/research>.

ISHAY, Micheline R. The history of human rigths: from ancient times to the globalization era. Berkeley: University of California Press, 2008.

KELSEN, Hans. Teoria pura do direito. Trad. João Baptista Machado. São Paulo: Martins Fontes, 2000.

LA CHINA, Sergio. Manuale di diritto processuale civile: le disposizioni generali. Milano: Giuffrè, 2003. v. 1.

LAFER, Celso. Globalização econômica, políticas neoliberais e os direitos econômicos, sociais e culturais. ENCONTRO BRASILEIRO DE DIREITOS HUMANOS, 1., São Paulo, 1999. São Paulo: Centro de Estudos da Procuradoria Geral do Estado, 2001. 246 p. (Série Eventos, 8).

LAVIÉ, Quiroga. Los derechos públicos subjetivos y la participación social. Buenos Aires: Depalma, 1985.

LAWSON, Rick; BLOIS, Matthijs. The dynamics of the protection of human rights in Europe: essays in honour of Henry G. Schermers. Dordrecht; Boston; London: Martinus Nijhoff Publishers, 1994. v. 3, 416 p. 
LEONE, G. Potere Giudiziario e Corte di Garanzia Costituzionale. Appendici - I Projetti di Riforma. In: RIGANO, Francesco. Costituzione e Potere Giudiziario: ricerca sulla formazione delle norme costituzionali. Padova: Cedam, 1982.

LEPAULLE, Pierre. La justice. Paris: Payot, 1934.

LESSA, Pedro. Do Poder Judiciário. Ed. fac-similar. Brasília: Senado Federal, Conselho Editorial, 2003. (Coleção História constitucional brasileira).

LEWIS, John E. A documentary history of human rights: a record of the events, documents and speeches that shaped our world. New York: Carroll \& Graf Publishers, 2003.

LIEBMAN, Enrico Tullio. Diritto comune e processo civile brasiliano. In: STUDI in onore di Enrico Redenti nel XL anno del suo insegnamento. Milano: Giuffrè, 1951, v. 1.

LOCKE, John. Segundo Tratado sobre o Governo. São Paulo: Martin Claret, 2006. (Coleção Obra-Prima de Cada Autor).

LOPES, José Reinaldo de Lima. Direitos sociais: teoria e prática. São Paulo: Método, 2006.

. Em torno da "reserva do possível". In: SARLET, Ingo Wolfgang; TIMM, Luciano Benetti (Orgs.). Direitos fundamentais: orçamento e "reserva do possível". Porto Alegre: Livraria do Advogado, 2008.

Judiciário, democracia, políticas públicas. Revista de Informação Legislativa, Brasília, v. 31. n. 122, p. 255-265, abr./jun. 1994.

LOPEZ PINA, Antonio. La garantia constitucional de los derechos fundamentales. Alemania, España, Francia e Italia. Madrid: Civitas, 1991.

LOVELAND, Ian. Constitutional law, administrative law, and human rights: a critical introduction. 4. ed. Oxford: Oxford University Press, 2006.

LUCIUS, Pierre. Agonie du liberalisme. Paris: Sirey, 1938.

LUCON, Paulo Henrique dos Santos; GABBAY, Daniela Monteiro; ALVES, Rafael Francisco; ANDRADE, Tathyana Chaves de. Interpretação do pedido e da causa de pedir nas demandas coletivas (conexão, continência e litispendência). In: LUCON, Paulo Henrique dos Santos (Coord.). Tutela coletiva: 20 anos da Lei da Ação Civil Pública e do Fundo de Defesa de Direitos Difusos, 15 anos do Código de Defesa do Consumidor. São Paulo: Atlas, 2006.

LUHMANN, Niklas. I diritti fondamentali come istituzione. Trad. Stefano Magnolo. Bari: Dedalo, 2002. 
MANCUSO, Rodolfo de Camargo. A ação civil pública como instrumento de controle judicial das chamadas políticas públicas. In: MILARÉ, Édis (Coord). Ação civil pública: Lei 7.347/1985 - 15 anos. 2. ed. São Paulo: Ed. Revista dos Tribunais, 2002.

Ação popular: proteção do erário, do patrimônio público, da moralidade administrativa e do meio ambiente. 5. ed. São Paulo: Ed. Revista dos Tribunais, 2003. (Controle jurisdicional dos atos do Estado; v. 1/coord. Eduardo Arruda Alvim et al.).

A concomitância de ações coletivas, entre si, e em face das ações individuais. Revista da Faculdade de Direito da USP, São Paulo, v. 96, 2001.

MARITAIN, Jacques. Les droits de l'homme et la loi naturelle. Paris: Paul Hartmann, 1948.

McCRUDDEN, Christopher. A common law of human rights? transnational judicial conversations on constitutional rights. In: O'DONOVAN, Katherine; RUBIN, Gerry R. (Eds.). Human rights and legal history: essays in honour of Brian Simpson. New York: Oxford, 2004.

MEIRELLES, Hely Lopes. Direito administrativo brasileiro. 16. ed. São Paulo: Ed. Revista dos Tribunais, 1991.

MELlO, Celso Antônio Bandeira de. Curso de direito administrativo. 18. ed. São Paulo: Malheiros Ed., 2005.

MENDES, Aluisio Gonçalves de Castro. Ações coletivas no direito comparado e nacional. São Paulo: Ed. Revista dos Tribunais, 2002.

MENDES, Gilmar Ferreira; COELHO, Inocêncio Mártires; BRANCO, Paulo Gustavo Gonet. Curso de direito constitucional. São Paulo: Saraiva, 2007.

MIRANDA, Francisco Cavalcanti Pontes de. Comentários à Constituição de 1967, com a Emenda $n^{\circ}$ 1, de 1969. 2. ed. São Paulo: Ed. Revista dos Tribunais, 1974. t. 5.

MONTESANO, Luigi; ARIETA, Giovanni. Diritto processuale civile: le disposizioni generali. 2. ed. Torino: G. Giappichelli, 1996. v. 1.

MONTESQUIEU, Charles de Secondat, Baron de. O espírito das leis. Trad. Pedro Vieira Mota. 9. ed. São Paulo: Saraiva, 2008.

MORANGE, Jean. Droits de l'homme et libertés publiques. 5. ed. Paris: Puf, 1985.

MOREIRA, José Carlos Barbosa. A proteção jurisdicional dos interesses coletivos ou difusos. In: GRINOVER, Ada Pellegrini (Coord.). A tutela dos interesses difusos. São Paulo: Max Limonad, 1984. 
MORTARA, Lodovico. Instituzioni di procedura civile. Firenze: S. A. G. Barbèra, 1937.

NABAIS, José Casalta. A face oculta dos direitos fundamentais: os deveres e os custos dos direitos. Revista de Direito Público da Economia, ano, 5, n. 20, p. 153-181, out./dez. 2007.

NADER, Paulo. Filosofia do direito. 13. ed. Rio de Janeiro: Forense, 2003.

NEQUETE, Lenine. O Poder Judiciário no Brasil: crônica dos tempos coloniais. Brasília: Supremo Tribunal Federal, 2000. v. 1 e v. 2.

NERY JÚNIOR, Nelson. Mandado de segurança coletivo. Revista de Processo, São Paulo, ano 15, n. 57, ano 15, p. 151, jan./mar. 1990.

Princípios do processo civil na Constituição Federal. 6. ed. São Paulo: Ed. Revista dos Tribunais, 2000.

NOVAIS, Jorge Reis. As restrições aos direitos fundamentais não expressamente autorizadas pela Constituição. Coimbra: Coimbra Ed., 2003.

NUNES, José de Castro. Teoria e prática do Poder Judiciário. Rio de Janeiro: Revista Forense, 1943.

O'BRIEN, David M. Constitutional law and politics: civil rights and civil liberties. 6. ed. New York: Norton, 2005. v. 2.

OESTREICH, Gerhard. Storia dei diritti umani e delle liberta fondamentali. Bari: Laterza, 2001.

PEDRAZ PENALVA, Ernesto. Constitucion, jurisdiccion y proceso. Madrid: Akal, 1990.

PELLETAN, Eugène. Droits de l'homme. 12. ed. Paris: Pagnerre, 1858.

PELLOUX, Robert (Coord.). Essais sur les droits de l'homme em Europe. Torino: G. Giappichelli, 1959. 180 p.

LA PENSÉE politique et constitutionelle de Montesquieu: bicentenaire de l'Esprit des lois, 1748-1948. Université de Paris. Institut de Droit Compare. Paris: Recueil Sirey, 1952.

PEREZ LUÑO, Antonio E. Los derechos fundamentales. Madrid: Tecnos, 1984.

PINA, Rafael; CASTILLO LARRAÑAGA, Jose. Instituciones de derecho procesal civil. 10. ed. México: Porrua, 1974.

PIOVESAN, Flávia. A Constituição Brasileira de 1988 e os tratados internacionais de proteção dos direitos humanos. In: DIREITOS humanos: visões contemporâneas. Associação Juízes para a Democracia. São Paulo: Associação Juízes para a Democracia, 2001. 
PIOVESAN, Flávia. Direitos humanos e o direito constitucional internacional. 8. ed. São Paulo: Saraiva, 2007.

Direitos humanos e justiça internacional. São Paulo: Saraiva, 2006.

PIZZORNO, Alessandro. Il potere dei giudici: Stato democratico e controllo della virtù. Roma: Laterza, 1998.

POUILLE, André. Le pouvoir judiciaire et les tribunaux. Paris: Masson, 1985.

POURTOIS, Hervé. Démocratie délibérative et droits fondamentaux. In: COUTU, Michel; BOSSET, P.; GENDREAU, C.; VILlENEUVE, D. (Dirs.). Droits fondamentaux et citoyenneté: une citoyenneté fragmentée, limitée, illusoire? Montréal: Thémis, 1999.

PRONUNCIAMENTO do Ministro Enéas Galvão. In: PACHECO, Felix. A Independência do Poder Judiciário e as prerrogativas do Supremo Tribunal Federal. Rio de Janeiro: Typ. do "Jornal do Commercio", de Rodrigues \& C., 1913.

PUFENDORF, Samuel. On the duty of man and citizen according to natural law. Trad. de Michael Silverthorne. Cambridge: Cambridge University Press, 1991.

PUGLIA, Ferdinando. Il diritto nella vita economica. Messina: Carmelo de Stefano Ed., 1885.

REALE, Miguel. Filosofia do direito. 19. ed. São Paulo: Saraiva, 2002.

RÉGOLI, Hervé. Institutions judiciaires. 2. ed. Paris: Dalloz, 1999. 233 p.

RENOUX, Thierry. Le Conseil Constitutionnel et l'autorite judiciaire: l'élaboration d'ún droit constitutionnel juridictionnel. Paris: Economica, 1984.

REQUEJO PAGÉS, Juan Luis Requejo. Jurisdiccion e independencia judicial. Madrid: Centro de Estudios Constitucionales, 1989. (Colección Estudios Constitucionales).

REZEK, José Francisco. Direito internacional público: curso elementar. 6. ed. São Paulo: Saraiva, 1996.

RIGANO, Francesco. Costituzione e potere giudiziario: ricerca sulla formazione delle norme costituzionali. Padova: Cedam, 1982. 315 p.

RIPAMONTI, Cristian Bulnes. Relaciones y conflictos entre los organos del Poder Estatal. Chile: Editorial Jurídica de Chile, 1967.

ROBERTSON, David. Judicial discretion in the house of lords. Oxford: Clarendon Press, 1998. 
ROCHA, José de Albuquerque. Estudos sobre o Poder Judiciário. São Paulo: Malheiros Ed., 1995.

ROUSSEAU, Félicien. L'avenir dês droits humains. Canadá: Les Presses de l'Université Laval, 1996. 380 p.

ROUSSEAU, Jean Jacques. O contrato social. São Paulo: Martin Claret, 2008. Livro II. (Coleção Obra-Prima de Cada Autor).

RUINI, Meuccio. La nostra e le cento costituzioni del mondo: problemi aperti: Organi Costituzionali. Milano: Giuffrè, 1964.

RUIZ MIGUEL, Carlos. La ejecución de lãs sentencias del Tribunal Europeo de Derechos Humanos. Madrid: Tecnos, 1997. 183 p.

SALAZAR, Alcino. Poder Judiciário. Rio de Janeiro: Forense, 1975.

SALDANHA, Nelson. Estado moderno e o constitucionalismo. São Paulo: Bushatsky, 1976.

SALLES, Carlos Alberto de. Ação civil pública contra omissões do poder público: limites e possibilidades. In: (Org.). Processo civil de interesse público: o processo como instrumento de defesa social. São Paulo: Ed. Revista dos Tribunais; Associação Paulista do Ministério Público, 2003.

SANCHES VIAMONTE, Carlos. Constitucionalismo: sus problemas. Buenos Aires: Bibligrafica Argentina, 1957.

SANTOS, Marília Lourido dos. Interpretação constitucional no controle judicial das políticas públicas. Porto Alegre: Sergio Antonio Fabris, 2006.

SARLET, Ingo Wolfgang. A eficácia dos direitos fundamentais. 9. ed. Porto Alegre: Livr. do Advogado, 2008.

SCHWAB, Karl Heinz. El objeto litigioso en el proceso civil. Trad. Tomas A. Banzhaf Der Streitgegenstand im Zivilprozess. Buenos Aires: Ediciones Juridicas Europa-America, 1968.

SHETREET, Shimon; DESCHÊNES, Jules. Judicial Independence: the contemporary debate. Dordrecht: Martinus Nijhoff Publishers, 1985. 700 p.

SHUE, Henry. Basic rights: subsistence, affluence and US foreign policy, Princeton: Princeton University Press, 1980.

SILVA, José Afonso da. Aplicabilidade das normas constitucionais. 3. ed. São Paulo: Malheiros Ed., 1998. 
SILVA, José Afonso da. Curso de direito constitucional positivo. 24. ed. São Paulo: Malheiros Ed., 2005.

- Governabilidade num Estado democrático. In: VALADÉS, Diego (Coord.). Governabilidad y constitucionalismo em América Latina. México: Unam, 2005.

SILVA, Luis Virgílio Afonso da. O conteúdo essencial dos direitos fundamentais e a eficácia das normas constitucionais. Tese (Titularidade) - Faculdade de Direito, Universidade de São Paulo, São Paulo, 2005.

O Judiciário e as públicas: entre transformação social e obstáculo à realização dos direitos fundamentais. In: SOUZA NETO, Cláudio Pereira de; SARMENTO, Daniel (Coords.). Direitos sociais: fundamentos, judicialização e direitos sociais em espécie. Rio de Janeiro: Lumen Juris, 2008.

STOTZKY, Irwin P. Creating the conditions for democracy. In: KOH, Harold Hongju; SLYE, C. (Eds.). Deliberative democracy \& human rights. New Haven and London: Yale University Press, 1991.

STRAUSS, Leo. Liberalismo antico e moderno. Milano: Giuffrè, 1973.

STRECK, Lenio Luiz. O papel da jurisdição constitucional na realização dos direitos sociais-fundamentais. In: SARLET, Ingo Wolfgang (Org.). Direitos fundamentais sociais: estudos de direito constitucional, internacional e comparado. Rio de Janeiro: Renovar, 2003.

SUNSTEIN, Carl; HOLMES, Stephen. The cost of rights: why liberty depends on taxes. New York: Norton, 1999. 235 p.

SWEET, Alec Stone. Governing with judges: constitutional politics in Europe. Oxford: Oxford University Press, 2000.

The judicial construction of Europe. New York: Oxford, 2004.

TARUFFO, Michele. La motivazione della sentenza civile. Padova: CEDAM, 1975.

TASSARA, Andrés Ollero. 50 Anos da Declaração Universal dos Direitos Humanos: o significado dos direitos fundamentais. Revista de Direito Constitucional e Internacional, São Paulo, ano 11, n. 43, p. 57-72, abr./jun. 2003.

TAVARES, André Ramos. Curso de direito constitucional. 6. ed. São Paulo: Saraiva, 2008.

TELLES JUNIOR, Goffredo da Silva. A criação do direito. 2. ed. São Paulo: Juarez de Oliveira, 2004. 
TELlES JUNIOR, Goffredo da Silva. Direito quântico: ensaio sobre o fundamento da ordem jurídica. 7. ed. São Paulo: Juarez de Oliveira, 2003.

Ética: do mundo da célula ao mundo dos valores. 2. ed. São Paulo: Juarez de Oliveira, 2004.

. Tratado da consequência: curso de lógica formal. 6. ed. São Paulo: Juarez de Oliveira, 2003.

TIMOTHEO, Pedro. O Poder Judiciário sob a nova Constituição da República. [s.l.]: [s.e.], 1939.

TOCQUEVILLE, Aléxis de. A democracia na América. 2. ed. Belo Horizonte: Itatiaia. São Paulo: EDUSP, 1977.

TOYNBEE, Arnold. A humanidade e a mãe-terra. 2. ed. Rio de Janeiro: Zahar, 1982.

TRENDELENBURG, Adolfo. Diritto naturale sulla base dell'etica. Napoli: Jovene, 1873.

TRINDADE, Antônio Augusto Cançado. O Sistema Interamericano de Direitos Humanos no limiar do novo século: recomendações para o fortalecimento de seu mecanismo de proteção. In: A PROTEÇÃO INTERNACIONAL DOS DIREITOS HUMANOS E O BRASIL. WORKSHOP. Brasília, 7-8 out. 1999. Brasília: Superior Tribunal de Justiça, 2000.

TROCKER, Nicolò. Processo civile e constituzione: problemi di diritto tedesco e italiano. Milano: Giuffrè, 1974.

TUCK, Richard. Natural rights theories: their origin and development. Cambridge: Cambridge University Press, 1979.

VALE, Osvaldo Trigueira do. O Supremo Tribunal Federal e a instabilidade políticoinstitucional. Rio de Janeiro: Civilização Brasileira, 1976.

VARAUT, Jean-Marc. Le droit au juge. Paris: Quai Voltaire, 1991.

VARELA, Casimiro A. Fundamentos constitucionales del derecho processual. Buenos Aires: AD-Hoc, 1999.

VARELA FEIJÓO, Jacobo. La proteccion de los derechos humanos: jurisprudencia de la Comision Y Tribunal Europeo de Derechos del Hombre. Barcelona: Editorial Hispano Europea, 1972. 372 p.

VIALLE, Pierre. La Cour Supreme et la representation politique aux Etats-Unis: nouvel essai sur le gouvernement des juges. Paris: Librairie Générale de Droit et de Jurisprudence, 1972. 
VIEIRA, Oscar Vilhena. Supremo Tribunal Federal: jurisprudência política. São Paulo: Ed. Revista dos Tribunais, 1994.

VIGORITI, Vicenzo. Interessi collettivi e processo: la legittimazione ad agire. Milano: Giuffrè, 1979.

WATANABE, Kazuo. Acesso à justiça na sociedade moderna. In: GRINOVER, Ada Pellegrini; DINAMARCO, Cândido Rangel; WATANABE, Kazuo. Participação $e$ processo. São Paulo: Ed. Revista dos Tribunais, 1988.

Da cognição no processo civil. São Paulo: Ed. Revista dos Tribunais, 1987.

Processo civil de interesse público: introdução. In: SALLES, Carlos Alberto (Org.). Processo civil de interesse público: o processo como instrumento de defesa social. São Paulo: Ed. Revista dos Tribunais; Associação Paulista do Ministério Público, 2003. Relação entre demanda coletiva e demandas individuais. Revista de Processo, São Paulo, v. 31, n. 139, p. 28-35, set. 2006.

Tutela antecipatória e tutela específica das obrigações de fazer e não fazer: arts. 273 e 461 do CPC. Ajuris: revista da Associação dos Juízes do Rio Grande do Sul, Porto Alegre, v. 23, n. 66, p. 160-161, mar. 1996.

Tutela jurisdicional dos interesses difusos: a legitimação para agir. In: GRINOVER, Ada Pellegrini (Coord.). A tutela dos interesses difusos. Coord. Ada Pellegrini Grinover. São Paulo: Max Limonad, 1984.

ZAFFARONI, Eugenio Raúl. Poder Judiciário: crise, acertos e desacertos. Trad. Juarez Tavares. São Paulo: Ed. Revista dos Tribunais, 1995. 